\title{
INFIDELIDADE VIRTUAL - REALIDADE COM EFEITOS JURÍDICOS ${ }^{1}$
}

\author{
VIRTUAL INFIDELITY - REALITY WITH LEGAL EFFECTS
}

\author{
Laura de Toledo Ponzoni ${ }^{2}$
}

\begin{abstract}
Resumo:
O escopo principal do artigo é a caracterização e configuração jurídica da Infidelidade Virtual. O Direito de Família depara-se com essa nova questão, que vem suscitando muitos debates. A própria prática profissional já demonstra a existência de diversos relacionamentos iniciados pela Internet. A temática é introduzida por uma breve referência à família e ao casamento, passando-se à discussão do adultério e da infidelidade, onde são testadas as etimologias dos vocábulos "adultério", "infidelidade" e "deslealdade", que provocam certa confusão na doutrina. Em seguida, inicia-se o estudo sobre o dever de fidelidade, a caracterização do adultério e do quase-adultério (injúria grave), fazendo-se também referência ao dever de lealdade. No tocante à culpa, faz-se uma breve menção à aplicação deste instituto no Direito de Família, que tem gerado diversas controvérsias, em especial na quebra dos deveres dos cônjuges. Ainda com o intuito de familiarizar o leitor com a temática proposta, desenvolve-se um breve estudo sobre a Internet e suas noções básicas de funcionamento. Em capítulo próprio, busca-se caracterizar o novo instituto da Infidelidade Virtual, expondo-se as principais discussões existentes a respeito. Também se faz menção à possibilidade de aplicação dos danos morais no tema ora tratado. Por fim, busca-se imprimir um aspecto mais prático neste artigo, abordando-se as principais questões processuais que ele envolve, de forma a orientar os operadores do Direito que eventualmente irão se deparar com o assunto. Portanto, é profunda a convicção de que a Infidelidade Virtual encerra uma realidade com efeitos jurídicos.
\end{abstract}

Palavras-chave: Infidelidade Virtual. Internet. Dever de Fidelidade. QuaseAdultério. Deslealdade. Culpa. Danos Morais. Aspectos Processuais.

\begin{abstract}
:
The main purpose of the article is the characterization and legal configuration of virtual infidelity. The Family Law faces this new subject, which has raised lots of discussion. The profissional practice demonstrates the existence of several relationships initiated on the Internet. The theme is introduced by a brief reference for family and marriage, followed by a discussion of the adultery and infidelity, where it is tested the etimology of the words "adultery", "infidelty" and "disloyalty" - which provoke certain confusion in the doctrine. Next, a study about fidelty duty, the characterization of adultery and the so called "almost-adultery" (serious insult) is
\end{abstract}

\footnotetext{
1 A presente análise é fruto de estudos realizados na elaboração da Tese de Láurea com o mesmo título, apresentada no ano de 2006, perante o Departamento de Direito Civil da Faculdade de Direito da Universidade de São Paulo e uma das indicadas, pelo respectivo departamento, para o Prêmio "Jovem Jurista" de 2006. A consecução deste trabalho seria impossível sem o auxílio inestimável do orientador Professor Titular Álvaro Villaça Azevedo.

2 Advogada, bacharel pela Faculdade de Direito da Universidade de São Paulo, doutoranda em Direito Civil na mesma instituição, sob orientação da Professora Associada Teresa Ancona Lopez.
} 
iniciated, with reference also to loyalty duty. About the guilt, a brief mention of the aplication of this institute in the Family Law, that has produced some controversy, specially in the rupture of the spouse duties, is done. Still with the intuite of familiarizing the reader with the proposed theme, a brief study on the Internet and some basic functioning notions are desenvolved. In an opportune chapter, we intend to characterize the new institute of the Virtual Infidelity, revealing some of the main discussion existing on this respect. It is also mentioned the possibility of application of the moral injury on this theme. Ultimately, we try to print a more practical aspect in this article, broaching the main legal proceedings that it wraps, in a way of orienting the Law operatings which eventualy come across this subject. Therefore, we have a deep conviction that the Virtual Infidelty is a reality with legal effects.

Keywords: Virtual Infidelty. Internet. Fidelity Duty. "Almost-Adultery". Disloyalty. Guilt. Moral Injury. Legal Proceedings.

Prefácio

A infidelidade virtual é uma realidade que invade domicílios conjugais, com comprovados efeitos na vida matrimonial. É nossa profunda convicção de que a temática que nos propomos dissecar encerra uma realidade social, cada vez mais relevante e que, por isso, merece a atenção dos juristas, na busca de uma valoração jurídica. Trata-se de um tema que aguça o espírito das pessoas e provoca as mais diversas reações.

Algumas questões dissecadas neste artigo poderão causar estupefação aos leitores menos familiarizados com o tema proposto. Talvez o que mais impressione seja a facilidade com que esses relacionamentos ocorrem, sendo cada vez mais comuns em nossa sociedade. De onde se pode concluir que a afetividade humana pode se revestir das mais variadas formas.

Não pretendemos realizar nenhum tipo de juízo de valor neste estudo; por isso, nos limitamos a apontar essa nova realidade, suas principais características e efeitos provocados nos diversos relacionamentos. Também não buscamos ser conclusivos; ao contrário, nosso objetivo mais modesto foi apontar alguns possíveis caminhos para as questões nascidas do novel fenômeno.

Estamos atentos às controvérsias existentes, principalmente por tratar-se de um tema recente e pouco explorado pela doutrina. Muitas dúvidas ainda irão surgir.

Esperamos atingir os objetivos a que nos propomos, trazendo um artigo inovador do ponto de vista jurídico, mas principalmente útil aos operadores do Direito. 
1. Introdução

1.1 A família

O Direito de Família é o ramo mais sensível da Ciência do Direito, pois lida com pessoas nos momentos em que estão mais fragilizadas, mexe com seus sentimentos, afetos e perdas.

Muitas questões geram grande impacto no espírito popular e aguçam a perspicácia dos sociólogos, moralistas, escritores, religiosos e juristas, o que evidencia que o Direito de Família, mais do que qualquer outra disciplina, presta-se ao debate e à controvérsia.

Os estudos do Direito de Família revestem-se de peculiaridades não encontradas em nenhum outro campo do Direito, pois versam sobre objeto que a ordem jurídica não pode disciplinar inteiramente, quer em razão da sua própria natureza, quer pelo caráter complexo das suas relações. É muito difícil engessar nas normas jurídicas as vivências de cada um, seus amores e desamores. Assim, nas questões jurídicas que envolvem a família, a compreensão mais aprofundada e a solução adequada só serão alcançadas se considerarmos os fatores emocionais envolvidos. ${ }^{3}$

Conforme nos ensina Sílvio de Salvio Venosa, "a família é um dado natural, uma realidade social que preexiste ao Direito. Seus fundamentos repousam prioritariamente em princípios de base sociológica que o ordenamento transforma em jurídicos". 4

Importante lembrar que "a partir da concepção de família como uma estruturação psíquica, podemos entendê-la como o núcleo básico, fundante e essencial de qualquer sociedade ou agrupamento humano",5 por isso ela tem direito à especial proteção do Estado. ${ }^{6}$

O Direito de Família contemporâneo - e o Direito Civil como um todo - não pode distanciar-se da legalidade constitucional, impondo-se estrita obediência às premissas fundamentais postas na Magna Carta, que consistem nos valores mais relevantes

3 Cf. MOTTA, Maria Antonieta Pisano. Além dos fatos e dos relatos: uma visão psicanalítica do direito de família. In: II CONGRESSO BRASILEIRO DE DIREITO DE FAMÍLIA - IBDFAM. A família na travessia do milênio. Belo Horizonte: Del Rey, 2000. p. 39-52.

4 VENOSA, Sílvio de Salvio. Direito civil: direito de família. 3. ed. São Paulo: Atlas, 2003. v. 6, p. 145.

5 PEREIRA, Rodrigo da Cunha. A culpa no desenlace conjugal. In: NAZARETH, Eliana Riberti; MOTTA, Maria Antonieta Pisano (Coords.). Direito de família e ciências humanas: Caderno de Estudos n. 3. São Paulo: Jurídica Brasileira, 2000. p. 133-153.

6 Art. 226 Constituição Federal: “A família, base da sociedade, tem especial proteção do Estado”. 
da ordem jurídica brasileira, sendo o valor mais precioso, erigido como fundamental pela Constituição Federal, de 1988, a dignidade da pessoa humana, que impõe a elevação do ser humano ao ápice de todo o sistema jurídico. ${ }^{7}$

Portanto, o Direito de Família brasileiro sofreu radicais mudanças nas últimas décadas, culminando na Constituição Federal, de 1988, que proclamou a igualdade do homem e da mulher nos direitos e obrigações (art. $5^{\circ}$, inc. I) ${ }^{8}$ e impôs que os direitos e deveres referentes à sociedade conjugal são por eles exercidos igualmente (art. $\left.226, \S 5^{\circ}\right){ }^{9}$ Desse reconhecimento decorrem importantes conseqüências, e essa tendência foi seguida pelo Código Civil. Fundamental ressaltar que, com a afirmação dos valores humanitários, o Direito de Família passou a estar induvidosamente calcado na afetividade. ${ }^{10}$

Entretanto, a família ainda sofre enormes e profundas modificações. Doutrina e jurisprudência tentam acompanhar essas evoluções nas relações familiares, enquanto o conjunto de normas, ordenado para possibilitar a coexistência social, muitas vezes está voltado a um sistema ultrapassado. ${ }^{11}$

\footnotetext{
7 O Estado está cada vez mais atento à dignidade da pessoa como ser humano. O cidadão deixou de ser mero partícipe de uma estrutura chamada de base da sociedade. A família serve de complemento, de apoio, e não deve subjugar seus integrantes a uma entidade sacralizada. Nesse sentido, DIAS, Maria Berenice. Era uma $v e z . .$. In: IV CONGRESSO BRASILEIRO DE DIREITO DE FAMÍLIA - IBDFAM. Afeto, ética, família e o novo código civil. Belo Horizonte: Del Rey, 2004. p. 13-16. p. 18.

$\mathrm{O}$ reconhecimento da dignidade humana impõe nova postura aos civilistas modernos (especialmente àqueles que laboram com o Direito de Família), devendo, na interpretação e aplicação de normas e conceitos jurídicos, assegurar a vida humana de forma integral e prioritária. Nesse sentido, FARIAS, Cristiano Chaves de. Redesenhando os contornos da dissolução do casamento (casar e permanecer casado: eis a questão). In: IV CONGRESSO BRASILEIRO DE DIREITO DE FAMÍLIA - IBDFAM. Afeto, ética, família e o novo código civil. Belo Horizonte: Del Rey, 2004. p. 105-126.

8 “Art. $5^{\circ} .(\ldots)$

I - homens e mulheres são iguais em direito e obrigações, nos termos desta Constituição".

9 “Art. 226. (...)

$\S 5^{\circ}$ Os direitos e deveres referentes à sociedade conjugal são exercidos igualmente pelo homem e pela mulher".

${ }^{10}$ A família abandonou seu caráter de instituição jurídica e passou a merecer tutela como verdadeiro instrumento de afirmação da realização pessoal do ser humano. Assim ela deixou de ser fim e passou a ser meio, instrumento. Descobriu-se que as pessoas não nascem com o fim especifico de constituir família, mas, ao revés, nascem voltadas para a busca de sua felicidade e realização pessoal, como conseqüência lógica da afirmação da dignidade do homem. É a partir desse impostergável direito de ser feliz que se edifica uma nova concepção de família, informada por laços afetivos, de carinho e amor.

${ }^{11}$ Nesse sentido, SANTOS, Regina Beatriz Tavares Silva Papa dos. Responsabilidade civil dos cônjuges. In: II CONGRESSO BRASILEIRO DE DIREITO DE FAMÍLIA - IBDFAM. A família na travessia do milênio. Belo Horizonte: Del Rey, 2000. p. 121-140.
} 
Nas palavras de Yussef Said Cahali, "há uma convicção generalizada de que a familia moderna passa por uma crise profunda". ${ }^{12} \mathrm{Na}$ realidade, nas relações familiares se vê com maior nitidez as conseqüências que as aceleradas mudanças sociais provocam no comportamento humano. ${ }^{13}$

As estruturas culturais são condicionadas a conceitos que sofrem mutações difíceis de acompanhar. A família está vivendo um momento psicológico delicado. Geralmente são os restos do amor que batem às portas do Judiciário. ${ }^{14}$

Apesar de todas as transformações e "crises" da família, ela traz consigo elementos essenciais que atravessam o tempo e o espaço: é o núcleo formador da pessoa e fundador do sujeito. Como dito anteriormente, ela é o núcleo básico e ordenador da sociedade, por isso subsiste às mudanças históricas e políticas da humanidade, redesenhando seu contorno através dos tempos e persistindo na função de sua estrutura inabalável, responsável pela constituição do sujeito e pela transmissão da cultura. ${ }^{15}$

${ }^{12}$ CAHALI, Yussef Said. Divórcio e separação. 10. ed. São Paulo: Revista dos Tribunais, 2002. p. 18.

Na opinião de Jacques de Camargo Penteado: “a crise não é jurídica. É da família. O Direito não pode ignorar a crise da família”. (PENTEADO, Jacques de Camargo. A família e a justiça penal, In: II CONGRESSO BRASILEIRO DE DIREITO DE FAMÍLIA - IBDFAM. A família na travessia do milênio. Belo Horizonte: Del Rey, 2000. p. 353-363.).

Falamos hoje em crise das instituições, por exemplo da própria família. A família chega a ser vista por alguns como em via de extinção. É verdade que nos sentimos ameaçados pelas mudanças. Mas as crises são condições da existência da própria família. Nesse sentido, GROENINGA, Giselle Câmara. Direito e psicanálise: um novo horizonte epistemológico. In: IV CONGRESSO BRASILEIRO DE DIREITO DE FAMÍLIA - IBDFAM. Afeto, ética, família e o novo código civil. Belo Horizonte: Del Rey, 2004. p. 249-263.

13 Os pressupostos que formavam o que acreditávamos ser as bases de nosso conhecimento têm se modificado. Atualmente há uma perda de referenciais Outros pressupostos surgem em um horizonte em que crise é a palavra corrente. A crise é um estado de um sistema em que uma mudança é iminente.

${ }^{14}$ Não tendo capacidade para resolver seus próprios conflitos, as partes transferem a responsabilidade para um Juiz, na esperança de que ele venha apresentar a solução mais adequada. Nesse sentido, PEREIRA, Rodrigo da Cunha. A culpa no desenlace conjugal. cit., p. 137.

Nos dias de hoje, a mediação está se tornando um mecanismo indispensável, quase uma condição prévia para que a interferência do juiz, quando necessária, seja menos intervencionista, menos traumática.

${ }^{15}$ As famílias não permanecem imutáveis, mas ainda guardam uma série de resquícios culturais vinculados a tradições que antecedem aos atuais modelos legais. Nesse sentido, COLARES, Marcos A. P. O que há de novo no direito de família? In: II CONGRESSO BRASILEIRO DE DIREITO DE FAMÍLIA - IBDFAM. A família na travessia do milênio. Belo Horizonte: Del Rey, 2000. p. 315-323. 


\subsection{O Casamento}

Definir o casamento é uma missão árdua e complexa. Sua evolução na história se deu de diversas maneiras entre os diferentes povos, sendo nítidas, mesmo nos dias de hoje, essas diferenças. ${ }^{16}$

No início, prevaleciam nos diversos povos os relacionamentos poligâmicos. As tendências monogâmicas foram ocorrendo, sem condenação formal à poligamia. $\mathrm{Ou}$ seja, a monogamia ficou lado a lado com a poligamia desde a época arcaica e tendeu, pouco a pouco, a prevalecer. ${ }^{17}$

Nas palavras de Maria Berenice Dias, “a monogamia (...) não foi de modo algum um fruto do amor sexual individual, mas uma mera convenção decorrente do triunfo da propriedade privada sobre o condomínio espontâneo primitivo". ${ }^{18}$ Assim, a estrutura passou a ser monogâmica e patriarcal. As razões da mudança do antigo paradigma da família grupal para a família monogâmica parecem ter sido de ordem econômica. Seguramente essa mudança não se baseou no amor individual. ${ }^{19}$

Importante ressaltar que o matrimônio era, para a doutrina católica, instituto de Direito Divino Natural, nascido sob o ensinamento bíblico, como a íntima união do homem e da mulher para realizar a integração física e espiritual de ambos. ${ }^{20}$ Assim, no casamento canônico, que nascia da vontade dos nubentes, a cópula estava ligada à indissolubilidade do vínculo matrimonial. Ou seja, o casamento, uma vez contraído, permaneceria por toda a vida.

Hoje, com o casamento, união civil ou religiosa com efeitos civis entre homem e mulher, institui-se a família, considerada a base da sociedade.

\footnotetext{
${ }^{16}$ Na maioria dos países ocidentais prevalece nos ordenamentos a união monogâmica, entretanto, o casamento polígamo é atualmente admitido por diversos ordenamentos jurídicos de países muçulmanos.

${ }^{17}$ Nesse sentido, GAUDEMET, Jean. Institutions de l'antiquité. Paris: Sirey, 1967. p. 116-117; apud AZEVEDO, Álvaro Villaça. Estatuto da família de fato. 2. ed. São Paulo: Atlas, 2002. p. 33-34.

Conforme acentua Charles Letourneau, os hebreus foram os únicos, entre os semitas, a adotar a monogamia, pelo menos na prática geral, o que demonstra que a concubinagem não foi proibida pela Bíblia ao povo de Deus. LETOURNEAU, Charles. L'évolution du mariage et de la famille. Paris: Adrien Delahaye e Émile Lecrosnier, 1888. p. 234; apud AZEVEDO, Álvaro Villaça. op. cit., p. 34.

${ }_{18}$ DIAS, Maria Berenice. O dever de fidelidade. Disponível em: $<$ http://www.mundojuridico.adv.br/html/artigos/ documentos/texto224.htm> ou <http://editorial.locaweb.com.br/Seu Direito/Artigos/o_dever_de_fidelidade. $\mathrm{htm}>$. Acesso em: 16 maio 2005.

19 Cf. FIÚZA, César Augusto de Castro. Mudança de Paradigmas: do Tradicional ao Contemporâneo, In: II CONGRESSO BRASILEIRO DE DIREITO DE FAMÍLIA - IBDFAM. A família na travessia do milênio. Belo Horizonte: Del Rey, 2000. p. 27-38.

20 Segundo o texto bíblico, Deus, criando o homem e a mulher, à sua imagem, recomendando-lhes que fossem fecundos e que crescessem e se multiplicassem, determinou sua união em uma só carne, texto de que se serviu Jesus para defender o caráter indissolúvel do casamento monogâmico.
} 
Os fins do casamento são de ordem subjetiva, de foro íntimo, razão pela qual não estão determinados em lei. Porém, os efeitos jurídicos dessas uniões são as conseqüências previstas no ordenamento. ${ }^{21}$

Segundo alguns defensores do casamento, ele é o fundamento da sociedade, base da moralidade pública e privada. Já os críticos chegam a afirmar que casar é perder metade de seus direitos e duplicar seus deveres. ${ }^{22}$

Numa concepção de cunho individualista, Kant afirma que o casamento seria a união de duas pessoas para a posse mútua, durante toda a vida, de suas faculdades sexuais. ${ }^{23}$ Assim, o casamento teria por elemento decisivo a fidelidade.

Para Pontes de Miranda o matrimônio não se esgota como relação simplesmente jurídica, sendo antes, e acima de tudo, uma relação moral. ${ }^{24}$

Na realidade, "o casamento é mais que uma instituição religiosa e jurídica. Para a maior parte das pessoas é um sonho de felicidade" ${ }^{25}$ Ele continua sendo um ideal onde se depositam esperanças. Entretanto, alguns dados apontam um número crescente de separação de casais. ${ }^{26}$

“As relações conjugais são repletas de aspectos: sentimentais, religiosos, pessoais e patrimoniais, envolvendo duas pessoas num projeto grandioso, preordenado a durar para sempre. Mas nem sempre isso acontece. O sonho acaba, o amor termina;

\footnotetext{
${ }^{21}$ O Direito apenas dá normas e regula o instituto do casamento, daí resultam seus complexos efeitos, com direitos e deveres recíprocos para os cônjuges. Contenta-se a lei em apenas enunciar aqueles princípios que se consideram elementos indispensáveis ao matrimônio, e que, no seu conjunto, constituem a base fundamental da família.

"Importantes conseqüências ou efeitos advêm do casamento, apesar de se atenuar a relevância de épocas passadas e de preponderar como natural a sua temporariedade". RIZZARDO, Arnaldo. Direito de família. 2. ed. Rio de Janeiro: Forense, 2004. p. 167.

${ }^{22}$ Nesse sentido, SILVA, Regina Beatriz Tavares da. Débito conjugal. In: IV CONGRESSO BRASILEIRO DE DIREITO DE FAMÍLIA - IBDFAM. Afeto, ética, família e o novo código civil. Belo Horizonte: Del Rey, 2004. p. 531-541.

${ }^{23}$ Id. Ibid., p. 532.

É célebre a passagem de Kant, dizendo que o matrimônio confere ao nubente o direito exclusivo sobre os órgãos sexuais do cônjuge. Ele sustenta que o casamento é "um comércio sexual garantido por lei: um contrato com o fim particular, que é o uso dos membros e faculdades sexuais, atribuindo a cada um dos cônjuges um direito real sobre o corpo do outro". KANT, Immanuel. Principios metafisicos del derecho. Buenos Aires: Amerialee, 1943. p. 112 e ss; apud SILVA, Hugo Lança. O direito de família e a internet: infidelidade virtual: mito ou realidade com efeitos jurídicos. Lisboa: Verbojuridico, 2005. p. 5.

${ }^{24}$ MIRANDA, Francisco Cavalcanti Pontes de. Tratado de direito privado. Rio de Janeiro: Borsoi, 1955. v. 8, n. 843, p. 105.

${ }^{25}$ PEREIRA, Rodrigo da Cunha. A culpa no desenlace conjugal. cit., p. 137.

${ }^{26}$ A partir do final do século XX, tornaram-se corriqueiras as separações conjugais, as quais ocorrem pelos mais variados motivos, sendo certo, entretanto, que o principal deles é a infidelidade.
} 
o rompimento é inevitável, cabendo ao Direito oferecer instrumentos para reequilibrar a situação pessoal e patrimonial dos cônjuges". ${ }^{27}$

\section{Infidelidade}

\subsection{Evolução Histórica}

No decorrer do desenvolvimento das sociedades, o adultério sempre foi tema tratado com bastante relevância. Esta é uma questão tão antiga quanto a História. ${ }^{28}$

Por muito tempo, devido a uma mentalidade patriarcal, o adultério materializava uma conseqüência direta do direito absoluto de propriedade, agravada pelos impulsos de uma sexualidade agressiva e brutal, visando apenas ao alívio de uma tensão física, despida de qualquer sentimento afetivo, emotivo ou amoroso. ${ }^{29}$ Assim, “(...) $o$ adultério surgiu como um delito contra a propriedade, uma espécie de furto de uso ou de empréstimo, nunca como um crime ou uma afronta à honra conjugal, à família, aos bons costumes, ao sacramento, ao Estado". ${ }^{30}$

O que ocorreu, talvez, é que a monogamia ocidental só se sustentava pelo adultério. E este, a seu turno, se assentava no paradigma do patriarcalismo. ${ }^{31}$

Entretanto, desde Moisés, com a Lei das Doze Tábuas, temo-nos deparado com uma proibição, transformada em norma jurídica: "não cometerás adultério.” Assim, não se revestiam de pequena monta as sanções contra a quebra do dever de fidelidade conjugal, quando fazemos referência às normas bárbaras do antigo Direito. Percebe-se a maior veemência com que o adultério era punido antigamente, com castigos corporais, ainda que somente para as mulheres.

Dessa forma, Yussef Said Cahali sabiamente nos ensina que: "as relações matrimoniais frustradas, as decepções pós-matrimoniais, os desencantos e as derivações

\footnotetext{
27 SANTOS. Regina Beatriz Tavares da Silva Papa dos. Responsabilidade civil dos cônjuges. In: II CONGRESSO BRASILEIRO DE DIREITO DE FAMÍLIA - IBDFAM. A família na travessia do milênio. Belo Horizonte: Del Rey, 2000. p. 123.

${ }^{28}$ Nesse sentido, PEREIRA, Rodrigo da Cunha. Adultério virtual. Disponível em: <http://www.boletimjuridico. com.br/doutrina/impressao.asp?id=154>. Acesso em: 29 maio 2006.

${ }^{29}$ Nesse sentido, LIMA, Domingos Sávio Brandão. Adultério. In: FRANÇA, Rubens Limongi (Coord.). Enciclopédia Saraiva do Direito. São Paulo: Saraiva, 1977. v. 4, p. 448-470. p. 450.

${ }^{30}$ Id. Ibid., p. 451.

31 Cf. FIÚZA, César Augusto de Castro. op. cit., p. 35.
} 
em busca de novas aventuras ou de prazeres transitórios sempre existiram, aqui e acolá, em todos os tempos, com maior ou menor freqüência". ${ }^{32}$

\subsection{Deveres dos Cônjuges - Dever de Fidelidade}

Conforme valioso ensinamento de Goffredo Telles Junior, "a inteligência incorporou à natureza do ser humano o sentimento de dever, ou seja, o sentimento de que o ser humano deve comportar-se de acordo com determinados ideais". ${ }^{33} \mathrm{O}$ mesmo prossegue afirmando que "de fato, a ordenação ética ou moral é a ordenação composta de juizos de dever. Isto significa que essa ordenação é feita de mandamentos para o comportamento humano, em razão de um conjunto de anteriores juizos de valor". ${ }^{34}$

Com o casamento, o homem e a mulher formulam uma promessa de adesão aos deveres e às obrigações que a lei estabelece como necessários à consecução de seus fins essenciais.

A celebração do casamento cria deveres recíprocos que se impõem aos cônjuges como condição inafastável de sobrevivência da união conjugal. Os principais deveres foram dispostos no art. 1.566 do Código Civil, de 2002, a saber: fidelidade recíproca; vida em comum, no domicílio conjugal; mútua assistência; sustento, guarda e educação dos filhos; e respeito e consideração mútuos. O casamento estabelece outros deveres recíprocos aos cônjuges, mas a lei ateve-se aos mais importantes, reclamados pelo interesse social e pela ordem pública, considerados necessários para a estabilidade conjugal. ${ }^{35}$ No Código Civil, de 1916, os mesmos deveres eram previstos no art. 231. Apenas o último deles foi acrescentado pelo Código atual.

Assim, impõe-se uma gama de direitos e deveres iguais e recíprocos aos cônjuges, que constituem um regramento da vida em comum.

Em certos aspectos, pode-se afirmar que existe uma regulamentação excessiva. No entanto, em outros, figura-se como indispensável o estabelecimento de regras de conduta aos cônjuges, tendo em vista a manutenção do núcleo familiar, bem como a integridade física e moral de seus membros.

\footnotetext{
32 CAHALI, Yussef Said. Divórcio e separação. 10. ed. São Paulo: Revista dos Tribunais, 2002. p. 20.

33 TELLES JÚNIOR, Goffredo da Silva. Palavras do amigo aos estudantes de direito: bosquejos extracurriculares, proferidos no escritório do professor, em 2002. São Paulo: Juarez de Oliveira, 2003. p 68.

34 TELLES JÚNIOR, Goffredo da Silva. Palavras do amigo aos estudantes de direito: bosquejos extracurriculares, proferidos no escritório do professor, em 2002. São Paulo: Juarez de Oliveira, 2003. p. 70-71.

35 Nesse sentido, GONÇALVES, Carlos Roberto. Sinopses Jurídicas: direito de família. São Paulo: Saraiva, 1997. v. 2, p. 45 e SOARES, Orlando. Direito de família. Rio de Janeiro: Forense, 2004. p. 272.
} 
Entretanto, a imposição desses deveres não permite a quaisquer dos cônjuges o desrespeito e a violação da esfera individual do outro. A liberdade individual lhes é assegurada, de modo que lhes são permitidos cultuar sua fé, ter suas convicções e opções políticas etc. ${ }^{36}$ Essas limitações aos deveres, de fato, traduzem-se mais num complemento de sua plenitude, posto que a cada um é reservado o direito de realizar-se como pessoa no casamento. ${ }^{37}$

É imprescindível que o ordenamento jurídico estabeleça as conseqüências do descumprimento dos deveres conjugais, sob pena de tais deveres se tornarem meras recomendações, sem qualquer sanção por sua violação. ${ }^{38}$ Assim, a infração de cada um desses deveres constitui causa para a separação judicial.

Portanto, a imposição de deveres aos cônjuges tem a finalidade de assegurar a harmonia no casamento e o alcance pelos consortes da tão almejada felicidade. ${ }^{39} \mathrm{Na}$ sábia lição de Yussef Said Cahali, "tais direitos e deveres fundam-se não só nas leis como nos princípios do bem-agir (...)". ${ }^{40}$

Cumpre esclarecer que a verificação do que se conceitua como dever, e a configuração do seu descumprimento, há de ser feita através da análise do caso concreto, conhecendo-se substancialmente a relação existente entre o casal.

São inúmeras as hipóteses em que violações a deveres do casamento acarretam danos às pessoas envolvidas nessas relações. Para o escopo específico deste artigo, interessam-nos especialmente as violações ao dever de fidelidade.

A fidelidade traduz-se por uma constância no querer, pela atitude que leva ao cumprimento rigoroso de promessas, deliberações e contratos. ${ }^{41}$ Porém, é no âmbito da

\footnotetext{
${ }^{36} \mathrm{O}$ ordenamento jurídico impõe restrições à liberdade dos cônjuges no tocante à liberdade sexual, em razão da fidelidade que devem guardar os cônjuges. No entanto, ela deve ser preservada e respeitada nas demais questões.

${ }^{37}$ Nesse sentido, FACHIN, Luiz Edson; RUZYK, Carlos Eduardo Pianovski. Direito de família. Casamento. In: AZEVEDO, Álvaro Villaça (Coord..). Código civil comentado. São Paulo: Atlas, 2003. v. 15, p. 208.

${ }^{38}$ SANTOS, Regina Beatriz Tavares Silva Papa dos. Responsabilidade civil dos cônjuges. In: II CONGRESSO BRASILEIRO DE DIREITO DE FAMÍLIA - IBDFAM. A família na travessia do milênio. Belo Horizonte: Del Rey, 2000. p. 125.

${ }^{39}$ Id. Ibid.,p. 132.

${ }^{40}$ CAHALI, Yussef Said. Divórcio e separação. 10. ed. cit., p. 58.

41 "A fidelidade é uma exigência ética universal e irrenunciável que tem sua origem no Direito natural. Trata-se de uma forma particular de justiça. Todo relacionamento humano depende dela. Traz a idéia de estabilidade, de transparência e de reciprocidade”. PENTEADO, Jacques Camargo. op. cit., p. 359.
} 
família que a estipulação adquire conotação mais acentuada, estando inclusos os princípios éticos, jurídicos, sociais e religiosos. ${ }^{42}$

O dever moral e jurídico de fidelidade mútua é o corolário da família monogâmica admitida por nossa sociedade. ${ }^{43}$ Portanto, ele decorre do caráter monogâmico do casamento, sendo exigido em nome dos superiores interesses da sociedade e constitui um dos alicerces da vida conjugal e da família matrimonial. ${ }^{44}$

Conforme nos ensina Clóvis Bevilaqua: "sintoma do amor recíproco, que deve acalentar o diuturno da vida comum entre marido e mulher, a lei o exige em nome dos interesses superiores da sociedade; coloca-se, assim, como o mais importante dos deveres, a expressão natural da monogamia". ${ }^{45}$

Desde os primórdios da instituição do casamento, sempre se manteve este importante dever, que praticamente é seu pressuposto. A mútua fidelidade é, portanto, a pedra angular do instituto do casamento, e tal obrigação promana da índole do próprio vínculo. $^{46}$

Assim, o dever de fidelidade pode ser entendido como a dedicação recíproca e exclusiva dos cônjuges, assentes na lealdade e sinceridade, e como decorrência lógica do mesmo surge o impedimento dos cônjuges terem relações sexuais com terceiros. ${ }^{47}$

Como dito anteriormente, impõe-se o dever de fidelidade a ambos os cônjuges, em igual medida e força jurídica. ${ }^{48}$ Antigamente o Código fazia diferenciação, punindo mais gravemente a conduta da mulher adúltera. ${ }^{49}$

${ }^{42}$ Cf. CAHALI, Yussef Said. Adultério e desquite. 1972. 292 p. Tese (Livre-docência) - Faculdade de Direito, Universidade de São Paulo, São Paulo. p. 1.

${ }^{43}$ O imperativo da união monogâmica encontra-se implícita ou explicitamente realçado nas legislações dos diversos povos. É esse dever dos cônjuges, de se manterem fiéis ao compromisso de um pertencer só ao outro, com exclusividade.

${ }^{44}$ Nesse sentido, DINIZ, Maria Helena. Curso de direito civil brasileiro: direito de família. 17. ed. São Paulo: Saraiva, 2002. v. 5, p. 123.

${ }^{45}$ BEVILAQUA, Clóvis. Código civil. 10. ed. Rio de Janeiro: Paulo Azevedo, 1954. v. 2, p. 87.

${ }^{46}$ Sua origem e causa de existir estão na organização da própria família, e revela uma tendência natural do ser humano, que não admite, neste campo, uma coexistência de relações sexuais com múltiplas pessoas, representando um dos sustentáculos básicos da unidade familiar. Cf. RIZZARDO, Arnaldo. op. cit., p. 170.

${ }^{47}$ Cf. SILVA, Hugo Lança. op. cit., p. 10.

${ }^{48}$ Nesse sentido, FACHIN, Luiz Edson; RUZYK, Carlos Eduardo Pianovski. op. cit., p. 207. O Código Penal também não fazia distinção entre o adultério de um e do outro cônjuge.

49 A mulher poderia engravidar de suas relações sexuais fora do lar e introduzir um filho bastardo dentro da vida conjugal. Assim, o horror ao adultério da mulher encontrava razão mais forte do que a mera injúria moral, sendo caracterizado com apenas uma infração ao dever de fidelidade; enquanto o adultério do homem não se manifestava, a não ser que o marido mantivesse manceba teúda e manteúda. Ou seja, o homem era punido quando sua conduta fosse reiterada, somente quando ele mantivesse um caso extramatrimonial, o 
Podemos afirmar, portanto, que o dever de fidelidade recíproca emana do matrimônio civil. ${ }^{50}$ Assim, cada cônjuge renuncia à sua liberdade sexual, já que a fidelidade supõe exclusividade do débito conjugal, uma plena comunhão de vida. Concebida deste modo, ocorre a violação do dever de fidelidade conjugal quando qualquer dos cônjuges estabelece com um terceiro um relacionamento idêntico ao que é possível estabelecer com o outro cônjuge. Cabem aqui, portanto, a conjunção carnal ou uma mera ligação amorosoplatônica com um estranho, conforme se verá mais adiante.

Dessa forma, a fidelidade recíproca é dever de conteúdo negativo, pois exige uma abstenção de conduta, que é a regra da exclusividade. A ordem jurídica não se limita a impor aos cônjuges o dever de convivência plena, ela exige a dedicação recíproca e exclusiva de corpos. Trata-se, portanto, de uma prestação negativa: a abstenção de relações sexuais com pessoa que não o cônjuge. É um dever implícito ao próprio vínculo, uma obrigação de não-fazer. ${ }^{51}$

Concluímos que, dentre os deveres do casamento o que maior valor recebe em nossa cultura é a fidelidade recíproca. Sem o dever de mútua fidelidade, o vínculo matrimonial perde o seu sentido, trazendo graves efeitos sociais, além das conseqüências legais. ${ }^{52}$

chamado concubinato. Nesse sentido, RODRIGUES, Silvio. Comentários ao código civil: direito de família - casamento. São Paulo: Saraiva, 2003. v. 17, p. 125.

"Sempre foi muito tolerada a infidelidade sexual masculina, a ponto do dever de fidelidade ser relativo para o homem e absoluto para a mulher, tradicionalmente posta em situação de inferioridade". MADALENO, Rolf. A infidelidade e o mito causal da separação. Disponível em: <http://editorial.locaweb.com.br/SeuDireito/ Artigos/a_infidelidade_eo_mito_causal.htm>. Acesso em: 17 maio 2005

50 Como conseqüência da unicidade do vínculo, o respeito à fidelidade não pode ser postergado mediante pacto antenupcial ou convenção posterior, tendente a estabelecer a liberdade de um ou de ambos os cônjuges. Cf. CAHALI, Yussef Said. Divórcio e separação. 10. ed. cit., p. 59.

Será ineficaz a estipulação, pois afronta disposição absoluta da lei, representando uma ofensa aos bons costumes e superiores interesses sociais.

Assim, também, a infidelidade de um dos cônjuges não pode ser invocada pelo outro para justificar a própria infidelidade. Trata-se de dever que não pode ser dispensado, mas se a falta é perdoada pelo outro cônjuge deixa de ser justa causa para a separação. Nesse sentido, GOMES, Orlando. Direito de família. 12. ed. Rio de Janeiro: Forense, 2000. p. 136.

${ }^{51}$ É um direito cujo adimplemento não pode ser exigido em juízo. Não se tem notícia de ter sido proposta, na constância do casamento, demanda que busque o cumprimento de tal dever. De que forma poderia ser executada a sentença que impusesse a abstinência sexual extramatrimonial ao demandado? Nesse sentido, DIAS. Maria Berenice. O dever de fidelidade. Disponível em: $<$ http://www.mundojuridico.adv.br/html/artigos/ documentos/texto224.htm ou http://editorial.locaweb.com.br/Seu Direito/Artigos/o_dever_de_fidelidade. $\mathrm{htm}>$. Acesso em: 16 maio 2005.

52 "A fidelidade não é um valor entre outros, uma virtude entre outras: ela é aquilo por que, para que há valores e virtudes. Que seria a justiça sem a fidelidade dos justos? A paz, sem a fidelidade dos pacíficos? A liberdade, sem a fidelidade dos espíritos livres? E que valeria a própria verdade sem a fidelidade dos verídicos. (...) Não há virtude sem fidelidade". COMTE-SPONVILLE, André. Pequeno tratado das grandes virtudes. São Paulo: Martins Fontes, 1999. 


\subsection{Adultério é Sinônimo de Infidelidade?}

Para melhor compreendermos o tema, é necessário fazer uma digressão a respeito da etimologia de vocábulos "adultério", "infidelidade" e "deslealdade", e assim testar seus conceitos.

Conforme dispõe o Dicionário Aurélio de Lingua Portuguesa, adultério é a "infidelidade conjugal; prevaricação; união destoante, aberrante". Sendo o adúltero aquele que "violou ou viola a fidelidade conjugal". 53

A infidelidade é a "qualidade ou caráter de infiel; procedimento de infiel, deslealdade, traição, perfidia". ${ }^{54}$ A pessoa infiel é aquela desleal, traiçoeira, pérfida; que não cumpre aquilo a que se obrigou ou se obriga, impontual; aquela que não tem a fé considerada a verdadeira. Portanto, infidelidade seria a traição da fé conjugal. ${ }^{55}$

Também dispõe o Dicionário Aurélio que deslealdade é a falta de lealdade; falsidade; traição; e traição seria sinônimo de perfídia, deslealdade, aleivosia, "infidelidade no amor". A pessoa pérfida é aquela que "mente à fé jurada; fementido; traidor; desleal; infiel". 56

Assim, a primeira dúvida que surge é se adultério seria sinônimo de infidelidade..$^{57}$

Como se pode perceber, esses conceitos giram em torno dos mesmos elementos, e infelizmente não são muito esclarecedores do ponto de vista semântico, à medida que continuamos sem saber qual o alcance do conceito de adultério, e o que exatamente configura a infidelidade.

\footnotetext{
53 FERREIRA, Aurélio Buarque de Holanda. Novo Dicionário da Língua Portuguesa. 2. ed., 13. impr. Rio de Janeiro: Nova Fronteira, 1986.

${ }^{54}$ Id. Ibid.

55 "O termo fiel possui origem latina (fidele). Como adjetivo a palavra assume significado de probo; verdadeiro; firme. Enquanto substantivo feminino, fidelidade é sinônimo de lealdade e firmeza". COLARES, Marcos. Onde mora a (in)fidelidade? In: NAZARETH, Eliana Riberti; MOTTA, Maria Antonieta Pisano (Coords.). Direito de Família e Ciências Humanas: Caderno de Estudos n. 2. São Paulo: Jurídica Brasileira, 1998. p. 183-196. p. 183.

Têm-se como sinônimos de fidelidade os termos lealdade, honradez, honestidade, integridade, pontualidade, constância, firmeza, perseverança, entre outros. Nesse sentido, GARCIA, Carolina Ribeiro. O dever de fidelidade no casamento e na união estável e suas possíveis conseqüências. Disponível em: <http://www1. jus.com.br/doutrina/imprimir.asp?id=5222>. Acesso em: 16 maio 2005.

${ }^{56}$ FERREIRA, Aurélio Buarque de Holanda. op. cit.

"Creio que seja possível concluirmos que, ao nível do senso comum, infidelidade é sinônimo de traição". COLARES, Marcos. op. cit., p. 185.

${ }^{57}$ O Dicionário Caldas Aulete expressamente dispõe adultério como sinônimo de infidelidade conjugal. AULETE, Caldas. Dicionário Contemporâneo de Língua Portuguesa. 3. ed. Rio de Janeiro: Delta, 1978. v. 1 e 3 .
} 
Buscamos o conceito em outros dicionários: "Adultério. violação da fidelidade conjugal; relações carnais de pessoa casada com outra que não o seu cônjuge". ${ }^{58}$ "Adultério - Violação do matrimônio. Ato sexual entre pessoas que já estavam ligadas a outrem pelo vínculo matrimonial". 59

Cabe também dispor os conceitos encontrados em dicionários jurídicos: "Adultério. 1. Direito Civil. Relação sexual entre uma pessoa casada e outra que não seja o seu cônjuge, constituindo uma infração ao dever recíproco de fidelidade, desde que haja voluntariedade de ação e consumação da cópula carnal propriamente dita. É causa de ação de separação judicial litigiosa (...)". "Adúltero. Aquele que violou o dever de fidelidade conjugal, por ter tido relação sexual com terceiro". "Infidelidade conjugal. 1. Direito Civil. Transgressão por qualquer dos cônjuges do dever recíproco de fidelidade, decorrente do caráter monogâmico do casamento. Prática por um dos consortes de relação sexual com terceiro". 60 "Adultério. Crime contra o casamento tipificado quando qualquer dos cônjuges mantém conjunção carnal com um terceiro (...) Verifica-se o adultério pelo fato de qualquer dos cônjuges ter relações sexuais com outro homem (sendo a mulher) ou outra mulher (sendo o marido)" ${ }^{61}$

Por fim, buscamos auxílio em línguas estrangeiras. O dicionário italiano dispõe: “Adultèrio. Violazione dell'obbligo di fedeltà coniugale. Tresca, amore illecito o contro natura / fornicazione". ${ }^{2}$ Já na língua inglesa encontramos os seguintes conceitos: "Adultery. 1. The sexual intercourse of two persons, either of whom is married to a third person; unchastity; unfaithfulness". ${ }^{63}$ "Adultery. 1. Violation of the marriage bed; the voluntary sexual intercourse of a married person with one of the opposite sex, whether unmarried, or married to another" ${ }^{64}$ Por fim, encontramos o conceito de adultério no dicionário de língua espanhola: "Adulterio. Ayuntamiento carnal ilegítimo de hombre con mujer, siendo uno de los dos o ambos casados". ${ }^{65}$

\footnotetext{
58 FREIRE, Laudelino. Grande e Novíssimo Dicionário da Língua Portuguesa. 3. ed. Rio de Janeiro: Livraria José Olympio, 1957. v. 1.

59 BUENO, Francisco da Silveira. Grande Dicionário Etimológico-Prosódico da Língua Portuguesa. São Paulo: Saraiva, 1963. v. 1 e 4.

${ }^{60}$ DINIZ, Maria Helena. Dicionário Jurídico. São Paulo: Saraiva, 1998. v. 1 e 2.

${ }^{61}$ ACQUAVIVA, Marcus Cláudio. Dicionário Acadêmico de Direito. São Paulo: Jurídica Brasileira, 1999.

${ }^{62}$ ZINGARELLI, Nicola. Il Nuovo Zingarelli - Vocabolario Della Língua Italiana. 11. ed. Bologna: Zanichelli. 1990.

${ }^{63}$ FUNK \& WAGNALLS. Britannica World Language Dictionary. Chicago: New York, 1963. v. 1, parte 1.

${ }^{64}$ MURRAY, James A. H.;BRADLEY, Henry. The Oxford English Dictionary. Oxford, 1933. v. 1.

${ }^{65}$ SALVAT.Diccionario Enciclopédico Salvat. 2. ed. Barcelona: Salvat Editores, 1945. tomo 1.
} 
Como se pôde perceber, nestes conceitos surge um novo elemento para configurar o adultério: a relação carnal, cópula ou ato sexual. Sendo que a palavra infidelidade está mais relacionada à infração do dever recíproco dos cônjuges.

É importante esclarecer que muitos desses conceitos foram formulados à época em que o adultério era tipificado no Código Penal, ${ }^{66}$ por isso se verifica um nítido caráter de crime. No tema por nós proposto, importam os conceitos dos vocábulos para o Direito Civil, ainda mais se levarmos em consideração que o crime de adultério foi recentemente retirado do Código Penal. ${ }^{67}$

Cabe lembrar que o Código Civil, de 2002, o Código Civil, de 1916, e o Código Penal, bem como a generalidade das legislações, não se preocuparam em especificar o conceito de adultério ou o conteúdo do dever de fidelidade. ${ }^{68}$

Entretanto, a doutrina não tem encontrado dificuldades, apontando de maneira quase uniforme seus elementos constitutivos. Para alguns, "é a própria palavra enunciativa do instituto que traz ínsita a sua exata conceituação, seu conteúdo jurídico, sem necessitar de quaisquer explicações auxiliares para o seu entendimento" ${ }^{69}$

Nas palavras de Carrara, "a etimologia que comumente nos dão os autores da palavra adultério - ad alterius torum ire (andar em leito alheio) - se bem que desde o ponto de vista histórico e gramatical seja muito menos que exata, sem dúvida expressa suficientemente o conceito geral do fato em forma figurada, i.e., a violação do leito conjugal". ${ }^{70}$

O adultério, lesão maior, contunde e perturba de maneira mais profunda a vida familiar. Cuidando da etimologia do vocábulo, ${ }^{71}$ pode-se afirmar que deriva de $a d$

\footnotetext{
${ }^{66}$ Tão significativa era a imposição desse dever que a própria lei penal consagrava o adultério como delito, podendo levar à prisão do cônjuge infiel.

${ }^{67}$ A Lei n. 11.106, de 28 de março de 2005, revogou o art. 240 do Código Penal que estabelecia o crime de adultério. Assim, o adultério, tipificado na relação sexual do cônjuge com terceira pessoa, deixou de ter a punição penal. Note-se que tal artigo já era "letra morta", sendo praticamente inaplicável, há anos, a condenação do adultério na órbita penal.

${ }^{68}$ O Código Penal Brasileiro não descrevia qual a conduta desempenhada pelo agente que caracterizava o adultério, simplesmente denominava-lhe e cominava pena.

"Nosso Código guardou silêncio quanto ao conceito do crime, preferindo deixar como vigorante a intuição popular, derivada da própria etimologia por demais expressiva". LIMA, Domingos Sávio Brandão. op. cit., p. 455.

${ }^{69}$ LIMA, Domingos Sávio Brandão. op. cit., p. 449.

${ }^{70}$ CARRARA, F. Programa de Derecho Criminal. § 1.871. Bogotá: Temis, 1969. v. 3, t. 5/271, ; apud LIMA, Domingos Sávio Brandão. op. cit., p. 449.

71 "O vocábulo adultério não encontra uniformidade na sua origem, entretanto seu sentido é inequívoco. Usualmente, expressa ajuntamento carnal ilegítimo de homem com mulher, onde um dos dois ou ambos são casados”. LIMA, Domingos Sávio Brandão. op. cit., p. 449.
} 
alterum ire, mudando o "A" em "U" fez-se adulter. Tal vocábulo sempre teve a mesma significação, ir ao leito de outro, embora também empregado como sinônimo estuprum, que significava qualquer relação sexual com mulher casada ou viúva de honrada condição social. Alguns ligam o vocábulo à frase ad alterum torum ire, ou ao verbo adulterare, que significa corromper. ${ }^{72}$

Portanto, objetivamente considerado, o adultério é a conjunção carnal entre duas pessoas de sexo diferente, uma das quais, pelo menos, vinculada a um terceiro pelo laço matrimonial. ${ }^{73}$ Consiste, assim, na união sexual com pessoa outra que não o cônjuge, ou no fato de um dos cônjuges manter relações sexuais, completas e não-tentadas, com terceira pessoa.

A rigor seria difícil conceituar o adultério,${ }^{74}$ pois os atos constitutivos de tal infração podem apresentar-se com gravidade variada, desde a posse sexual plena com pessoa estranha, até os atos menos expressivos de sua preparação. ${ }^{75}$ Assim, caso não se configure o adultério, poder-se-ia configurar a injúria-grave. ${ }^{76}$

Assim, alguns autores afirmam que o adultério seria sinônimo de infidelidade, enquanto outros pregam que seria uma espécie de infidelidade, tratando-se de uma conduta mais grave, entre outras que configuram o quase-adultério, mas geram os mesmos efeitos. A diferença principal seria a confirmação da conjunção carnal, ou cópula, com pessoa estranha ao relacionamento conjugal, tratando-se, neste caso, de adultério. Se não houvesse tal prova, estaria confirmado o quase-adultério, outra forma de infidelidade, em que houve uma tentativa ou atos tendentes à finalização do feito.

Cabe apontar que a doutrina e jurisprudência cível não se preocupa com estes pormenores. ${ }^{77}$ Qualquer que seja, portanto, a etimologia que lhe é atribuída, certo é

${ }^{72}$ Cf. CAHALI, Yussef Said. Adultério e desquite. 1972. 292 p. Tese (Livre-docência) - Faculdade de Direito, Universidade de São Paulo, São Paulo. p. 7.

${ }^{73}$ Id. Ibid., p. 67.

74 “(...) seu conceito não pode ser considerado pacífico entre os diversos povos e sua caracterização se torna sumamente difícil pelas múltiplas peculiaridades com que se costuma camuflar, dependendo, em sua apreciação e prova, das diversas circunstâncias". LIMA, Domingos Sávio Brandão. op. cit., p. 450.

75 Cf. CAHALI, Yussef Said. Adultério e desquite. 1972. Tese (Livre-docência) - Faculdade de Direito, Universidade de São Paulo, São Paulo. p. 6.

${ }^{76}$ Atos lascivos ou libidinosos, a simples fornicatio comprometedores da fidelidade, fatos que ofendem a integridade moral ou atos puramente preparatórios a um momento supremo, embora possam fundamentar a injúria grave, não são constitutivos do adultério, por faltar-lhe o elemento físico. “(...) desde que o contato seja libidinoso ou consistir na prática comum ou insual de um amor fisiológico". LIMA, Domingos Sávio Brandão. op. cit., p. 462-463.

${ }^{77}$ Com a descriminalização do adultério, essa palavra perdeu um pouco de seu sentido original, fortemente relacionado ao conceito de crime. Para o direito civil, portanto, importa o sentido de transgressão do dever conjugal. "O adultério é apenas e tão-só infração civil em face do aspecto contratual do casamento, às 
que a palavra exprime, na linguagem jurídica e do cotidiano, um conceito caracterizado pelo rompimento do dever conjugal de fidelidade, pela prática de ato sexual com terceiro. Trata-se da quebra dessa fidelidade, essencial ao matrimônio.

Além disso, a ofensa ou violação ao dever de fidelidade, atualmente, segundo a maior parte da doutrina, deve ter interpretação mais abrangente. Em outros termos, o dever de fidelidade não se limita à abstenção do encontro sexual com estranho.

Como visto, o assunto tem dado margem a largas controvérsias. Porém, muito embora não-esteja definido nas diversas legislações contemporâneas, inclusive na nossa, seu conceito nasce de outras preceituações.

Preferimos adotar o conceito disposto no dicionário Houaiss, ${ }^{78}$ que está mais de acordo com a nossa realidade, e reúne os diversos elementos dispostos anteriormente: “Adultério. 1. violação, transgressão da regra de fidelidade conjugal imposta aos cônjuges pelo contrato matrimonial, cujo princípio consiste em não se manter relações carnais com outrem fora do casamento. 2. infidelidade estabelecida por relação carnal com outro(a) parceiro(a) que não o(a) companheiro(a) habitual". "Adúltero. que viola a fidelidade conjugal ao manter relação amorosa fora do casamento. pessoa que comete adultério, mantendo relações carnais com alguém fora do casamento". "Infidelidade. falta de respeito, de fidelidade àquilo com que se deveria estar comprometido. manutenção de ligações amorosas com outra pessoa diferente daquela com quem se está comprometido".

Diante do exposto, entendemos que a melhor forma de configurar o assunto por nós desenvolvido, seria com o vocábulo "infidelidade", que não exige a necessidade da cópula ou conjunção carnal, como o "adultério".

Para tanto, adotamos o conceito de infidelidade disposto no Dicionário Houaiss. Assim, podemos dizer que a infidelidade virtual consiste justamente nessas "ligações amorosas" com pessoa diferente daquela com quem se está comprometido, o que será explorado mais adiante.

condições impostas, por lei, para a sua caracterização. Não se trata de mensurá-lo, dosá-lo ou dissecá-lo para aferir-se qual a conseqüência mais perigosa do homem ou a da mulher”. LIMA, Domingos Sávio Brandão. op. cit., p. 461.

Há quem afirme que "O vocábulo adultério, depois de examinado à luz de sua etimologia, analisado sob as lentes reveladoras da história e pesquisado em sua melhor tipificação criminal, não mais precisa de conceituações e definições para um entendimento mais circunstanciado em nosso direito civil". Id. Ibid., p. 460.

${ }^{78}$ HOUASS, Antonio. Dicionário Houaiss da Língua Portuguesa. 1. ed. Rio de Janeiro: Objetiva, 2001. 


\subsection{Adultério e Quase-Adultério (Injúria-Grave)}

Diante dos conceitos anteriormente mencionados, surgem novos, que também necessitam ser explorados para um melhor entendimento deste trabalho.

Em frase muito expressiva empregada por Yussef Said Cahali, "o adultério é o matrimônio em crise" 79. Assim, "o adultério, antes de ser pecado, crime ou infração civil, é um sintoma de uma grave crise conjugal de proporções imensuráveis, falta de amadurecimento no relacionamento ou o simples desejo pelas multiplicidades proibidas". ${ }^{80}$

A comunidade e o Estado tornaram o adultério a maior transcendência das infrações contra a honestidade conjugal, não-só porque geralmente leva consigo uma carga de grave escândalo, como pela perturbação que provoca no seio da família e da sociedade. ${ }^{81}$

Nas palavras de Silvio Rodrigues: "o adultério representa séria ameaça à vida conjugal, pois não raro ao cônjuge ofendido repugnará o convívio com o adúltero. Por essa razão, decerto, manifesta o legislador tamanha repulsa à infidelidade conjugal". ${ }^{82}$

Assim, a infração do dever de fidelidade constitui adultério, indicando a falência da moral familiar, desagregando toda a vida da família, além de agravar a honra do outro cônjuge, injuriando-o gravemente. ${ }^{83}$

O adultério tem como pressuposto necessário a existência de um casamento vinculando qualquer um dos participantes da relação carnal; e se configura ante a presença de um elemento físico, a cópula; e outro moral, a vontade culpável, "a consciência de violar a fé jurada" ${ }^{84}$ Daí se diz que o adultério é a violação dolosa da fé conjugal, reclamando-se que a sua prática tenha sido com conhecimento de causa.

Conforme anteriormente explicitado, a conjunção carnal seria a materialidade do adultério. Não há adultério por infidelidade espiritual ou platônica. O conceito de conjunção carnal, todavia, não tem sido fixado de maneira uniforme. Uns exigem para a sua configuração a cópula efetiva e normal pelo seminário intra vas, outros estendem seu conceito até os simples atos de libidinagem. Alguns entendem que a materialidade do

\footnotetext{
${ }^{79}$ CAHALI, Yussef Said. Adultério e desquite. 1972. Tese (Livre-docência) - Faculdade de Direito, Universidade de São Paulo, São Paulo. p. 10.

${ }^{80}$ LIMA, Domingos Sávio Brandão. op. cit., p. 470.

${ }^{81}$ Cf. Id. Ibid., p. 449.

${ }^{82}$ RODRIGUES, Silvio. Direito civil: direito de família. 28. ed. São Paulo: Saraiva, 20004. p. 125.

${ }^{83}$ Cf. DINIZ, Maria Helena. Curso de direito civil: direito de família. cit., p. 123.

${ }^{84}$ CAHALI, Yussef Said. Adultério e desquite. cit., p. 69.
} 
delito se definiria como sendo ato que permite ao homem e à mulher conceber. Outros, mais cautelosos, definem a conjunção carnal como sendo ato que consiste na introdução do órgão genital de uma pessoa no corpo de outra, por via normal ou anormal. ${ }^{85}$

Genericamente, portanto, considera-se violada a fidelidade quando ocorre o adultério, ou seja, pela prática de relação sexual de um dos cônjuges com terceiro, o que pode ser um fato isolado ou esporádico. Mas não-só deste modo se descumpre o dever de fidelidade. Enquanto o adultério somente se configura pelo completo congresso carnal de pessoa casada com terceiro, "a ofensa ou violação ao dever de fidelidade, atualmente, segundo a maior parte da doutrina, deve ter interpretação mais abrangente." $\$ 6$

De fato. Se o bem jurídico tutelado é a fé conjugal, isto é, a promessa recíproca de exclusiva posse, seria ilógico excluirem-se do adultério as práticas pervertidas que vilipendiam a fé conjugal empenhada.

Assim, podemos afirmar que a fidelidade é o gênero, do qual o adultério é apenas uma das espécies de infração. ${ }^{87}$ Embora, em princípio, seja caracterizada a violação ao dever de fidelidade pelo cometimento de adultério, ou seja, pela cópula com estranho, ele não se descumpre somente assim.

“Em outros termos, o dever de fidelidade não se limita à abstenção do encontro sexual com estranho. Jurisprudência e doutrina apontam outras hipóteses de violação do dever de fidelidade, além do adultério". ${ }^{88}$

A propósito, Yussef Said Cahali apresenta uma classificação envolvendo a infringência ao dever de fidelidade: o adultério stricto sensu, que se configura pela prática

\footnotetext{
${ }^{85}$ Nesse sentido, CARNEIRO, Alaim de Almeida. Adultério. In: SANTOS, J. M. de Carvalho. Repertório Enciclopédico do Direito Brasileiro. Rio de Janeiro: Borsoi, 1947. v. 2, p. 345.

Carrara entende que o momento consumativo é o da ejaculação dentro da vagina. Bento de Faria defende a "introdução do órgão genital de uma pessoa no corpo da outra, pela via normal ou anormal". Liszt reputa suficiente a união das partes genitais. Outros autores excluem a conjunção carnal da tipificação do adultério, e advogam a integração por qualquer contato libidinoso. Magalhães Noronha adota um conceito mais amplo, abrangendo os equivalentes fisiológicos e sucedâneos - coito anal, interfemoral, fellatio in ore, cunnilingus, annilingus e outros mais. Nelson Hungria entende que basta o ato sexual inequívoco. Cf. LIMA, Domingos Sávio Brandão. op. cit., p. 456-457.

${ }^{86}$ COLTRO, Antonio Carlos Mathias; FIGUEIREDO, Sálvio de; MAFRA, Tereza Cristina Monteiro. Comentários ao Novo Código Civil. Rio de Janeiro: Forense, 2005. v. 17, p. 298

${ }^{87}$ Cf. MADALENO, Rolf. Direito de família: aspectos polêmicos. Porto alegre: Livraria do Advogado, 1998. Ao se falar em infidelidade, surge inegavelmente a figura do adultério. Este não é, por si só, forma exclusiva de quebra do dever de fidelidade, sendo considerado, tão somente, uma de suas espécies. Cf. GARCIA, Carolina Ribeiro. op. cit.

${ }^{88}$ Neste sentido vem se firmando a jurisprudência, considerando desnecessária a consumação do ato sexual para caracterização da infidelidade, bastando que tenha ocorrido qualquer deslize conjugal, envolto em sensualidade, revelador de uma excessiva intimidade ou afeição carnal com estranho para configurar a infidelidade. Cf. COLTRO, Antonio Carlos Mathias; FIGUEIREDO, Sálvio de; MAFRA, Tereza Cristina Monteiro. op. cit., p. 299.
} 
de relação sexual com outra pessoa, que não o cônjuge, mas enfrenta grande dificuldade de comprovação; o quase-adultério, de interpretação mais abrangente, inclui os atos que denunciam o propósito de concluir o adultério, não-ultrapassada a fase preparatória dos atos tendentes à sua prática; e o adultério casto, que se caracteriza pela inseminação artificial realizada sem o conhecimento e consentimento do outro cônjuge, com sêmen de homem estranho. Nestes dois últimos casos, ocorre a argüição genérica de conduta desonrosa ou injúria grave, que pode levar às mesmas conseqüências do adultério stricto sensu, se vier a tornar insuportável a vida em comum. ${ }^{89}$

O quase-adultério corresponderia, portanto, ao adultério moral, infração genérica ao dever de fidelidade, sendo considerado uma injúria-grave à honra do outro consorte.

Na opinião de Carlos Roberto Gonçalves, "os atos meramente preparatórios da relação sexual, o namoro e os encontros em locais comprometedores não constituem adultério, mas podem caracterizar a injúria grave (quase adultério), que também é causa de separação". ${ }^{90}$

Nas palavras de Fernando Brandão Ferreira Pinto: "surge-nos a violação do dever de fidelidade conjugal quando qualquer dos cônjuges estabelece com um terceiro um relacionamento amor-instinto-sexo igual ou idêntico ao que é possível estabelecer com o outro cônjuge, ou não tem com relações sexuais. Cabem aqui, portanto, a conjunção carnal, ou um simples flirt, que não passa de uma mera ligação amoroso-platônica com um estranho e, ainda, a recusa do débito conjugal". ${ }^{91}$

A própria orientação constitucional alargou consideravelmente o conceito de fidelidade. Além de significar a proibição do adultério, engloba vários comportamentos que cindem a fé conjugal, por sua licenciosidade ou leviandade, de modo que o dever de fidelidade tem os contornos delineados de acordo com a dedicação exclusiva e sincera entre os cônjuges. ${ }^{92}$

${ }^{89}$ Cf. CAHALI, Yussef Said. Divórcio e separação. 10. ed. São Paulo: Revista dos Tribunais, 2002. p. 324 e ss.

${ }^{90}$ GOLNÇALVES, Carlos Roberto. Sinopses jurídicas: direito de família. 10. ed. São Paulo: Saraiva, 2005. p. 46.

${ }^{91}$ PINTO, Fernando Brandão Ferreira. Causas do divórcio. Coimbra: Livraria Almedina, 1980. p. 66-67.

92 Afirma Francesco Scardulla: "La facultà coniugale non consiste soltanto nel non commettere adulterio, cioè nel non giacersi con persona diversa dal proprio coniuge, ma nel non trattenere con altri legami amorosi anche di natura puramente spirituale". (SCARDULLA, Francesco. La separazione personale dei coniugi ed il divorzio. 2. ed. Milão: Giuffrè Editore, 1977. p. 46; apud RIZZARDO, Arnaldo. Direito de família. cit., p. 170 . 
O terapeuta Frank Pittman define o adultério como o ato sexual fora do casamento, ao passo que a infidelidade seria uma desonestidade sexual dentro do casamento. Para ele o adultério é contra a lei, ou contra a vontade de Deus, mas a infidelidade é contra o casamento, exatamente porque rompe com os acordos conjugais..$^{93}$

Nesse sentido, preferimos adotar o entendimento de Yussef Said Cahali, que afirma "na figura do quase-adultério inclui-se o comportamento conjugal intencionado no sentido do congresso sexual com estranho, exaurido nos atos preparatórios ou circundantes, como também se inclui o deslize envolto em sensualidade, porém despido de qualquer contato carnal, representado pela infidelidade moral ou espiritual". ${ }^{94}$

Dentro do conceito moral vigente, portanto, o adultério constitui séria injúria ao consorte. ${ }^{95}$ Além disso, "atos diversos do ato sexual podem caracterizar injúria grave, bastante para lastrear pedido de separação". ${ }^{96}$

Sob este prisma, também é importante ressaltar que ainda existem controvérsias na doutrina sobre a configuração do adultério pela união sexual com pessoa do mesmo sexo (união homossexual). Entendemos que neste caso há uma violação do dever de fidelidade, pois tratam-se de práticas não-convencionais que, da mesma forma, atentam contra a fé conjugal empenhada, sendo causa para a separação.

Assim, a infidelidade que não-reúne os caracteres específicos da infração de adultério pode ser reputada, em tese, como injúria grave: qualquer deslealdade conjugal, no sentido de excessiva intimidade ou afeição, representará a violação daquele dever, pois a conduta leviana ou irregular do cônjuge pode ser tal que ofenda a dignidade da família. ${ }^{97}$

\footnotetext{
93 PITTMAN, Frank. Mentiras privadas. Porto Alegre: Artes Médicas, 1994. p. 6.

94 CAHALI, Yussef Said. Divórcio e separação. 10. ed. cit., p. 343.

95 "No conceito de injúria grave seria lícito reconhecer que está obviamente contida a prevaricação pelo congresso carnal de um dos esposos com outra pessoa". BITTENCOURT, Edgard deMoura. Família. Rio de Janeiro: Alba, 1995. p. 73.

96 VENOSA, Silvio de Savio. Direito civil: direito de família. 3. ed. São Paulo: Atlas, 2003. v. 6, p. 157. "A infidelidade embora encontre manifestação material no adultério tem razões capazes de construir explicações para além dos limites estreitos da objetividade". COLARES, Marcos. Onde mora a in(fidelidade)? cit., p. 195.

${ }^{97}$ Cf. CAHALI, Yussef Said. Adultério e desquite. cit., p. 255.
} 
2.5. Deslealdade

É possível conceituar o dever de fidelidade como a lealdade entre os parceiros, especialmente no que tange às relações cujo principal objetivo seja o prazer físico e a satisfação sexual. ${ }^{98}$

Para Regina Beatriz Tavares da Silva, "a fidelidade é o dever de lealdade, sob o aspecto físico e moral, de um dos cônjuges para com o outro, quanto à manutenção de relações que visem à satisfação do instinto sexual dentro da sociedade conjugal'. ${ }^{99}$

Assim, a fidelidade deve ser entendida no sentido físico e moral, ou seja, como manutenção de relações sexuais exclusivamente com o outro cônjuge e dever de lealdade de cada membro do casal em relação ao outro. ${ }^{100}$

A infidelidade física é justa causa para a separação judicial litigiosa. Quanto à fidelidade moral, não está munida de sanção eficiente, podendo todavia a deslealdade de um cônjuge em relação ao outro (namoro com terceira pessoa, por exemplo) constituir, conforme o caso, infração grave, que também autoriza a separação judicial litigiosa. ${ }^{101}$

As novas idéias insistem na lealdade, não mais na fidelidade. "A obrigação de não trair sexualmente o parceiro vai decaindo - embora, é claro, isso dependa muito dos acordos que os casais firmem, e seja dificil manter-se uma relação em que a suposta traição se torne rotina -, enquanto se destaca uma nova obrigação, feita de respeito, igualdade e, sobretudo, lealdade". ${ }^{102}$

Nas palavras de Maria Helena Diniz, "para alguns autores o casamento tinha por elemento o dever de fidelidade, e, atualmente, deve basear-se na lealdade dos cônjuges, isto porque a obrigação de não trair sexualmente vem decaindo, destacando-se

\footnotetext{
${ }_{98}$ Nesse sentido, GARCIA, Carolina Ribeiro. O dever de fidelidade no casamento e na união estável e suas possíveis conseqüencias. Disponível em: $<\mathrm{http}: / / \mathrm{www} 1$.jus.com.br/doutrina/imprimir.asp?id=5222>. Acesso em: 16 maio 2005.

99 SANTOS, Regina Beatriz Tavares da Silva Papa dos. Responsabilidade civil dos cônjuges. cit., p.128.

${ }^{100}$ Nesse sentido, WALD, Arnold. O novo direito de familia. 14. ed. São Paulo: Saraiva, 2002. p. 90.

"A fidelidade conjugal é o dever de lealdade, sob o aspecto físico e moral, que veda a manutenção de relações que visem à satisfação do instinto sexual fora do tálamo, sendo resultante do princípio monogâmico que vigora em nossas constituições familiares (...) Seu descumprimento dá-se por meio da prática de atos com terceira pessoa que demonstram o propósito de satisfação do instinto sexual, cheguem ou não à cópula carnal". SILVA, Regina Beatriz Tavares da. Débito conjugal. cit., p. 533.

${ }^{101}$ Cf. WALD, Arnold. O novo direito de família. 14. ed. São Paulo: Saraiva, 2002. p. 90.

${ }^{102}$ RIBEIRO, Renato Janine. A Família na Travessia do Milênio. In: II CONGRESSO BRASILEIRO DE DIREITO DE FAMÍLIA - IBDFAM. A família na travessia do milênio. Belo Horizonte: Del Rey, 2000. p. $15-24$.
} 
a de manter um relacionamento moldado na afeição e respeito. Ora, infidelidade sexual não seria deslealdade e desrespeito?". ${ }^{103}$

Portanto, não se pode mais compreender a fidelidade recíproca no mero sentido de exclusividade do direito do cônjuge às relações sexuais. ${ }^{104}$ Isto é, mesmo que não tenha concluído o adultério, os atos que denunciam tal propósito podem se caracterizar como grave violação ao dever de fidelidade - cuja noção foi ampliada para traduzir uma idéia de lealdade, de comunhão física e espiritual entre os cônjuges -, ainda que não ultrapassada a fase preparatória dos atos tendentes à sua prática. ${ }^{105}$

Ainda é forte a reação social contra toda e qualquer manifestação sexual dos cônjuges com terceiras pessoas, embora a prática revele a infringência generalizada deste dever. O sentido de fidelidade recíproca envolve a dedicação exclusiva e sincera de um cônjuge em relação ao outro, ou um leal compartilhamento de vida, tanto na dimensão material como na espiritual. Assim, há infringência deste dever, também, quando a conduta pessoal reflete uma gama de situações desrespeitosas e ofensivas à própria honra do cônjuge, ou seja, uma infidelidade na forma de agir inconveniente para pessoas casadas. ${ }^{106}$

Além disso, o conceito de lealdade torna-se importante na medida em que também se aplica às uniões estáveis, sendo mais abrangente que o próprio conceito de infidelidade.

A Constituição Federal, de 1988, inseriu o afeto no âmbito da juridicidade, quando nomeou a união estável de entidade familiar, conferindo-lhe proteção do Estado. ${ }^{107}$ Entretanto, boa parte da doutrina considera que a união estável não foi equiparada ao casamento. ${ }^{108}$ Também há diversos julgamentos salientando a diferença dos institutos.

\footnotetext{
${ }^{103}$ DINIZ, Maria Helena. Curso de direito civil brasileiro: direito de família. 17. ed. São Paulo: Saraiva, 2002. p. 124.

${ }^{104} \mathrm{O}$ casamento comporta a mútua entrega, de modo que haja uma comum vivência de lutas, esforços, interesses, colaboração e idealização de vida. Deve haver, portanto, com justa razão, uma evolução de sentido, para conceber-se a fidelidade não-só na dimensão meramente física, mas em uma noção que abranja a pessoa do outro cônjuge. Assim, mais que um simples ato de natureza física, a fidelidade conjugal envolve o critério de vida, ou uma conduta de comprometimento interior e prático dos cônjuges.

${ }^{105}$ Cf. CAHALI, Yussef Said. Divórcio e separação. cit., p. 388 e COLTRO, Antonio Carlos Mathias; FIGUEIREDO, Sálvio de; MAFRA, Tereza Cristina Monteiro. op. cit., p. 299.

${ }^{106}$ Cf. RIZZARDO, Arnaldo. Direito de família. 2. ed. Rio de Janeiro: Forense, 2004. p. 170.

${ }^{107}$ Cf. DIAS, Maria Berenice. Era uma vez... . cit., p. 17.

${ }^{108} \mathrm{Na}$ opinião de Yussef Said Cahali, "tem-se como certo que o casamento continua mantendo a sua dignidade como único expediente legal hábil para a constituição da família, não se lhe equiparando, para os efeitos da lei - especialmente com vistas aos efeitos que dela resultam -, a simples união estável entre o homem e a mulher”. CAHALI, Yussef Said. op. cit., p. 17.
} 
Antes da promulgação da Constituição, de 1988, havia autores que entendiam não existirem deveres impostos aos conviventes em sede de concubinato, ante a perfeita liberdade que havia entre eles. Entretanto, atualmente, os conviventes são obrigados a observar regras semelhantes àquelas inerentes ao contrato matrimonial. ${ }^{109}$

Dispõe o art. 1.724 do Código Civil brasileiro, no que tange à união estável: "as relações pessoais entre os companheiros obedecerão aos deveres de lealdade, respeito e assistência, e de guarda e educação dos filhos". Assim, no âmbito da união estável poder-se-ia mencionar que a ausência do termo "fidelidade" proporcionaria uma maior liberalização neste sentido. No entanto, este dever está expresso no vocábulo "lealdade". ${ }^{110}$

Portanto, a união estável, instituto jurídico recentemente regulamentado pelo nosso Direito, não gera os mesmos direitos e deveres do casamento, mas traz conseqüências semelhantes: não se fala em dever de fidelidade, mas sim dever de lealdade, que da mesma forma traz efeitos para quem o descumpriu. Dessa forma, podemos concluir que elemento primordial da união estável, assim como do casamento, é a fides, fé, ou fidelidade. Sendo que na união estável esse dever é chamado de lealdade, que melhor exprime o vínculo.

Caso algum dos companheiros venha a descumprir esse dever, pode o outro pleitear a dissolução da união estável, devendo o responsável pela desunião do casal responder por um possível ressarcimento do prejuízo causada ao seu companheiro.

\section{Separação e Divórcio}

\subsection{Da Indissolubilidade do Casamento à Possibilidade do Divórcio}

A história relata curiosas passagens relacionadas ao elemento anímico como necessário à ruptura do vínculo matrimonial.

As causas dissolutórias do casamento romano eram: a morte, a incapacidade superveniente e o divórcio, em que as duas primeiras são involuntárias e a última,

\footnotetext{
“Casamento é casamento. União estável é união estável. Trata-se de relações distintas e com denominação diversa. Sua disciplina jurídica é específica (...) A Constituição Federal considera a família a base da sociedade e lhe outorga especial proteção estatal. A união estável forma uma 'entidade familiar' que merece proteção simples. Fossem iguais e o texto não lhes atribuiria denominação diversa”. PENTEADO, Jacques de Camargo. op. cit., p. 361.

${ }^{109}$ Nos dias de hoje, a situação é diversa. Autores brasileiros são categóricos em afirmar que estes deveres impostos aos concubinos retratam a situação atual em que os mesmos se encontram. Nesse sentido, CRISPINO, Nicolau Eládio Bassalo. Responsabilidade civil dos conviventes. In: II CONGRESSO BRASILEIRO DE DIREITO DE FAMÍLIA - IBDFAM. A família na travessia do milênio. Belo Horizonte: Del Rey, 2000. p. $105-120$.

${ }^{110}$ Cf. GARCIA, Carolina Ribeiro. op. cit.
} 
voluntária. O divórcio não era um breve abandono, nascido do império da ira, mas uma desunião que, perdurando, se revelava como conseqüência do propósito maduro e firme de dissolver o matrimônio. ${ }^{111}$ Assim, o casamento, sendo simples fato, poderia vir a dissolverse pela simples vontade de um ou de ambos os cônjuges, independentemente da atuação de um órgão judiciário oficial.

Embora se pretenda que o divórcio tenha sido largamente tolerado e consentido nos primeiros séculos do Cristianismo, é certo que a Igreja desde logo reagiu contra a dissolubilidade do vínculo, tomando como ponto de partida a parábola de Cristo: "não separe o homem o que Deus uniu". ${ }^{112}$ Portanto, somente no Império Cristão é que se iniciam as tentativas de combate ou restrição ao divórcio. ${ }^{113}$

Assim, antes do Cristianismo não havia a disciplina da indissolubilidade senão excepcionalmente. O divórcio era um instituto pouco conhecido, principalmente com as características que adquiriu na atualidade. Os poucos casos em que se admitia a dissolubilidade do vínculo eram mais relacionados à questão da prole, esterilidade, que a deveres conjugais. ${ }^{114}$

Dessa forma, a dissolução por adultério, talvez a principal causa dos divórcios na atualidade, era praticamente desconhecida, talvez porque nos povos da Antigüidade a bigamia era muitas vezes tolerada e incentivada. Como dito anteriormente, essa concepção só mudou com o advento do Cristianismo, que estabeleceu as relações monogâmicas na família, condenando outras formas.

\subsection{Quebra do Dever de Fidelidade}

Frustradas as expectativas de felicidade e realização comum, o fracasso do relacionamento vem acompanhado de traições (no mais amplo sentido da expressão). Surge, então, uma dúvida: o que determinou o fracasso do projeto de felicidade? Ou seja, uma das mais polêmicas questões a respeito da infidelidade é o que determina a sua existência. Poder-se-ia perguntar: por que a infidelidade e não a separação? "Dizem que a oportunidade faz o ladrão; de forma simplista talvez isso sirva para explicar o que faz de alguns de nós 'fiéis' e de outros 'infiéis' nas relações conjugais. Porém, sem dúvida, a

\footnotetext{
${ }^{111}$ Cf. AZEVEDO, Álvaro Villaça. Estatuto da família de fato. 2. ed. São Paulo: Atlas, 2002. p. 52-53.

${ }^{112}$ Cf. CAHALI, Yussef Said. Divórcio e separação. 11. ed. São Paulo: Revista dos Tribunais, 2005. p. 31.

${ }^{113}$ Nesse sentido, LIMA, Domingos Sávio Brandão. Divórcio romano versus divórcio canônico. Revista de Direito Civil , v. 39 n. 12; apud CAHALI, Yussef Said. Divórcio e separação. cit., p. 31.

114 "Na verdade, a monogamia e a indissolubilidade do casamento só se tornaram prática geral no século X, primeiro entre o povo, depois no seio da nobreza". FIÚZA, César Augusto de Castro. op. cit., p. 34.
} 
explicação mais próxima da realidade só vai brotar do estudo da história de vida de cada personagem das relações analisadas". ${ }^{115}$

Fato é que creditar na falta de conseqüências desastrosas que a infidelidade pode trazer é uma hipocrisia. A infidelidade é dolorida e frustrante para quem se sente enganado. Ela pode estar mais relacionada ao orgulho ferido e às mentiras que o cônjuge conta, que com o orgasmo que obtém com o auxílio de outrem. ${ }^{116}$

$\mathrm{Na}$ realidade, "o vírus da moléstia degenerativa constitui uma ameaça presente, por mais cautelosos que tivessem sido os nubentes na escolha do companheiro, que se supunha ideal para toda a vida". ${ }^{117}$

Nas palavras de Marcos Colares, "Considero curioso ofato de que usualmente a fidelidade á aliada ao compromisso, à moral, à honra; enquanto a infidelidade vitaliza termos como desejo e paixão (...) parece que vivemos a contenda dicotomica da virtude versus o vício". ${ }^{118}$

"Cabe então perguntar: a maioria da sociedade brasileira (...) é partidária e praticante da fidelidade conjugal? (...) No Brasil, o binômio amor-fidelidade é tema regularmente explorado". ${ }^{119}$

Podemos concluir que a fidelidade, enquanto dever de um e direito do outro, vige durante o casamento, mas só a sua quebra serve de fundamento para justificar a busca de seu término. ${ }^{120}$ A violação do dever de fidelidade autoriza o cônjuge traído a alegar causa de rompimento da relação conjugal. ${ }^{121}$ Cabe ao cônjuge ofendido, com exclusividade, a imputação ao outro da infidelidade, sendo-lhe facultado perdoar o infrator.

Assim, a violação do dever de fidelidade foi, é e será o fundamento mais invocado para a ação de divórcio. Vale lembrar que basta uma só transgressão ao dever de fidelidade para que se configure a sua quebra, não se exigindo a continuidade de relações carnais com terceiro ou que o culpado mantenha o relacionamento extraconjugal.

\footnotetext{
${ }^{115}$ COLARES, Marcos. Onde mora a in(fidelidade). In: NAZARETH, Eliana Riberti; MOTTA, Maria Antonieta Pisano (Coords.). Direito de Família e Ciências Humanas: Caderno de Estudos n. 2. São Paulo: Jurídica Brasileira, 1998. p. 196.

${ }^{116}$ Nas palavras de André Comte-Sponville: “o amor me parece menos traído pelo amor (pelo outro amor) do que pela mentira”. (COMTE-SPONVILLE, André. Pequeno tratado das grandes virtudes. São Paulo: Martins Fontes, 1999. Tradução de Eduardo Brandão. Disponível em: <http://br.geocities.com/mcrost04/pequeno tratado_das_grandes_virtudes_03.htm>. Acesso em: 17 maio 2005.

${ }^{117}$ CAHALI, Yussef Said. Divórcio e separação. 10. ed. cit., p. 20.

118 COLARES, Marcos A. P. O que há de novo no direito de família? cit., p. 183.

${ }^{119}$ COLARES, Marcos. Onde mora a in(fidelidade)? cit., p. 187.

${ }^{120} \mathrm{Cf}$. DIAS, Maria Berenice. $O$ dever de fidelidade. cit.

${ }^{121}$ Nas palavras de Yussef Said Cahali, "a violação do dever de fidelidade representa a mais grave das infrações dos deveres conjugais”. (CAHALI, Yussef Said. Divórcio e seperação. 10. ed. cit., p. 324.
} 
A questão da infidelidade é deixada ao arbítrio dos cônjuges por envolver matéria de foro íntimo. ${ }^{122}$ Fato é que esse dever subsiste enquanto durar a sociedade conjugal.

\subsection{O Papel da Culpa}

À luz de nossa mais profunda tradição ética, o prazer não é facilmente absorvido desvinculado do elemento culpa. ${ }^{123}$

No Direito de Família, a culpa expressa-se no momento patológico do casamento, ou seja, na ruptura da sociedade conjugal, quando alguém é responsabilizado por não querer mais viver com seu cônjuge. ${ }^{124}$

O Direito cria deveres recíprocos aos cônjuges e "quem descumpri-los, além de carregar consigo o sentimento de culpa, será punido, para garantir que essas regras não sejam apenas morais, mas também jurídicas". ${ }^{125}$

Assim, a culpa é compreendida como a quebra intencional dos deveres matrimoniais bilateralmente impostos, e sempre atribuiu àquele que descumpre tais obrigações amorosas conseqüências consistentes na perda de determinados direitos e imposições de determinadas sanções. ${ }^{126}$

No regime do Código Civil, de 1916, anteriormente à Lei do Divórcio, o casamento era indissolúvel, configurando-se duas espécies de desquite: consensual e

\footnotetext{
${ }^{122}$ Vislumbram-se casos em que um dos consortes, apesar de ciente do adultério (da quebra do dever de lealdade), perdoa e mantém a relação afetiva, acreditando na recuperação e prosseguimento de ideais de vida comuns. Cf. FARIAS, Cristiano Chaves de. Redesenhando os contornos da dissolução do casamento (casar e permanecer casado: eis a questão). In: IV CONGRESSO BRASILEIRO DE DIREITO DE FAMÍLIA - IBDFAM. Afeto, ética, família e o novo código civil. Belo Horizonte: Del Rey, 2004. p. 118.

${ }^{123}$ Derivada do pecado original, metaforicamente representada pela maçã mordida no paraíso, a culpa já estava presente na tradição ética judaico-cristã, em que a reprodução humana, o relacionamento conjugal e as relações de trabalho, atividades que, de certo modo, resumem a vida do homem em sociedade, estavam associados à idéia de expiação dos pecados. Nesse sentido, TEPEDINO, Gustavo. O papel da culpa na separação e no divórcio. I CONGRESSO BRASILEIRO DE DIREITO DE FAMÍLIA - IBDFAM. Repensando o direito de família. Belo Horizonte: Del Rey, 1999. p. 191.

"Sendo o desejo mais forte que a proibição, instalou-se o pecado original". PEREIRA, Rodrigo da Cunha. $A$ culpa no desenlace conjugal. cit., p. 139.

${ }^{124}$ No casamento, quando se depara com o cotidiano, constata-se uma realidade completamente diferente daquela idealizada. Instala-se, então, o litígio conjugal para procurar um culpado. Cf. PEREIRA, Rodrigo da Cunha. A culpa no desenlace conjugal. cit., p. 137.

"Os restos de amor levados ao Judiciário, para que o Juiz sentencie quem é o culpado, acabam transformandose, muitas vezes, em verdadeira história de degradação da outra parte. Cada cônjuge quer atribuir ao outro a culpa pelo fim do casamento". Id. Ibid., p. 146.

${ }^{125}$ Id. Ibid., p. 141.

${ }^{126}$ Cf. FARIAS, Cristiano Chaves de. op. cit., p. 109.
} 
litigioso, este associado sempre à idéia de culpa. A culpa, portanto, estava intensamente presente no desquite litigioso, que dependia de prova do adultério, tentativa de morte, sevícias ou injúria grave ou abandono do lar conjugal durante dois anos. ${ }^{127}$

Posteriormente, procurou-se abrandar o sistema, prevendo-se, ao lado da chamada "separação-sanção", associada à presença da conduta culposa, a "separaçãoremédio"128 e a "separação-falência", derivadas da constatação fática da falência do casamento, ou de doença incurável que torne impossível o convívio conjugal.

No que tange aos efeitos patrimoniais, o papel da culpa também estava presente nos alimentos. ${ }^{129}$ Assim, insistia-se em associar alimentos à culpa, numa reação punitiva, como uma condenação a morrer de fome o cônjuge culpado.

Outro aspecto relevante no tocante à culpa refere-se à possibilidade de perda do sobrenome pela mulher após a separação, tendo, também, um caráter nitidamente punitivo. ${ }^{130}$

Por fim, inseria-se no rol das conseqüências da culpa na separação, a possibilidade de perda da guarda dos filhos pelo cônjuge culpado. ${ }^{131}$ Tratava-se de dispositivos equivocados e retrógrados, que acabavam por castigar também os filhos. Contudo, vinham sendo temperados pela jurisprudência no sentido de definir a guarda

\footnotetext{
${ }^{127}$ Não havendo outra forma de desquite unilateral, senão a litigiosa, não raras vezes forjavam-se circunstâncias para imputação da culpa ao outro cônjuge, em particular na hipótese de adultério, o que causava enorme constrangimento para os cônjuges e para os filhos. Além disso, sendo o casamento indissolúvel, era inegável o estigma da culpa atribuído a quem pretendesse se separar. Havia enorme preconceito, principalmente com relação à mulher desquitada, sendo tratada como uma pessoa posta à margem das relações familiares. Cf. TEPEDINO, Gustavo. O papel da culpa na separação e no divórcio. I CONGRESSO BRASILEIRO DE DIREITO DE FAMÍLIA - IBDFAM. Repensando o direito de família. Belo Horizonte: Del Rey, 1999. p. 193.

${ }^{128}$ Em um primeiro momento, a separação-remédio ainda tinha alguns resquícios de culpa, projetado na perda patrimonial de quem tomasse a iniciativa da separação.

${ }^{129}$ Dispunha o art. 19 da Lei do Divórcio (Lei n. 6.515/77): "o cônjuge responsável pela separação prestará ao outro, se dela necessitar, a pensão que o juiz fixar". Pela leitura desse dispositivo punitivo, podemos observar que a lei brasileira, em um sério equívoco, não conseguiu desatrelar culpa de necessidade, possibilidade de responsabilidade.

${ }^{130} \mathrm{O}$ art. 17 da Lei n. 6.515/77 determinava que a mulher voltasse a usar seu nome de solteira se fosse vencida na separação judicial. Ou seja, a subtração do nome de família, considerada atributo da identificação pessoal da mulher, era tida como uma sanção na separação culposa, refletindo seu comportamento durante o casamento.

${ }^{131}$ De acordo com o art. 10 da Lei do Divórcio (Lei n. 6.515/77), a guarda dos filhos ficará com o cônjuge que não tiver dado causa à separação. Na disciplina da guarda dos filhos, o art. 326 do Código Civil de 1916 estabelecia os seguintes critérios: se o cônjuge fosse inocente, ficaria com a guarda de todos os filhos; se houvesse culpa recíproca, a mãe ficaria com as filhas, enquanto menores, e com os filhos de até seis anos de idade, e o pai, com os filhos acima de seis anos.
} 
em favor do melhor interesse dos filhos menores, não sendo mais tolerado condicionar a convivência familiar dos filhos de pais separados à vida conjugal fracassada. ${ }^{132}$

Assim, no regime do Código Civil, de 1916, a noção de culpa identificava um comportamento causador de dano injusto, ou seja, a dissolução do vínculo conjugal. ${ }^{133}$ Daí decorria o regime rígido de preservação da estrutura familiar em torno do casamento. ${ }^{134}$ A culpa sempre esteve arraigada na legislação infraconstitucional brasileira, trazendo consigo a idéia de punição e vingança.

Entretanto, recentemente, o papel da culpa na separação tem sido atenuado. Trata-se de uma tendência dominante na política legislativa contemporânea, ${ }^{135}$ embora ela continue presente na cultura do Direito de Família. ${ }^{136}$ Diante disto, passemos a uma reflexão crítica a respeito do regime jurídico brasileiro.

No Brasil, o primeiro sinal dessa evolução, embora tímido, foi a possibilidade de a separação de fato por um ano autorizar o pedido de separação judicial sem necessidade de se discutir culpa. Não haveria mais necessidade de justificar ao Estado o motivo da separação. A separação judicial, assim, passou a se basear em circunstâncias puramente objetivas: verificação de fatos que tornam intolerável a prossecução da vida em comum. Por um lado, portanto, afigurava-se a tendência de se atenuar o papel da culpa na separação judicial, enquanto por outro, sua presença permanecia nos efeitos da ruptura matrimonial, atraindo sanções de várias espécies.

\footnotetext{
${ }^{132}$ Cf. TEPEDINO, Gustavo. O papel da culpa na separação e no divórcio. I CONGRESSO BRASILEIRO DE DIREITO DE FAMÍLIA - IBDFAM. Repensando o direito de família. Belo Horizonte: Del Rey, 1999. p. 197.

“Aquele que não tiver sido um 'bom' cônjuge, pode ser um bom pai, ou uma boa mãe, e da mesma forma o contrário". PEREIRA, Rodrigo da Cunha. A culpa no desenlace conjugal. cit., p. 142.

${ }^{133}$ Nas palavras de Gustavo Tepedino: "o rompimento da sociedade conjugal, portanto, afigurava-se como um esfacelamento da própria família, reprovado socialmente, a despeito das causas subjetivas que o motivaram”. (TEPEDINO, Gustavo. op. cit., p. 202).

134 “Provavelmente a manutenção do princípio da culpa, assim como foi durante muitos anos o da indissolubilidade do vínculo matrimonial, sustenta-se também na boa intenção da tentativa de manutenção das famílias e de que se não houver sanções os deveres conjugais perderiam seu sentido. Na verdade isto é uma falácia histórica. As pessoas continuam casando e separando pelos velhos e bons motivos de sempre. É claro que antigamente havia menos separações e havia, como ainda há, impedimentos morais, jurídicos e religiosos que aparentemente cerceiam tais separações. Mas no fundo o motivo real e determinante da união, ou desunião, será sempre o mesmo, em qualquer tempo ou espaço, ou seja, a determinação do sujeito desejante e o eterno desafio em dar e receber amor". PEREIRA, Rodrigo da Cunha. A culpa no desenlace conjugal. cit., p. 151.

${ }^{135}$ Os ordenamentos jurídicos estrangeiros têm atenuado a culpa e seus efeitos nas separações conjugais

${ }^{136}$ Cf. TEPEDINO, Gustavo. op. cit., p. 192.
} 
Com a promulgação do Código Civil, de 2002, esses resquícios da culpa nas sanções foram atenuados ou retirados por completo ${ }^{137}$. Assim, não há mais que se falar em perda da guarda dos filhos, do direito aos alimentos e do sobrenome. Pode-se afirmar que os paradigmas e princípios estruturadores do Direito de Família, como a culpa, estão se modificando, e seus elementos básicos estão se desatrelando uns dos outros.

Na doutrina, já havia diversas manifestações a respeito da culpa e seu papel nas relações conjugais. ${ }^{138}$ Passemos a algumas delas.

Na opinião de Antonio Cezar Peluso, "parece óbvio que tal disciplina é inspirada por um juízo ético-jurídico de censura de comportamentos, baseada numa visão tosca do nexo de imputabilidade moral". ${ }^{139}$ Ele também afirma que "a valoração da culpa como fundamento de sanções só tem sentido dentro de uma concepção puramente contratualista do matrimônio (...) É como se fora lícito atribuir às violações dos deveres inerentes ao matrimônio o mesmo regime jurídico dos inadimplementos negociais (...) É esta a idéia inaceitável que vigora por detrás do princípio da culpa". ${ }^{140}$

Para Rodrigo da Cunha Pereira, "pensar e repensar a culpa no desenlace conjugal significa refletir sobre sua origem, entender as mudanças e transformações da família, a evolução do pensamento científico, compreender a pessoa humana em sua dimensão mais profunda e, sobretudo, considerá-la como sujeito desejante e no contexto de sua família, pois afinal é nela que se estrutura o sujeito". ${ }^{141} \mathrm{Na}$ sua opinião, "a culpa carrega consigo uma idéia de punição, de vingança (...) a concepção jurídica da culpa tem sua fonte em princípios que nem sabemos localizar exatamente, tão distante e arraigada que está entre nós (...) investigar sobre a culpa é adentrar uma das questões mais inquietantes do ser humano. É pensar na angústia existencial e na eterna luta entre o bem e o mal que há em cada um de nós". ${ }^{142}$ Ele prossegue, ainda, afirmando que: "o caso

\footnotetext{
137 “O Código Civil, de 2002, eliminou os exageros da culpa”. SILVA, Regina Beatriz Tavares da. Débito conjugal. In: IV CONGRESSO BRASILEIRO DE DIREITO DE FAMÍLIA - IBDFAM. Afeto, ética, família e o novo código civil. Belo Horizonte: Del Rey, 2004. p. 540.

${ }^{138}$ A doutrina divide-se em duas grandes correntes antagônicas no que tange à culpa na separação litigiosa. A mais antiga e conforme o ordenamento jurídico recomenda a manutenção da investigação da culpa com sanções ao culpado. A corrente mais atual recomenda uma revisão legislativa para que o princípio da culpa seja substituído pelo princípio da ruptura e o desamor aceito como causa justificadora e autorizadora da dissolução do vínculo, sem outros efeitos.

${ }^{139}$ PELUSO, Antonio Cezar. A culpa na separação e no divórcio: contribuição para uma revisão legislativa. In: NAZARETH, Eliana Riberti; MOTTA, Maria Antonieta Pisano. (Coords.). Direito de família e ciências humanas: caderno de estudos n. 2. São Paulo: Jurídica Brasileira, 1998. p. 42.

${ }^{140}$ Id. Ibid., p. 49-50.

${ }^{141}$ Id. Ibid., p. 133.

${ }^{142}$ PEREIRA, Rodrigo da Cunha. A culpa no desenlace conjugal. NAZARETH, Eliana Riberti; MOTTA, Maria Antonieta Pisano. (Coords.). Direito de família e ciências humanas: caderno de estudos n. 2. São Paulo:
} 
específico da culpa pela dissolução do casamento não é diferente da idéia de vingança ou crueldade. Entretanto, o imperativo ético não deveria ser este (...) Precisamos repensar séria e profundamente a questão da culpa na conjugalidade. Talvez devêssemos começar substituindo-a pela noção de responsabilidade, considerando que aquela paralisa e esta constrói". ${ }^{143}$

Nas palavras de Maria Berenice Dias, "vincular a separação ao rígido pressuposto da identificação de um responsável não se justifica. Cada vez mais vêm a doutrina e a jurisprudência desprezando a perquirição da culpa para chancelar o pedido de separação: basta um dos cônjuges ter por insuportável a vida em comum para dar ensejo ao rompimento do casamento, sendo despicienda a comprovação da culpa de qualquer deles pelo fim do vínculo afetivo". ${ }^{144}$

Por fim, na opinião de Rolf Madaleno, "o único caminho aceitável e que infelizmente não foi visionado pelo novo Código Civil brasileiro respeita às causas objetivas de separação, que trilha pela total abstração da culpa na separação judicial, servindo como suficiente motivação, a própria voluntas divortiandi, da qual emana às claras, que a convivência é impossível". ${ }^{145}$

Para muitos desses autores, a intromissão da culpa nas dissoluções matrimoniais contraria a dignidade humana e a guerra judicial gera a perda da intimidade. Assim, as causas e efeitos da dissolução devem ser independentes da perquirição de culpa, atentando-se à objetividade da crise.

Por outro lado, ainda há quem sustente a permanência da culpa nas relações familiares. Nas palavras de Regina Beatriz Tavares da Silva, "como abolir um conceito que trata do descumprimento de uma norma de conduta? Tal abolição importaria na transformação de um dever em mera recomendação, na transmutação da norma jurídica em regra de cunho puramente moral, cuja violação não geraria qualquer conseqüência a seu infrator". ${ }^{146}$

Fato é que não é mais consentido imputar sanções pelo simples fato da ruptura do vínculo matrimonial, sem que se identifique, especificamente, a prática de

Jurídica Brasileira, 1998. p. 139.

${ }^{143}$ PEREIRA, Rodrigo da Cunha. A culpa no desenlace conjugal. NAZARETH, Eliana Riberti; MOTTA, Maria Antonieta Pisano. (Coords.). Direito de família e ciências humanas: caderno de estudos n. 2. São Paulo: Jurídica Brasileira, 1998. p. 139-140.

${ }^{144}$ Id. Ibid.

${ }^{145}$ MADALENO, Rolf. op. cit.

${ }^{146}$ SILVA, Regina Beatriz Tavares da. A culpa nas relações de família. In: DELGADO, Mario Luiz; ALVES, Jones Figueiredo (Coords.). Questões controvertidas no direito de família e das sucessões. São Paulo: Método, 2005, (Série Grandes Temas de Direito Privado). v. 3, p. 67-103. 
um ato ilícito. ${ }^{147}$ Entretanto, não podemos concordar com a total abolição da culpa em nosso ordenamento, o que ensejaria comportamentos prejudiciais à persecução da família, moralmente condenáveis em nossa sociedade. ${ }^{148}$ Assim, ainda que despida das sanções previstas anteriormente, a culpa ainda possui um importante papel em nossa sociedade e continua sendo causa para a separação judicial. Não raras vezes, se provado o ato ilícito, ${ }^{149}$ com o prejuízo à honra do cônjuge inocente, a culpa pode até mesmo ensejar o pagamento de indenização pelos danos morais sofridos. Além disso, pensamos que muitas vezes a intervenção do Estado se faz necessária para por fim a situações de grave prejuízo à personalidade.

Por isso, de forma atenuada, a noção de culpa deve prevalecer em nosso ordenamento. Ainda que a separação judicial possa ocorrer independentemente da culpa, ela possui grande importância, nos dias de hoje, pois justifica o pedido de indenização por danos morais, quando a conduta do cônjuge culpado agravou sensivelmente a honra daquele inocente.

\subsection{Separação e Divórcio}

A separação e o divórcio apareceram como soluções extremas, mas necessárias para guardar e garantir a dignidade da pessoa contra os riscos que lhe representa a deterioração do casamento.

A possibilidade de os cônjuges dissolverem a relação conjugal é hoje um dado adquirido nas legislações ocidentais, oriundo de um longo, complexo e controverso percurso tendente à consagração legal do direito ao divórcio.

A regulamentação do divórcio no ordenamento brasileiro se deu em meio a intenso confronto ideológico entre divorcistas e antidivorcistas, o que acabou por ocasionar uma regulamentação limitativa do instituto. ${ }^{150}$

\footnotetext{
${ }^{147}$ Cf. TEPEDINO, Gustavo. O papel da culpa na separação e no divórcio. I CONGRESSO BRASILEIRO DE DIREITO DE FAMÍLIA - IBDFAM. Repensando o direito de família. Belo Horizonte: Del Rey, 1999. p. 205.

${ }^{148}$ Achamos essa posição demasiadamente radical, o que não expressa os objetivos defendidos por este trabalho. Entretanto, fazemos menção a ela para demonstrar a tendência atual de parte da doutrina em retirar totalmente a culpa das relações de família.

${ }^{149} \mathrm{Se}$, diante da falta de amor, o cônjuge não busca a separação judicial ou de divórcio e prefere manter o casamento, traindo o seu consorte, aí, sim, existe o ilícito civil. Amor é sentimento e não dever ou direito. Sua falta não é ilícito civil.

${ }^{150} \mathrm{Na}$ época, devido às implicações religiosas, culturais e sociais da ruptura do vínculo, a extinção do casamento, mais do que retratar um fracasso conjugal anterior, representaria, em si próprio, um pecado social. Cf. TEPEDINO, Gustavo. op. cit., p. 194.
} 
A palavra divórcio tem em Direito duas acepções distintas. Assim, uma designa a simples separação de corpos, que não dissolve, rompe o vínculo e, portanto, impede que novas núpcias sejam contraídas. Outra indica o divórcio vincular, absoluto, que dissolve o matrimônio e abre possibilidade para um novo casamento. As duas acepções, porém, participam do mesmo gênero, indicando as soluções que têm sido adotadas como remédio para pôr termo aos conflitos conjugais. ${ }^{151}$

Com a sentença de separação judicial, extingue-se a sociedade conjugal, mas não o casamento. O vínculo conjugal permanece, impedindo que os cônjuges venham a contrair novas núpcias. Não-obstante, cessam os deveres conjugais, de coabitação e fidelidade recíproca, bem como o regime matrimonial de bens. Com o divórcio, extinguese também o vínculo conjugal. Esvai-se por completo o casamento, com todas as suas conseqüências jurídicas. ${ }^{152}$

São causas da separação judicial a conduta desonrosa ou qualquer outro ato que importe em grave violação dos deveres do casamento. ${ }^{153} \mathrm{Na}$ maior parte dos processos judiciais, a causa alegada como ensejadora das separações judiciais está vinculada ao rompimento do dever de fidelidade. ${ }^{154}$ Portanto, qualquer dos cônjuges pode requerer o divórcio se o outro violar culposamente os deveres conjugais, quando a violação, pela sua gravidade ou reiteração, compromete a possibilidade de vida em comum. ${ }^{155}$ Ou seja, não há mais que se questionar a culpa na separação judicial porque relacionamentos como

\footnotetext{
${ }^{151}$ Assim, as concepções variaram da indissolubilidade do vínculo sustentada pelo direito canônico, à dissolução absoluta para atender aqueles casos de um desacordo profundo entre dois seres de vida comum impossível, adotada na atualidade por nosso ordenamento, sendo que algumas legislações adotaram um meio termo, um divórcio de certa forma mitigado, chamado de separação pessoal ou separação de corpos, em virtude do qual o liame matrimonial se encontraria simplesmente atenuado com a liberação de certos deveres conjugais, mas não rompido. Cf. CAHALI, Yussef Said. Divórcio e separação. 11. ed. São Paulo: Revista dos Tribunais, 2005. p. 30 .

${ }^{152}$ Nesse sentido, OLIVEIRA, Euclides Benedito de. Efeitos materiais da separação judicial e do divórcio. In: II CONGRESSO BRASILEIRO DE DIREITO DE FAMÍLIA - IBDFAM. A família na travessia do milênio. Belo Horizonte: Del Rey, 2000. p. 71-92.

153 "Toda infração grave dos deveres conjugais ou conduta desonrosa deve ser apreciada in concreto, em correlação necessária com os padrões convencionais que transcendem de uma realidade social específica". CAHALI, Yussef Said. Divórcio e separação. 10. ed. cit., p. 321.

${ }^{154} \mathrm{Na}$ opinião de Edgard de Moura Bittencourt: "a quebra do dever de fidelidade é de tal forma incompatível com a imposição de vida em comum ao cônjuge inocente que, em verdade, nem precisaria que constasse da lei". BITTENCOURT, Edgard de Moura. op. cit., p. 73.

155 "O divórcio e a separação judicial representam uma sanção indireta cominada em razão do comportamento conjugal que molesta e perturba gravemente a sociedade familiar, tornando insuportável a vida em comum". CAHALI, Yussef Said. Divórcio e separação. 10. ed. cit., p. 47.
} 
estes estão fadados ao fracasso, e em pouco tempo se tornará insuportável a vida em comum $^{156}$.

Constrói-se, assim, o paradigma do desamor, no qual ninguém é obrigado a viver com quem não esteja feliz. Cessado o afeto, está ruída a base segura de sustentação da família, exsurgindo a dissolução do vínculo como modo de garantir a dignidade da pessoa. Assim, a dissolução do vínculo há de ser compreendida, hodiernamente, como um verdadeiro direito da pessoa humana. ${ }^{157}$

Como dito anteriormente, na separação judicial não se questiona mais a necessidade de culpa, bastando que se prove a impossibilidade da vida em comum. Porém, deve o cônjuge inocente comprovar que seu consorte descumpriu um dever, que lhe cabia na constância do casamento para outras finalidades, que não o rompimento do vínculo. $\mathrm{Na}$ maioria dos casos, essa prova será utilizada para instruir o pedido de danos morais, quando pertinente.

\section{Internet}

\subsection{A Era Virtual}

O início do século XXI anuncia a consolidação da era virtual, com o ingresso dos meios eletrônicos de comunicação na sociedade. ${ }^{158}$ Entretanto, é precipitada qualquer projeção sobre o futuro da Internet. Ela ainda é um imenso laboratório em que experiências e estudos estão sendo feitos com o intuito de desvendar seus segredos. ${ }^{159}$

\footnotetext{
156 "Quando uma mulher ou um homem, rompendo o natural recato e segredo existentes em qualquer união, comparece a juízo para incriminar seu consorte de adultério, é porque as tensões e a intolerância atingiram a supersaturação, já ultrapassaram perigosamente os limites, tornando a convivência marital absolutamente impossível". LIMA, Domingos Sávio Brandão. Adultério. In: FRANÇA, Rubens Limongi. (Coord.). Enciclopédia Saraiva do Direito. São Paulo: Saraiva, 1977. v. 4, p. 464.

157 Cf. FARIAS, Cristiano Chaves de. op. cit., p. 105.

158 “A Internet gerou magnífica alteração nos meios de comunicação entre as sociedades, criando forma ágil de interação para os indivíduos, de ponta a ponta do planeta, movendo novas relações surtidoras de diversos efeitos jurídicos". PEREIRA NETO, Miguel. Os documentos eletrônicos utilizados como meio de prova para a constituição de titulo executivo judicial e extrajudicial. In: SHOUERI, Luís Eduardo (Org.). Internet: o direito na era virtual. 2. ed. Rio de Janeiro: Forense, 2001. p. 17.

${ }^{159}$ Nesse sentido, SANTOS, Antonio Jeová. Dano moral na Internet. São Paulo: Método, 2001. p. 21.

"Constituiria mero truísmo afirmar sobre a importância da Internet e sobre o avanço que é navegar nesse mare magnum de informações e disceptações. Tão amplas e variadas são as possibilidades de utilização desse meio de comunicação e informação que, decerto, muito ainda haverá que ser descoberto e inserido no conteúdo da rede mundial de informações". Id. Ibid., p. 15.
} 
A Internet revolucionou os meios de comunicação entre os povos. ${ }^{160}$ Em razão do seu alcance global, facilitou a pesquisa, o trabalho e o desenvolvimento humano. Porém, a transmissão de informações de modo instantâneo entre milhões de pessoas não trouxe apenas benefícios. A Internet também criou oportunidades inéditas para a prática de atos ilícitos.

Neste capítulo buscaremos apresentar, em linhas gerais, os principais aspectos relacionados ao funcionamento da Internet, as formas de comunicação e o papel dos provedores de serviços de Internet. Desde já, adiantamos que ainda não há uma regulamentação expressa a respeito das atividades dos provedores de Internet. As soluções a que chegamos, bem como as conclusões que tiramos, são oriundas da prática, da realidade desses serviços. ${ }^{161}$

A natureza e complexidade da Internet exigem uma abordagem cautelosa, descartando-se soluções simplistas e conclusões apressadas.

\subsection{Definição e Origem da Internet}

A Internet pode ser definida como uma rede internacional de computadores conectados entre si. Tornou-se hoje um meio de comunicação que permite o intercâmbio de informações das mais diversas naturezas, em escala global, com um nível de interação jamais visto anteriormente. ${ }^{162}$

"En realidad, Internet no es algo tangible y concreto, no es um superordenador encargado de comunicar entre sí a los usuarios de ordenadores, sino que

\footnotetext{
160 "En la historia de la humanidad hay avances tecnológicos que son determinantes para su evolución. Algunos de ellos son trascedentales. INTERNET se está erigiendo en uno de los adelantos tecnológicos de mayor impacto de nuestro siglo. Los cambios que el desarrollo de INTERNET propcia van a transformar el modelo de relación interpersonal entre los seres humanos". PARERAS, Luis G. Internet y Derecho. Barcelona: Masson, 1998. p. 2.

${ }^{161}$ Encerram alguns desafios escrever sobre a Internet, quando o tema é voltado para a Ciência Jurídica. A ausência de leis que disciplinem o assunto estimula a desbravar novos caminhos para o aprimoramento de tema que começa a ser inserido na vida das pessoas com a subseqüente repercussão no mundo jurídico.

${ }^{162}$ A Agencia Nacional de Telecomunicações (ANATEL) definiu a Internet como o "nome genérico que designa o conjunto de redes, os meios de transmissão e comutação, roteadores, equipamentos e protocolos necessários à comunicação entre computadores, bem como o software e os dados contidos nestes computadores". Por ocasião da introdução da Internet no Brasil, o Ministério das Comunicações e o Ministério da Ciência e Tecnologia definiram-na como "um conjunto de redes interligadas, de abrangência mundial". Portanto, podese perceber que são inúmeros os conceitos formulados sobre a Internet, mas todos giram em torno dos mesmos elementos. LEONARDI, Marcel. Responsabilidade civil dos provedores de serviços de Internet. São Paulo: Juarez de Oliveira, 2005. p. 1.
} 
es realmente una inmensa red de redes de ordenadores, un consenso mundial acerca de que la información debe ser compartida por todos". ${ }^{163}$

A Internet originou-se do desenvolvimento de um programa militar norteamericano denominado Arpanet, criado, em 1969, com o objetivo de possibilitar a comunicação e a transferência de dados entre seus usuários através de canais redundantes. A partir de 1973, a Arpanet passou a conectar-se com outras redes, inclusive de outros países. Ao final da década de oitenta, a National Science Foundation norte-americana já havia criado sua própria rede e, em 1990, a Arpanet deixou de existir. ${ }^{164}$

No Brasil, seu desenvolvimento iniciou-se através da Rede Nacional de Pesquisa, iniciativa do Ministério da Ciência e Tecnologia, com o objetivo de implementar uma infra-estrutura de serviços de Internet com abrangência nacional, sendo lançada oficialmente, em 1989. No início ela era restrita ao meio acadêmico, áreas de interesse da comunidade de educação e pesquisa do país, mas, com a abertura da Internet comercial, ela passou a estender seus serviços de acesso a todos os setores da sociedade. ${ }^{165}$

No início, temia-se que a Internet pudesse não crescer no Brasil. Evidentemente ninguém imaginava que a rede viria a crescer de forma tão vertiginosa, para os mais diversos fins, originalmente não planejados e, o principal, em um espaço tão curto de tempo.

\subsection{Noções Básicas do Funcionamento da Rede e Formas de Comunicação}

Para uma melhor compreensão do funcionamento da rede, são importantes certas noções básicas sobre as diversas formas de comunicação e as atividades dos provedores de serviços de Internet.

Diversos jargões são comumente utilizados na Internet, por exemplo: backbone, pontos de presença (POP), pontos de acesso (NAPs), roteadores, protocolo de

\footnotetext{
${ }^{163}$ PARERAS, Luis G. Internet y Derecho. Barcelona: Masson, 1998. p. 3.

${ }^{164}$ Cf. LEONARDI, Marcel. Responsabilidade civil dos provedores de serviços de Internet. São Paulo: Juarez de Oliveira, 2005. p. 2-3.

"A Internet não foi concebida como uma rede comercial, e antes do desenvolvimento da World Wide Web, seus usuários seguiam políticas gerais de conduta que expressamente proibiam o uso da rede para fins comerciais". Id.Ibid., p. 3.

${ }^{165} \mathrm{O}$ governo brasileiro demonstrou sua preocupação em deixar a cargo da iniciativa privada a exploração dos serviços no País, adotando uma política de não-intervenção nas relações entre usuários e provedores. Da mesma forma, ele preocupou-se em assegurar a livre iniciativa e a concorrência, garantindo a liberdade de escolha, conforme as necessidades, de usuários e provedores. Cf. LEONARDI, Marcel. op. cit., p. 3-4.
} 
controle de transmissão (TCP), protocolo de Internet (IP), web site, web server, entre outros. ${ }^{166}$

\section{“Cada computador conectado à Internet é parte de uma rede. Quando} um usuário doméstico utiliza a rede através de seu provedor de acesso, seu computador conecta-se à rede daquele provedor. Este, por sua vez, conecta-se a uma rede ainda maior e passa a fazer parte desta, e assim sucessivamente, possibilitando o acesso, dentro de certas condições, a qualquer outro computador conectado à Internet". ${ }^{167}$

É importante ter em mente que a Internet conecta centenas de provedores de diversas cidades em pontos de acesso à rede, com enorme quantidade de dados trafegando entre as redes em tais pontos. Ela representa um grande conjunto de redes de computador, as quais se comunicam por intermédio dos pontos de acesso. Os dados são enviados ao seu destino pela melhor rota possível, o que faz com que a Internet seja eficiente e permita o acesso simultâneo de milhões de usuários, pois o tráfego de dados é automaticamente balanceado entre as rotas que se encontram disponíveis.

Em linhas gerais, todos os computadores conectados à Internet funcionam como servidores, que fornecem serviços e informações na rede, ou como clientes, como são conhecidos no jargão informático, aqueles utilizados para acessar tais serviços e informações. Após a conexão, o computador cliente se comunica com o computador servidor através de protocolos, os quais permitem que os dados sejam compartilhados de diferentes formas, de acordo com o meio e transmissão utilizados. ${ }^{168}$

Evidentemente, todo este processo é invisível ao usuário, e é feito automaticamente inúmeras vezes por dia, por milhares de servidores essenciais ao funcionamento da Internet. ${ }^{169}$

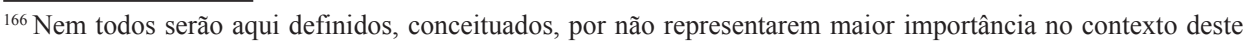
trabalho. Também não trataremos do processo de transmissão de dados propriamente dito, já que envolve grande complexidade de conceitos e, da mesma forma, foge ao tema por nós tratado.

${ }^{167}$ LEONARDI, Marcel. op. cit., p. 5.

168 “A interligação de computadores é possível graças à ocorrência da utilização de determinados protocolos (padronização da linguagem técnica a viabilizar a transmissão de dados); os sinais sonoros transmitidos pelo sistema de telefonia ou rádio são reconhecidos pelo modem, do computador receptor e assim por diante, gerando imensa rede de comunicação e disponibilização de informações e conhecimento". PEREIRA NETO, Miguel. Os documentos eletrônicos utilizados como meio de prova para a constituição de titulo executivo judicial e extrajudicial. In: SHOUERI, Luís Eduardo (Org.). Internet: o direito na era virtual. 2. ed. Rio de Janeiro: Forense, 2001. p. 18.

${ }^{169}$ Os dados trocados pela rede de computadores integrantes da Internet não são materiais, físicos, porquanto não se apresentam de forma transposta ao papel. As informações dispostas na Internet são imateriais e sua materialização (formalização documental) é uma das principais preocupações do ordenamento jurídico vigente, que deve se adequar à nova forma de comunicação.
} 
Assim, a rede Internet constituiu-se numa das melhores e mais eficazes formas de comunicação, caracterizada pela interatividade e por uma fluidez incessante. ${ }^{170}$

Diversas são as formas de transmissão e obtenção de informações via Internet, tais como a world wide web, os mecanismos de busca, o correio eletrônico (email), as listas de discussão e os servidores de notícias, os servidores de FTP (fille transfer protocol), os sistemas peer-to-peer, a execução remota via telnet, o Internet Relay Chat (IRC) e os programas de mensagens instantâneas, entre outros. Pode-se afirmar que a cada dia essas formas de transmissão vão se aperfeiçoando, ou são substituídas por outras mais modernas quando se tornam obsoletas. ${ }^{171}$

É importante entender o funcionamento desses sistemas. Porém, para os objetivos buscados neste trabalho iremos focalizar a atenção nos sistemas de e-mail e chats de bate-papo. ${ }^{172}$

O meio mais conhecido é a world wide web, a "teia de escala mundial" (chamada apenas web no jargão informático), que permite aos usuários buscar e obter informações armazenadas nos servidores, e em alguns casos interagir com os mesmos. A web, portanto, consiste em um vasto número de documentos e dados armazenados em diferentes computadores espalhados pelo mundo, assemelhando-se a uma vasta biblioteca incluindo todo tipo de informações. Assim são as páginas, cada qual com seu endereço eletrônico, que possibilitam a consulta de dados armazenados. Qualquer pessoa pode disponibilizar informações na web, o que é relativamente simples. Para os provedores de

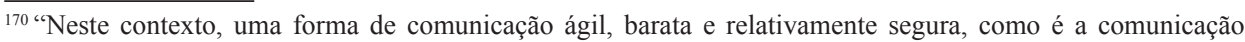
virtual, torna-se um convite a uma nova forma de socialização. Basta um computador e uma linha telefônica para estabelecer a comunicação, não importa a nacionalidade, a idade, o sexo, a raça, a condição social do interlocutor. Para os que estão na rede abre-se um mundo relacional completamente inusitado". GUIMARÃES, Marilene Silveira. Adultério virtual, infidelidade virtual. In: II CONGRESSO BRASILEIRO DE DIREITO DE FAMÍLIA - IBDFAM. A família na travessia do milênio. Belo Horizonte: Del Rey, 2000. p. 439-454.

${ }^{171}$ Nas palavras de Marcel Leonardi: “qualquer pessoa com acesso à Internet pode utilizar uma grande variedade de meios de transmissão e obtenção de informações. Tais meios estão em constante evolução, o que dificulta sua categorização de modo preciso. Importa destacar que todos estes meios podem ser utilizados para transmitir dados, sendo que alguns são mais adequados para a transferência de textos, enquanto outros são recomendados para transmitir sons e imagens (...)". LEONARDI, Marcel. Responsabilidade civil dos provedores de serviços de Internet. São Paulo: Juarez de Oliveira, 2005. p. 10.

${ }^{172} \mathrm{~A}$ democratização no acesso à Internet foi um importante fator para retomada da utilização de formas de comunicação por escrito, sobretudo, o correio eletrônico (eletronic mail - e-mail) e das salas de conversação (chat rooms) que, hoje, operam numa velocidade em tempo real. Nesse sentido, FRAGA, Antonio Celso Galdino. Crimes de informática: a ameaça virtual na era da informação digital. In: SHOUERI, Luís Eduardo (Org.). Internet: o direito na era virtual. 2. ed. Rio de Janeiro: Forense, 2001. p. 365.
} 
serviços, a web constitui uma forma de interagir com os usuários. O $w w w$ torna irrelevante para o usuário a localização física dos documentos recuperados. ${ }^{173}$

O correio eletrônico, ou e-mail (abreviação de eletronic mail), ${ }^{174}$ permite a qualquer pessoa enviar uma mensagem eletrônica - similar a uma carta, nota, ou recado - a outra, ou a um grupo de pessoas, desde que conheça o endereço eletrônico do destinatário. ${ }^{175}$ Este acessa sua caixa postal eletrônica e tem acesso às mensagens que lhe foram enviadas (ficam até então armazenadas em um servidor).

O conteúdo de uma mensagem de correio eletrônico não se limita apenas a textos, podendo ser transmitidos sons, imagens e outras espécies de dados. Não há qualquer limitação quanto ao tipo de informação que pode ser transferida.

Quando diversos usuários pretendem se comunicar na rede de modo simultâneo e em tempo real, podem utilizar os sistemas de conversação simultânea, conhecidos como chat ou bate-papo. ${ }^{176}$ Sendo a comunicação realizada em tempo real, ela evidentemente só se faz possível entre usuários conectados ao servidor em um mesmo momento. O usuário pode optar por enviar mensagens para todas as pessoas do canal ou por restringir a comunicação a grupos ou apenas a um usuário. Neste tipo de serviço, cada

\footnotetext{
${ }^{173}$ Devido ao enorme volume de informações contidos na web, foram criados mecanismos de busca, que facilitam a localização dos arquivos desejados. Seu funcionamento se dá com a utilização de palavras-chaves fornecidas pelo usuário. Ao encontrá-las, tais mecanismos de busca elaboram uma lista de links e a fornecem ao usuário para que este acesse as informações desejadas. O mecanismo de busca mais conhecido atualmente é o Google.

"A informação enviada pela Internet sujeita-se a diversas condições tecnoeletrônicas necessárias à tradução da linguagem do computador àquela utilizada pelo homem comum, sendo a rede mundial de computadores (a WWW - world wide web - a área multimídia da Internet) responsável pela remessa das mensagens (visuais, auditivas, olfativas, sensitivas) de forma instantânea”. PEREIRA NETO, Miguel. op. cit., p. 18.

${ }^{174} \mathrm{Na}$ definição da Rede Nacional de Pesquisa, correio eletrônico "é o serviço básico de comunicação em rede. Também conhecido como e-mail, ou simplesmente mail, o correio eletrônico permite que usuários troquem mensagens via computador, usando um endereço eletrônico como referência para localização do destinatário da mensagem. Assim, este serviço permite a comunicação entre pessoas com interesses comuns, consulta a especialistas, apoio a usuários de produtos comerciais e muito mais". LEONARDI, Marcel. op. cit., p.13.

${ }^{175} \mathrm{O}$ correio eletrônico ou e-mail é um meio excepcional de comunicação, sendo dos mais utilizados na Internet. Ele permite uma comunicação segura na troca de correspondências, e em grande velocidade. Através do email substituem-se os meios tradicionais de cartas, fax, telégrafos, pombos correios e mensageiros.

"Uno de los primeros usos que se lê dio a Internet fue el envío de correo electrónico, también conocido como e-mail (electronic mail). Esta herramienta permite la comunicación electrónica entre los usuarios de la red. Existen varios programas disñados a tal efecto. En cualquier caso, todos los programas gestores de correo electrónico funcionan de modo similar: permiten enviar o recibir mensajes a cualquier parte del mundo en unos segundos". "el envío de correo electrónico es tal vez una de las herramientas más utilizadas de Internet. Permite una comunicación rápida, cómoda y barata entre los usuarios de la red". PARERAS, Luis G. Internet y Derecho. Barcelona: Masson, 1998. p. 10 e 24.

${ }^{176}$ A Rede Nacional de Pesquisa definiu esse sistema como "uma ferramenta que permite estabelecer uma conversação escrita simultânea entre dois ou mais usuários da rede, independentemente de sua localização geográfica (...)".LEONARDI, Marcel. op. cit., p. 17.
} 
participante se identifica mediante um pseudônimo ou nickname, podendo utilizar, além do intercâmbio escrito clássico, a transmissão de voz e teleconferência ou videoconferência (através da webcam). Existem diversos serviços de bate-papo disponíveis na própria web, com objetivos idênticos e funcionamento similar. Assim são as salas de bate-papo, em que os usuários são separados de acordo com os tópicos sugeridos para conversação.

Baseados na popularidade do sistema de bate-papo, foram criados os serviços de mensagens instantâneas, como o Messenger-MSN. Através deles, os usuários que estão conectados ao mesmo serviço se comunicam de forma instantânea, em tempo real. Normalmente, os usuários selecionam as pessoas com quem pretendem se comunicar, criando uma lista de contatos, de forma a saber o momento em que estão conectadas ao sistema. É possível a um determinado usuário comunicar-se de modo individual com um grande número de pessoas simultaneamente.

Estes são, atualmente, os principais meios de comunicação, transmissão e obtenção de dados via Internet. É inevitável que tantos outros sejam inventados no futuro próximo, tornando obsoletos alguns dos que hoje são largamente utilizados. ${ }^{177}$

Por fim, é interessante fazer-se uma breve menção sobre os provedores de serviços de Internet. É comum a confusão entre provedores de backbone, provedores de acesso, provedores de correio eletrônico, provedores de hospedagem, provedores de conteúdo e provedores de informação, atividades completamente distintas que podem ser prestadas por uma mesma empresa a um mesmo usuário ou por diversas empresas, separadamente.

Provedores de serviços de Internet, pessoa natural ou jurídica que fornece serviços relacionados ao funcionamento da Internet, ou por meio dela, é o gênero do qual as demais categorias são espécies. A confusão se dá principalmente porque boa parte dos principais provedores de serviços de Internet realiza todas essas atividades conjuntamente.

A função desses provedores evoluiu em razão do tempo e do crescimento da utilização da rede, sendo comum que eles ofereçam outros tipos de serviços a seus consumidores. Apesar disso, a diferença conceitual subsiste e é fundamental para se

\footnotetext{
177 "Es indudable que estos servicios que hoy en día ofrece Internet serán sustituidos en el futuro por otros más efectivos o potentes. La naturaleza cambiante de Internet así lo exige". PARERAS, Luis G. Internet y Derecho. Barcelona: Masson, 1998. p. 4.

Daqui alguns anos haverá novidades e facilidades que nossas mentes nem imaginam ser possíveis, como há dez anos não se imaginavam as possibilidades dessa verdadeira revolução na comunicação vivenciada nestes dias.
} 
compreender a responsabilidade de tais empresas, variável conforme a atividade específica exercida.

\subsection{Regulamentação da Internet}

A subordinação do homem em relação ao computador ou, melhor dizendo, à rede mundial de computadores, tornou-se um motivo de especial preocupação para a comunidade internacional. Questiona-se a necessidade de se estabelecer uma regulamentação, em âmbito internacional, para nortear as atividades realizadas pela Internet.

Sendo um conjunto global de redes de computador interconectadas, não há nenhum governo, organismo internacional ou entidade que exerça controle ou domínio absoluto sobre a Internet. Cada país é livre para estabelecer as regras de utilização, portanto a regulamentação da rede é feita internamente, sendo atingidos apenas os usuários sujeitos à soberania daquele Estado.

É importante frisar que o chamado "espaço virtual” não existe como realidade física. Não é um Estado soberano, mas apenas uma representação audiovisual criada e mantida por sistemas informáticos e programas de computador, presentes em quase todos os países do mundo. Dessa forma, mostra-se inviável estabelecer regras sobre o que pode ou-não ser divulgado na Internet.

Além disso, o mundo moderno abriga uma variedade enorme de cultura e valores radicalmente diferentes. Uma conduta ilícita à luz de determinado ordenamento jurídico pode nada representar para outro. Nas palavras de Marcel Leonardi: "como nunca existiu, e certamente jamais existirá, um padrão global único de moralidade e decência, quaisquer iniciativas regulatórias ou medidas técnicas adotadas nesse sentido estão inevitavelmente fadadas ao fracasso" ${ }^{178}$.

Do ponto de vista legislativo, verifica-se que as normas já existentes em nosso sistema jurídico são suficientes para regular a atividade dos provedores de serviços de Internet. Não haveria, em princípio, necessidade de criar novas leis a respeito. Entretanto, ainda que o sistema jurídico brasileiro contemple normas gerais que podem ser perfeitamente aplicadas à Internet, os perigos do mau uso da analogia e da excessiva elasticidade na interpretação de dispositivos fazem com que seja recomendável a adoção de leis claras e didáticas a respeito, com o objetivo de afastar, na medida do possível, dúvidas

${ }^{178}$ LEONARDI, Marcel. Responsabilidade civil dos provedores de serviços de Internet. São Paulo: Juarez de Oliveira, 2005. p. 221. 
sobre a natureza, os deveres e a responsabilidade de cada um dos provedores de serviços de Internet. Essa legislação a respeito da Internet deveria ser criada em consonância com os princípios já reconhecidos pela comunidade internacional. ${ }^{179}$

Assim, a tutela dos direitos lesados no âmbito da Internet esbarra em uma série de dificuldades legislativas e práticas. Diante da falta de normas legais específicas sobre a utilização dos serviços disponíveis na Internet e sobre a responsabilidade a eles inerente, os juristas buscam aplicar por analogia normas gerais já existentes sem atentarem às características peculiares da rede, e muitas vezes acreditam encontrarem-se desamparados em razão da ausência de uma legislação específica para a Internet. ${ }^{180}$

Concluímos que o desenvolvimento da Internet mudará todos os parâmetros de relações sociais existentes hoje. O mundo não terá distâncias nem barreiras. Também o direito, como é lógico sofrerá uma mudança radical. ${ }^{181}$

\section{Infidelidade Virtual}

Após todo o exposto, o cerne do tema impõe-se: existe infidelidade virtual, ou seja, a relação virtual, com pessoa diferente do cônjuge, constitui violação do dever de fidelidade? ${ }^{182}$ E sendo violação desse dever, é suficientemente grave para justificar o pedido de divórcio? Para as respostas exige-se uma correta apreensão do que devemos entender por infidelidade virtual.

Assim, o Direito de Família depara-se com uma questão que vem suscitando muitos debates, qual seja, a ciberinfidelidade (que é a infidelidade praticada por meio de comunicação eletrônica). O surgimento de relacionamentos virtuais acabou por inserir profundas modificações no próprio conceito de infidelidade, gerando graves crises nos matrimônios. $^{183}$

${ }^{179}$ Cf. LEONARDI, Marcel. Responsabilidade civil dos provedores de serviços de Internet. São Paulo: Juarez de Oliveira, 2005. p. 225.

180 "Se normalmente a lei se apresenta como um instrumento de inovação social, por vezes se constata que a realidade caminha em velocidade mais acelerada que o processo legislativo. Nessas horas, o papel dos operadores do Direito se torna ainda mais relevante, já que se vêem forçados a encontrar no manto jurídico existente, soluções para conflitos não imaginados pelo legislador". SHOUERI, Luís Eduardo (Org.). Internet: o direito na era virtual. 2. ed. Rio de Janeiro: Forense, 2001. apresentação.

${ }^{181}$ PARERAS, Luis G. Internet y Derecho. Barcelona: Masson, 1998. p. 6.

${ }^{182}$ As atividades sexuais, on-line, revelam uma ampla liberdade e fantasia, e, por isso, os envolvidos também têm dificuldades de definir essas fronteiras com parâmetros do mundo real. O que é permitido e o que não é? Essa pergunta faz parte do cotidiano das relações afetivas, quer de quem mantém uma relação dessa natureza, quer os cônjuges envolvidos/enganados, fazendo com que as percepções pessoais aflorem.

${ }^{183} \mathrm{O}$ casal depende muito do desejo sexual para nascer, mas este desejo é bastante difícil de manter. Talvez seja essa a explicação para muitos saírem em busca de aventuras, mais ainda nos tempos de hoje com as facilidades 


\subsection{A Busca pelo "Sexo" na Rede}

Longe vão os tempos em que se entendia a rede como um mundo restrito e marginal, onde se desenrolavam as mais sórdidas e inconfessáveis experiências. A prática ensina-nos que a Internet faz parte do quotidiano de milhões de pessoas, de todos os níveis sociais, de ambos os sexos, de todas as idades, abrangendo diferentes formações, sendo utilizada para as mais diversas finalidades. ${ }^{184}$

Entre as grandes transformações trazidas pelo advento da Internet, talvez as mais surpreendentes sejam as ocorridas no campo do comportamento sexual.

Desde os primórdios da Internet, todas as estatísticas confirmam que a procura de sexo na rede é uma das suas características mais emblemáticas, tendo a palavra "sexo" ocupado o elenco daquelas mais requisitadas nos programas de busca. ${ }^{185}$

Sob este prisma, impõe-se a pergunta: que tipo de sexualidade as pessoas procuram na Internet? A resposta estabelece uma subdivisão: de um lado estão aqueles que procuram um relacionamento virtual em sentido estrito; de outro, aqueles que utilizam a Internet como meio para atingir um relacionamento carnal ou real.

Sobre os consumidores desses produtos, não há estatísticas devido ao pseudoanonimato da Internet. Entretanto, pesquisas apontam que os homens são a maior parte dos usuários, sendo que também atinge o público feminino.

No que respeita à consulta de conteúdos pornográficos, não encontramos particularidades relevantes para este estudo, pois em nada diferem em relação aos filmes pornográficos e revistas dessa especialidade.

Entretanto, muito relevante é a colocação destes conteúdos na rede, ou seja, quando um dos cônjuges dispõe, sem a anuência do outro, fotos, vídeos ou textos de caráter pornográfico na Internet, suscetíveis de o identificarem. Cogita-se, assim, a caracterização da infidelidade quando o indivíduo casado coloca um anúncio em determinada página com o intuito de conhecer pretendentes. Estaria caracterizada a infidelidade apenas pela intenção, pelo animus?

trazidas pela Internet.

${ }^{184}$ Cf. SILVA, Hugo Lança. op. cit., p. 16.

${ }^{185}$ Um levantamento da Yankelovich Partners Inc. mostra que 60\% das páginas visitadas na Internet têm algum conteúdo sexual. A palavra sex é a mais escrita nos sites de busca em todo mundo. Fonte: Revista Veja, Traição Virtual: a nova modalidade de infidelidade é pela internet: e tumultua a vida dos casais"; Edição 1940, ano 39, n. 3 - 25 de janeiro de 2006, Editora Abril.

"A Internet é quotidianamente utilizada para procura de conteúdos pornográficos, através das mais diversas plataformas: sites, blogues, fóruns, fotos, vídeos, webcam etc”. SILVA, Hugo Lança. op. cit., p. 16.

O tema principal das conversas on-line também é o sexo. 
Existe também o sexo virtual, que dispensa comentários. Em casos como esse, a maioria das pessoas tende a concordar que se trata de uma traição. Neste estudo, não iremos cingir a nossa análise no sexo virtual, encarado numa perspectiva de simples satisfação orgásmica, mas sim na questão do relacionamento virtual propriamente dito. O sexo virtual é demasiado complexo para ser explicado por uma definição simplista. ${ }^{186}$ Portanto, não nos limitaremos a falar de sexo na sua dimensão mais imediata, iremos adotar a noção de relacionamento virtual, conceito mais abrangente e capaz de abarcar uma ampla variedade de modalidades. ${ }^{187}$

Assim, o grande número de usuários da Internet que visita e participa, especialmente de chats e salas de bate-papo destinadas a envolvimentos amorosos e estabelecedores de laços afetivo-eróticos virtuais, tem gerado relevante discussão envolvendo o "clickar do mouse"188: muitas vezes, por trás de um pseudônimo chamativo, está um homem ou uma mulher casada, que se beneficia da rede em busca de uma aventura digital, o que tem suscitado um curioso debate no mundo jurídico sobre a possibilidade de configuração da infidelidade na Internet.

\subsection{Contexto Sócio-Cultural}

Antes de analisar a infidelidade virtual sob o enfoque jurídico, cabe proceder a uma análise do contexto sócio-cultural em que tais relacionamentos ocorrem.

Diante da revolução dos valores, homens e mulheres estão tendo que reinventar novos espaços para suas relações afetivas. Vem surgindo uma nova forma de atração, na qual a aproximação física é substituída pela descoberta de afinidades. Há um envolvimento com a subjetividade do outro, ocorrendo uma espécie de namoro virtual. ${ }^{189}$

"Muitas são as causas que motivam os relacionamentos virtuais. Uns navegam na Internet para atender a uma necessidade natural de conhecer pessoas, para brincar, para fazer descobertas, repetindo o que acontecia antigamente nos

\footnotetext{
${ }^{186}$ Alguns autores o definem como "modalidade através da qual duas pessoas se excitam mutuamente pela Internet através de diálogo picante e simulador de um ato sexual até atingirem o orgasmo, mediante masturbação disjuntiva e simultânea, diante do monitor de um microcomputador". SANTOS, C. B. dos. Adultério virtual. Disponível em: <http://www.ambito-juridico.com.br/aj/dfam0015.htm>. Acesso em: 10 ago. 2006.

${ }^{187}$ É importante deixar claro que nem toda a conversa com conteúdo erótico ou pornográfico qualifica-se como sexo virtual.

${ }^{188}$ DAOUN, Alexandre Jean. $O$ adultério virtual. Disponível em: <http://jus2.uol.com.br/doutrina/texto. asp?id=2564>. Acesso em: 29 maio 2006.

${ }^{189}$ As relações virtuais, portanto, constituem uma nova forma de relacionamento, que parte da descoberta de afinidades, ao contrário do enamoramento tradicional que parte do olhar e do contato físico.
} 
relacionamentos por carta, que se iniciavam por uma amizade sem compromisso. Outros usam os relacionamentos virtuais para vencer a solidão, para vencer o tédio do cotidiano, para preencher carências afetivas. Enquanto uns buscam os relacionamentos virtuais para fugir da relação pouco gratificante que vivem na realidade, outros também usam a sedução exercida no espaço virtual para melhorar a relação com seus parceiros reais". ${ }^{190}$ Estes relacionamentos podem manter-se no plano imaginário ou derivar para uma aproximação física.

Muitas vezes a rotina deteriora os relacionamentos, sejam eles formados pelo casamento ou pela união estável. ${ }^{191} \mathrm{O}$ relacionamento com um terceiro torna-se uma decorrência desse estado de carência afetiva. $\mathrm{Na}$ Internet, a figura idealizada do outro não enfrenta o desgaste da convivência. O que se idealiza sempre é melhor do que se tem. $\mathrm{Na}$ comunicação virtual acontece a construção de uma espécie de "realidade de segunda ordem". Portanto, o espaço virtual se presta como nenhum outro à fuga da realidade frustrante. ${ }^{192}$

Nas palavras de Marilene Silveira Guimarães, "até bem pouco tempo, a fuga inconsciente para o mundo imaginário ficava apenas no terreno da fantasia, no mundo do sonho, único espaço onde se pode ser verdadeiramente livre, onde se pode ser infiel sem que ninguém descubra, onde a infidelidade fantasiosa jamais é confessada a alguém. Agora existe a Internet e o espaço virtual permite 'estar junto' com outra pessoa, permite revelar sonhos e desejos, realizar fantasias, sem riscos aparentes". ${ }^{193}$

Justamente por serem relacionamentos virtuais as pessoas acreditam que são inofensivos, não surge o sentimento de culpa das infidelidades reais, e este é o maior

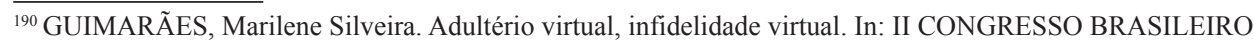
DE DIREITO DE FAMÍLIA - IBDFAM. A família na travessia do milênio. Belo Horizonte: Del Rey, 2000. p. 442.

191 "Para cônjuges envolvidos na rotina de uma relação aborrecida e sem surpresas, a Rede se abre como uma via real para a excitação do adultério (...) Mesmo que não seja consumado o ato de adultério, com o encontro às escuras, quando um dos cônjuges deixa o companheiro para dedicar-se à Internet, a sensação de abandono pode ser trágica". SANTOS, Antonio Jeová. op. cit., p. 203.

Se o casal já não vive bem, já não se comunica, já não é cúmplice, a Internet apenas acelera o processo e proporciona mais oportunidades de se conhecer novas pessoas.

${ }^{192}$ De acordo com o psicólogo francês Loic Roche, autor do livro "Na Cama com a Web", tanto homens quanto mulheres se rendem aos apelos de sites pornográficos e às salas de bate-papo. A iniciativa representa uma fuga da monotonia da vida conjugal. $\mathrm{O}$ mesmo garante que a Internet é uma ameaça à fidelidade conjugal. Disponível em: <http://tecnologia.terra.com.br/interna/0,,oI521254-EI4802,00.html>. Acesso em: 11 ago. 2006.

${ }^{193}$ GUIMARÃES, Marilene Silveira. op. cit., p. 443.
} 
problema. ${ }^{194}$ Entretanto, muitos escondem do cônjuge, pois sabem que no fundo há uma tensão sexual ocorrendo. ${ }^{195}$

Além disso, a possibilidade do anonimato e a privacidade são grandes atrativos da Internet que induzem a esse tipo de relacionamento. É uma forma de superar a timidez, diante da tela do computador você pode ser quem quiser. Muitos se utilizam disso para realizar fantasias eróticas, jamais reveladas. ${ }^{196}$

Outro fator que também impulsiona o crescimento desses relacionamentos é a facilidade com que ocorrem. Neste exato momento, milhares de pessoas estão conectadas à Internet, basta procurar nos lugares certos para iniciar um relacionamento virtual. Pela curiosidade, a cada dia novas pessoas são levadas a experimentar essa novidade.

Assim, a Internet tornou-se uma plataforma de encontros. Os serviços de chats são, para a esmagadora maioria dos usuários, o ponto de entrada para a infidelidade virtual. ${ }^{197}$ Porém, não se deve ter a errônea impressão de que são os únicos instrumentos oferecidos pela Internet para o estabelecimento de relações inter-pessoais; à parte destes, realçamos o correio eletrônico, o Messenger, os fóruns e sites específicos para encontros, que nos últimos anos tem se desenvolvido muito.

Como já citados, são vários os meios na rede que possibilitam a realização do fim sexual, sendo que em alguns casos a troca sexual pode ser incrementada por meio de câmaras digitais, que possibilitam inclusive a identificação do parceiro.

Um site brasileiro realizou a seguinte enquete com seus usuários: a Internet facilita a infidelidade? 53,12\% respondeu que sim, 3,54\% respondeu que não e 43,34\% respondeu que sim, se a pessoa já está motivada a trair. ${ }^{198}$

Portanto, as relações virtuais revelam novos comportamentos, mas a identificação de todas as variáveis que envolvem os conflitos amorosos não é fácil.

\footnotetext{
${ }^{194}$ Diversos estudos demonstram que as pessoas casadas que tiveram um relacionamento virtual não o qualificam como infidelidade.

${ }^{195}$ Para muita gente, a rede é uma forma de trair sem culpa, pois os sentimentos não passam da tela do computador. O problema surge quando se deseja estar fisicamente com quem conheceu na Internet.

${ }^{196} \mathrm{O}$ internauta pode fraudar dados pessoais como estado civil, raça, profissão, idade, tipo físico. Quanto à personalidade, pode demonstrar no espaço virtual características diferentes do seu comportamento social real. No entanto, essa simulação nada mais é do que aquilo que ele desejaria ser na vida real, mas não consegue. Cf. GUIMARÃES, Marilene Silveira. op. cit., p. 443.

${ }^{197}$ Entretanto, é injusto qualificar os freqüentadores de chats como uma horda de pervertidos, motivados pela busca de sexo fácil e prazeres inominados; nas salas de conversação virtual trocam-se opiniões, reflexões, pedem-se conselhos, revelam-se confissões; o recurso a estes pode significar apenas um passatempo, um diferente meio de convívio, sem qualquer conotação sexual. Cf. SILVA, Hugo Lança. op. cit., p. 17.

${ }^{198}$ Disponível em: <http://tecnologia.terra.com.br/interna/0,oI521254-EI4802,00.html>. Acesso em: 28 ago. 2006.
} 


\subsection{A Nova Maneira de Ser Infiel}

A Internet criou uma nova maneira de ser infiel. Mesmo que nunca se transfira para a vida real, a infidelidade virtual traz as mesmas conseqüências e tem sido uma grande polêmica do novo século. ${ }^{199}$

Os serviços de bate-papo pelo computador, como e-mail, Messenger e Orkut, criaram novos paradigmas de traição. Começa com a troca de mensagens eletrônicas, o envolvimento vai crescendo e estabelece-se um vínculo íntimo. Tem todos os ingredientes de um caso extraconjugal, mas, na maioria das vezes, o encontro físico pode nem ocorrer.

A infidelidade virtual tem um padrão típico, a saber: inicia-se com um contato breve em salas de bate-papo virtual, chamadas chats, passa, com o tempo, a ser contatos constantes e periódicos, onde ambos os interlocutores acabam cedendo maiores intimidades um para o outro, transformando-se em relacionamento sério e duradouro, comprometendo o casamento ou a união estável. ${ }^{200}$

Assim, num primeiro momento, trata-se de conversas on-line de conteúdo erótico e pornográfico. Os participantes fantasiam em conjunto, compartilham desejos e experiências relacionados com temáticas sexuais, protegidos por um pseudoanonimato que a rede oferece. É comum, num segundo momento, quando as partes encontram um conjunto de afinidades que as aproximam ou atraem, a partilha de fotos ou a utilização de software de voz e webcam, enquanto perduram os diálogos. Tudo isso acaba por humanizar o relacionamento e o outro deixa de ser uma entidade puramente virtual. ${ }^{201}$ Por fim, as condutas descritas podem suceder-se à prática, recíproca ou-não, de masturbação. ${ }^{202}$ Esta interação poderá apresentar diversas formas, que vão desde a mera escrita, até a utilização

\footnotetext{
${ }^{199}$ Segundo Loic Roche, autor do livro "Na Cama com a Web”, uma em cada vinte relações começa na rede e $15 \%$ dos divórcios são provocados por relações iniciadas num chat. Disponível em: <http://www.emprendedoras. com/modules.php?name=News\&file=print\&sid=834>. Acesso em: 10 ago. 2006.

${ }^{200}$ CARLOMAGNO, Fernando. Aspectos penais e civis da infidelidade virtual. Disponível em: <http://www. direitonet.com.br/artigos/x/17/88/1788/>. Acesso em: 29 maio 2006.

${ }^{201}$ Há de se identificar se o bate-papo se restringiu ao anonimato da Internet ou se houve desdobramentos mais identificáveis e reais.

${ }^{202}$ Alguns autores entendem que se a masturbação for em um momento posterior, não haveria relevante conteúdo jurídico decorrente do fato, tendo as conversas o valor de qualquer outro estímulo erótico. Cf. SILVA, Hugo Lança. op. cit., p. 20.

Não compartilhamos desse entendimento. Seja a masturbação conjunta e partilhada, em um momento posterior, ou, ainda, inexistente, o relacionamento virtual existe, e gera conseqüências jurídicas.
} 
de sons e imagens ou o recurso a inovações tecnológicas especialmente criadas para o efeito. ${ }^{203}$

Falar que não houve relação sexual é sempre uma boa defesa, mas é grave dividir uma parte significativa da vida emocional com alguém e criar um vínculo que exclua o marido ou a mulher. A criação deste vínculo de cumplicidade com um estranho é, geralmente, o primeiro passo para a traição. É impossível estimar com certeza quantos casos virtuais se tornam reais. ${ }^{204}$

Assim, é certo que não existe a presença física, mas também é certo que existe recíproco prazer sexual.

Cabe também ressaltar que, ao mesmo tempo, a Internet despertou nas pessoas um ciúme desmedido, uma vez que permite que se vigiem coisas que sempre estiveram trancadas na privacidade de cada um. Cresce o ambiente de "paranóia eletrônica": cônjuges inseguros passam a espionar mensagens, investem contra o outro no Orkut e chegam a usar programas de hackers. ${ }^{205}$

\subsection{Enquadramento Jurídico}

O Direito se depara com um novo comportamento social, que até então não possuía parâmetros. Como enquadrar este tipo de atitude no ordenamento jurídico? Entender o romance sem sexo envolve conceitos subjetivos, trata-se de uma infidelidade emocional.

Alguns afirmam que nestes casos não se configura uma infidelidade real, por isso não teria conseqüências práticas. São aqueles defensores de que não há traição sem contato físico, sem a conjunção carnal.

Assim, há quem sustente posição frontalmente contra, afirmando que não pode haver infidelidade virtual porquanto "o adultério exige o contato físico e a prova

\footnotetext{
${ }^{203}$ Uma empresa americana criou um hardware chamado Genital Drive. É um aparelho de informática anatômico que reproduz fielmente os órgãos sexuais humanos (uma vagina ou um pênis), seria um simulador de cópula virtual, todos os movimentos e ações executadas pelos indivíduos são registrados pelo sistema e reproduzidos, em tempo real, para as unidades. Existe até mesmo a simulação da ejaculação.

204 Segundo um estudo da Universidade da Flórida, 30\% dos relacionamentos virtuais transferem-se para fora da Internet, permitindo aos intervenientes viver no mundo real as experiências partilhadas no mundo cibernético. Disponível em: <http://www.estadao.com.br/rss/tecnologia/2005/ago/31/168.htm>. Acesso em: 10 ago. 2006. Segundo a revista americana Psychology Today, estudos recentes indicam que em $60 \%$ dos casos, a infidelidade virtual termina em sexo real. Fonte: Revista Veja, "Traição Virtual: a nova modalidade de infidelidade é pela internet - e tumultua a vida dos casais”; Edição 1940, ano 39, n.3 - 25 de janeiro de 2006, Editora Abril.

${ }^{205} \mathrm{O}$ acesso ilimitado a contato com parceiros virtuais é contrabalançado pela possibilidade da parte que se sente enganada partir para a espionagem eletrônica. As crises de ciúme são praticamente inevitáveis.
} 
inconteste da ação, o que achamos impossível nas relações cibernéticas, onde o espaço virtual é tão etéreo como um amor platônico". ${ }^{206}$

Alguns afirmam que o problema apenas "ingressa na seara jurídica quando os internautas vêm a se conhecer pessoalmente, passando o relacionamento do mundo virtual para o real". ${ }^{207}$

Entretanto, este tipo de comportamento tem um potencial tão devastador para um relacionamento que pode afetá-lo, da mesma forma que se um dos cônjuges tivesse literalmente pego o outro na cama. Classificar uma conversa por e-mail como infidelidade pode parecer exagero, mas o resultado é o mesmo.

Assim, somos partidários da posição sustentada por Regina Beatriz Tavares da Silva, que afirma: "é evidente o retrocesso daqueles que concluem que a infidelidade virtual não seria descumprimento desse dever, por inexistir relação sexual no plano virtual. Há muito o Direito evoluiu para concluir que na infidelidade importa a busca de satisfação sexual fora do par conjugal, e não a relação sexual propriamente dita, que pode ou não existir". ${ }^{208}$

De forma similar, sustenta Cortiz da Silva que "os adultérios tradicional e virtual possuem o mesmo fim, que é a satisfação da libido, a sensação de prazer sexual com parceiro que não seja o seu cônjuge. A única diferença é o modus operandi" ${ }^{209}$.

Assim, "o dever de fidelidade não é descumprido somente pela relação sexual do cônjuge com terceira pessoa (...) Quando não havia a Internet, a comunicação por carta de uma pessoa casada com outra já era tida como infidelidade". ${ }^{110} \mathrm{O}$ que se diz ou se faz na Internet, portanto, não difere muito do que ocorria nos amores vividos através de cartas ou telefone.

\footnotetext{
${ }^{206}$ BRASIL, Angela Bittencourt. O adultério na Internet. Disponível em: <http://www1.jus.com.br/doutrina/ imprimir.asp?id=1832> ou <http://www.advogado.com/internet/zip/adulterio.htm>. Acesso em: 17 maio 2005. Entretanto, relacionamento virtual não é igual ao amor platônico. Virtual, segundo o Dicionário Aurélio, é o “que existe como faculdade, porém sem exercício ou efeito atual”. É algo suscetível de se realizar, que tem todas as condições essenciais à realização, que está predeterminado à realização, mas que é apenas potencial. Segundo o mesmo Dicionário, platônico significa “alheio a gozos materiais". FERREIRA, Aurélio Buarque de Holand. op. cit.

${ }^{207}$ VIEIRA, Tereza. Adultério virtual e infidelidade conjugal na Internet. Disponível em: < http://www.unitoledo. br/intertemas>. Acesso em: 29 maio 2006.

${ }^{208}$ SILVA, Regina Beatriz Tavares da. Débito conjugal. cit., p. 533.

${ }^{209}$ SILVA, Denis Cortiz da. Do adultério virtual. Disponível em: <http://jus2.uol.com.br/doutrina/texto. asp?id=6973>. Acesso em: 29 maio 2005.

${ }^{210}$ Entrevista concedida à Folha de São Paulo: SILVA, Regina Beatriz Tavares da. Recusa ao sexo pode gerar indenização. Disponível em: <http://www1.folha.uol.com.br/folha/brasil/ult96u27922.shtml>. Acesso em: 17 maio 2005.
} 
Como dito anteriormente, a fidelidade envolve o dever de lealdade entre os partícipes, sob o aspecto físico e moral, no sentido de abster-se de manter relações sexuais com terceira pessoa, e mesmo de praticar condutas que indiquem esse propósito ainda que não consumam a traição. ${ }^{211}$

No entendimento de Caio Mário da Silva Pereira: "a jurisprudência e a doutrina criaram o conceito de 'infidelidade moral', a qual não é tomada em sentido estrito, senão como injúria grave relativa à separação judicial contenciosa" 212 .

Portanto, a distinção entre a infidelidade material e moral importa para caracterizar a infidelidade virtual. Na relação virtual estabelece-se um laço erótico-afetivo platônico, mantido à distância através de um computador. Acontece um quase-adultério, uma infidelidade moral. ${ }^{213}$ Se isso levar ao contato físico, com relações sexuais, então acontece a infidelidade material ou adultério.

Assim, a infidelidade virtual é um relacionamento erótico-afetivo mantido através da Internet. O indivíduo casado ou unido estavelmente que, ao mesmo tempo, mantenha um relacionamento virtual está praticando infidelidade virtual. Se este relacionamento levar a relações sexuais, consuma-se o adultério. Ou seja, a infidelidade virtual somente se transformará em adultério se houver a materialização do relacionamento. Qualquer uma das hipóteses interessa ao Direito, porque configuram infração do dever de fidelidade, podendo causar a dissolução do casamento.

Este comportamento, na realidade, configura o chamado "quase-adultério". Já expusemos que para configurar o adultério é necessário provar a conjunção carnal. A figura jurídica do quase-adultério, por sua vez, significa toda situação amorosa na qual não se prova o sexo, mas sim o envolvimento amoroso, e isso é considerado infração do dever de fidelidade, tendo as mesmas conseqüências. ${ }^{214}$

\footnotetext{
${ }^{211}$ Nas palavras de Regina Beatriz Tavares da Silva: “a fidelidade é o dever de lealdade, sob os aspectos físico e moral, de um dos cônjuges para com o outro, quanto à manutenção das relações que visem à satisfação do instinto sexual dentro da sociedade conjugal. Nesse conceito não é apenas o adultério, relação carnal fora do casamento, que caracteriza o descumprimento desse dever. Todo ato que tenha em vista satisfazer aquele instinto, como o namoro do cônjuge com terceira pessoa, é havido como infração ao dever de fidelidade, mesmo sem chegar à cópula carnal". SILVA, Regina Beatriz Tavares da. Responsabilidade civil dos cônjuges . cit., p. 128.

${ }^{212}$ PEREIRA, Caio Mário da Silva. Instituições de direito civil: direito de família. 14. ed. Rio de Janeiro: Forense, 2004, p. 171. v. 5.

${ }^{213}$ Portanto, viola o dever de fidelidade não só o cônjuge que mantém relações sexuais com terceiro, mas também aquele que convive amorosamente com outra pessoa ou a ela se liga sentimentalmente, afetivamente, o que caracteriza a infidelidade moral.

214 "Muito embora não haja adultério quando um dos cônjuges se debruça durante horas envolvido nas palavras de alguém que está distante e que nem conhece pessoalmente, o Direito brasileiro reconhece a figura do quaseadultério, ou seja, uma espécie de tentativa, quando o adultério não se completa com a conjunção carnal, mas
} 
Por fim, não falta quem sustente que em todos esses casos há uma violação do dever de respeito. ${ }^{215}$ Assim dispõe Caio Mário da Silva Pereira: "fala-se, hoje, em 'infidelidade virtual' onde os relacionamentos extramatrimoniais dão-se no universo da informática, especificamente via Internet, o que não deixa de caracterizar uma atitude de efetivo desrespeito ao outro cônjuge". ${ }^{216}$ É certo que todas as violações do dever de fidelidade estão relacionadas, cumulativamente, a violações do dever de respeito, mas o contrário não ${ }^{217}$.

Portanto, as respostas para as perguntas que inicialmente fizemos não são tão simples. Entendemos que grande parte está na esfera subjetiva de cada um. ${ }^{218} \mathrm{Ou}$ seja, o relacionamento virtual será considerado infidelidade, suscetível de proceder a uma ação de divórcio, dependendo do ponto de vista do outro consorte. Para alguns, a visita esporádica, ou mesmo freqüente, a esses chats, bem como a troca de e-mails pode ser tolerada, enquanto que, para outros, basta uma única vez. O relacionamento humano é subjetivo, não se pode determinar de antemão o que irá comprometer, de fato, a vida em comum de um casal.

Portanto, é de se notar que as novas tecnologias dão margem a uma série de condutas que podem ser consideradas violadoras de deveres conjugais, gerando graves efeitos jurídicos. O que importa é que o sistema jurídico vigente autoriza o pedido unilateral de separação ao cônjuge que foi vítima de infidelidade moral, como é a infidelidade virtual, porque se trata do descumprimento de um dever legal, que é considerado injúria grave.

\subsection{Infidelidade Virtual ou Adultério Virtual?}

"Se um cônjuge vive enredado nas salas de bate-papo, relaciona-se virtualmente com alguém e passa longas horas diante do computador embevecido com as palavras que lê na tela anteposta diante de si e, com isso, esquece-se dos deveres

\footnotetext{
fica no limiar da conduta leviana que é infamante ao cônjuge inocente. Nestes casos, em que o adultério não se completa, porque não houve conjunção carnal, o comportamento pode ser ensejador de grave infração dos deveres do matrimônio". SANTOS, Antonio Jeová. op. cit., p. 204.

${ }^{215}$ Nas palavras de Fernando Brandão Ferreira Pinto: "Não é, assim, o dever de fidelidade mais do que uma faceta do dever de respeito, no qual está incluso. Infringe-se o dever de fidelidade quando se desrespeita o outro cônjuge em domínios ligados à sexualidade". PINTO, Fernando Brandão Ferreira. op. cit., p. 67. Mesmo que não se considerasse essa atitude como infidelidade conjugal, o namoro virtual fere o dever de consideração e respeito mútuos entre os cônjuges, que torna insuportável a vida em comum.

${ }^{216}$ PEREIRA, Caio Mário da Silva. op. cit., p. 171.

${ }^{217}$ Cf. SILVA, Hugo Lança. op. cit., p. 22.

${ }^{218}$ É compreensível o desconforto causado ao cônjuge por parte daquele que flertou com alguém na Internet, afinal a consideração e o respeito possuem caráter subjetivo.
} 
conjugais; se tal cônjuge participa do chamado 'sexo virtual', pode ser considerado adúltero na acepção jurídica do vocábulo?". 219

Se o adultério significa a conjunção carnal, e virtual é aquilo que não é carnal, conclui-se que este termo não deve ser utilizado. Melhor falar em infidelidade virtual, que entra na categoria de conduta desonrosa, ${ }^{220}$ incompatível com a fidelidade recíproca que é dever do casamento.

Portanto, tecnicamente, a expressão correta é infidelidade virtual. Não existe adultério virtual e sim infidelidade virtual, que pode levar ao adultério propriamente dito.

Havia muita discussão na doutrina a respeito da possibilidade de configuração do adultério virtual como crime. Nas palavras de Antonio Jeová Santos: "para a existência do adultério, é necessário o coito, vagínico ou-não. Assim sendo, não existe adultério no só fato de alguém praticar sexo virtual na Internet. A ausência do conúbio carnal retira a característica do adultério." 221

Também opina Ângela Bittencourt Brasil: "se partirmos da realidade de que entre duas pessoas existe um equipamento de hardware e que essas pessoas não têm qualquer contato físico, não poderíamos falar em adultério (...) No entanto, se olharmos sob a ótica de atos inequívocos que levam ao prazer sexual (...) poderia ser uma tese aceitável, pois são inúmeros os meios de encontros para este fim disponibilizados pela rede." 222

Assim, se no âmbito penal não era possível falar-se em adultério virtual, na esfera cível é possível considerar-se a infidelidade virtual.

Os romances virtuais, sob a ótica civil, já eram tratados pela doutrina sob a figura do "quase-adultério", isto é, qualquer forma de relacionamento que não chega à prática sexual propriamente dita.

Portanto, no âmbito civil a questão assume proporções mais significativas, ao considerar a materialização da infidelidade moral pela manutenção de um laço afetivoerótico na Internet, ensejando não-só a separação judicial, mas também a reparação de danos, cabendo ao juiz apreciar a gravidade da injúria.

\footnotetext{
${ }^{219}$ SANTOS, Antonio Jeová. Dano moral na Internet. São Paulo: Método, 2001. p. 202-203.

${ }^{220}$ Note-se que é difícil a configuração da conduta desonrosa, sendo esta uma expressão imprecisa e pouco objetiva. É desonrosa toda conduta que revele menosprezo ao ambiente familiar ou no meio social em que vive o casal, por exemplo.

${ }^{221}$ SANTOS, Antonio Jeová. op. cit., p. 203.

${ }^{222}$ BRASIL, Angela Bittencourt. O adultério na Internet. Disponível em: < http://www1.jus.com.br/doutrina/ imprimir.asp? $\mathrm{id}=1832>$ ou $<\mathrm{http}$ :/www.advogado.com/internet/zip/adulterio.htm>. Acesso em: 17 maio 2005.
} 
Além disso, tendo sido recentemente retirado do Código Penal, a discussão perdeu fundamento, prevalecendo a idéia já aceita pela maioria dos doutrinadores, de que se configura a infidelidade virtual. Portanto, não há mais por que questionar a respeito do adultério virtual, já que este deixou de ser crime.

\subsection{Conclusões}

Por tudo o que aqui expusemos, concluímos que a infidelidade virtual existe e pode ser causa para o divórcio, devendo aquela relação subsumir-se à noção de infidelidade moral.

A prática da ciberinfidelidade é, por certo, uma conduta que afronta a moral, e, por conseqüência, os deveres de fidelidade recíproca e respeito mútuo.

Importante ressaltar, novamente, que a traição não é apenas o contato físico, mas também a intimidade emocional, as confidências e fantasias. Entendem alguns que a infidelidade afetiva é mais grave que a sexual, tem maior poder de destruição, visto que o parceiro já não demonstra mais a mesma vivacidade no afeto.

A Igreja Católica recentemente se posicionou a respeito da questão: "a traição por e-mail e contatos sexuais imaginários são tão condenáveis quanto os condenáveis encontros físicos".223

A nosso ver, as relações afetivo-sexuais desenvolvidas via internet não são patológicas. Assim, cabe esclarecer que não consideramos os apologistas de relacionamentos virtuais adúlteros típicos. Geralmente são pessoas que buscam extravasar, no mundo virtual, seus desejos e fantasias, acreditando que isso não irá comprometer seu vínculo conjugal. Como dito anteriormente, na maioria dos casos, quem tem "amantes virtuais" entende, convictamente, que não está violando o dever de fidelidade recíproca. Entretanto, a conseqüência natural é a revolta causada pela falta de lealdade.

Portanto, no que concerne à infidelidade virtual, está é uma realidade que invade domicílios conjugais com comprovados efeitos na vida matrimonial. Além de ser de uma comodidade absoluta, já que sequer é preciso sair de casa para consumá-la.

A prática profissional já demonstra a existência de diversos casos de relacionamentos iniciados pela Internet. ${ }^{224}$ Nos últimos anos, o número de consultas aos

\footnotetext{
${ }^{223}$ DAOUN, Alexandre Jean. $O$ adultério virtual. Disponível em: <http://jus2.uol.com.br/doutrina/texto. asp? $\mathrm{id}=2564>$. Acesso em: 29 maio 2006.

${ }^{224}$ Nos grandes escritórios de advocacia, em $90 \%$ das separações são apresentadas cópias de e-mails e mensagens de Messenger e Orkut para configurar o que se chama de "quase-adultério". Fonte: Revista Veja, "Traição
} 
advogados sobre a traição virtual aumentou. Muitos são os cônjuges preocupados com a configuração ou-não da infidelidade virtual.

O problema é evidente: o uso da Internet já se tornou um dos assuntos inevitáveis na vida de um casal.

\subsection{Possibilidade do Dano Moral na Infidelidade Virtual}

O dano moral é todo sofrimento humano que não é causado por uma perda pecuniária. É o dano não-patrimonial, que atinge a pessoa como ser humano, sua honra. ${ }^{225}$

“No atual momento socioeconômico brasileiro, muitos têm sido os processos que pleiteiam indenização por dano moral na esfera cível. Contudo, na esfera familiar tais pedidos reclamam uma profunda reflexão e investigação das verdadeiras motivações do autor. Um pedido de indenização somente não será imoral se houver um dano realmente grave e a reivindicação não tiver por objeto apenas o lucro fácil'". ${ }^{226}$ A prosperar este exagero, praticamente toda a ação de separação judicial ensejaria pedido cumulado de perdas e danos morais.

Na separação de um casal ocorrem perdas emocionais, trata-se da morte de um projeto a dois. Tudo o que depositamos em nossos parceiros é o reflexo de nosso próprio desejo de completude. Assim, cada um quer ser indenizado pelo prejuízo sofrido em nome do amor que acabou. ${ }^{227}$

Virtual: a nova modalidade de infidelidade é pela internet - e tumultua a vida dos casais"; Edição 1940, ano 39, n. 3 - 25 de janeiro de 2006, Editora Abril.

225 "A honra tem dois aspectos: subjetivo e objetivo. No primeiro, define-se como a auto-estima ou consciência da própria dignidade e, no segundo, como a consideração social. A ofensa à honra pode ser real, quando praticada por meio de gestos ou atos, e verbal, quando perpetrada por palavras". SANTOS, Regina Beatriz Tavares da Silva Papa dos. Responsabilidade civil dos cônjuges. cit., p. 130. O sofrimento moral tem suas variantes no dano efetivo e no trauma social. O conceito de dano moral contempla a esfera da subjetividade e o conceito de que goza a pessoa na sociedade, em que reflete o fato violador, ou seja, aqueles que alcançam os aspectos mais intrínsecos da pessoa humana (o da intimidade e da consideração pessoal), ou da própria valoração da pessoa humana no ambiente em que convive e age (o da reputação e da consideração pessoal). Nesse sentido, BITTAR, Carlos Alberto. Reparação civil por danos morais. São Paulo: Revista dos Tribunais, 1993. p. 41.

${ }^{226}$ GUIMARÃES, Marilene Silveira. Adultério virtual, infidelidade virtual. In: II CONGRESSO BRASILEIRO DE DIREITO DE FAMÍLIA - IBDFAM. A família na travessia do milênio. Belo Horizonte: Del Rey, 2000. p. 451.

227 "Começamos falando de amor e terminamos sempre falando de dinheiro. Realidade difícil, mas compreensível se entendermos o caminho trilhado desde o sonho construído a dois, no qual o par se basta para viver na mais plena felicidade, e percorremos todas as decepções, chegando às necessárias indenizações que cada um sente merecer por ter sido enganado, ludibriado, traído." MOTTA, Maria Antonieta. op. cit., p. 40. 
É preciso esclarecer que o desamor, por si só, não é causa de aplicação dos princípios da responsabilidade civil, já que, mesmo ao acarretar sofrimento ou dano moral ao desamado, não constitui ato ilícito, por não-contrariar qualquer norma jurídica, faltando-lhe, portanto, requisito essencial da reparação civil. ${ }^{228}$ Portanto, cabe esclarecer que em determinados casos, mesmo havendo o prejuízo causado, não há a imputação do dever de indenizar. ${ }^{229}$

Não é a idéia de culpa que fundamenta essa tese, mas sim a da reparação civil, pela prática de ato ilícito que acarreta dano a outrem. Assim, as relações entre os cônjuges, reguladas pelo Direito de Família, são plenamente alcançáveis pelos princípios da responsabilidade civil. Ao colocar-se o casamento em um plano superior, na verdade deixa-se de oferecer proteção aos cônjuges. ${ }^{230}$

Dessa forma, embora se reconheça a moderna tendência que atribui à separação e ao divórcio caráter de "remédio", não se pode olvidar que em alguns casos o fim do conflito conjugal pode causar muitos prejuízos, de ordem moral e material, que não devem ficar sem reparação. ${ }^{231}$

Pois bem, se um dos cônjuges, com sua conduta, descumpre um dever conjugal, em algumas hipóteses específicas poder-se-á aplicar os princípios da responsabilidade civil. 232

\footnotetext{
${ }^{228}$ Nas palavras de Regina Beatriz Tavares da Silva: "nosso pensamento jamais se voltou à aplicação dos princípios da responsabilidade civil pelo mero fim do casamento. Em tempo algum dissemos ou escrevemos que a falta de amor ou as frustrações do fracasso conjugal possam gerar a reparação de danos". SILVA, Regina Beatriz Tavares da. Débito conjugal. In: IV CONGRESSO BRASILEIRO DE DIREITO DE FAMÍLIA - IBDFAM. Afeto, ética, família e o novo código civil. Belo Horizonte: Del Rey, 2004. p. 539.

${ }^{229}$ Há uma grande dificuldade em se definirem os requisitos essenciais para a configuração da responsabilidade. Maria Helena Diniz expõe que são três os elementos: uma ação ou omissão; um dano patrimonial ou moral; e o liame entre os dois primeiros. (DINIZ, Maria Helena. Curso de direito civil brasileiro. São Paulo: Saraiva, 1993. v. 7, p. 30). É necessária a consciência do ato faltoso, ou a voluntariedade na violação do dever.

${ }^{230}$ No Direito brasileiro, diante da legislação vigente, é descabida qualquer interpretação que impeça a aplicação dos princípios e regras sobre a responsabilidade civil à dissolução da sociedade conjugal. É desejável que os tribunais acolham as demandas cujos pleitos indenizatórios se referem aos danos decorrentes do grave descumprimento do dever conjugal, o que, se não constituir um freio aos rompimentos matrimoniais, aliviará a situação do cônjuge lesado. Cf. SANTOS, Regina Beatriz Tavares da Silva Papa dos. Responsabilidade civil dos cônjuges. cit., p. 138.

${ }^{231}$ Cf. SANTOS, Regina Beatriz Tavares da Silva Papa dos. Responsabilidade civil dos cônjuges. cit., p. 138.

232 “A lei, ao estabelecer deveres aos cônjuges, obriga-os à prática de certos atos e à abstenção de outros. Uma vez violados esses deveres, com a ocorrência de danos, surge o direito do ofendido à reparação, em razão do preenchimento dos pressupostos da responsabilidade civil - ação, dano e nexo causal -, assim como ocorre diante da prática de ato ilícito em outras relações jurídicas". SANTOS, Regina Beatriz Tavares da Silva Papa dos. Responsabilidade civil dos cônjuges. cit., p. 133. Assim, é especificamente na extinção da sociedade conjugal, oriunda de violação a dever dos cônjuges, que surge a possibilidade de aplicação dos princípios da responsabilidade civil.
} 
Hoje, a doutrina e jurisprudência divergem quanto à reparação do dano pela simples ruptura do vínculo, mas há casos, dependendo da forma como essa ruptura se deu, em que pode surgir uma indenização. ${ }^{233} \mathrm{Ou}$ seja, nada impede que, no momento da dissolução, tenha um dos cônjuges praticado um ato ilícito que venha a causar prejuízo moral ou material ao outro, mesmo que este ato seja o motivo da ruptura do vínculo. Se assim ocorrer, deve esse dano ser ressarcido.

Assim, "quem rompe uma relação de casamento ou de união estável por falta de amor está exercendo regularmente um direito, que é o de separar-se, sendo esta uma excludente da responsabilidade civil'. ${ }^{234}$ Entretanto, há que se atentar para a forma como isso ocorre, para que não haja nenhuma conduta ilícita ou prejudicial a qualquer das partes. Ou seja, há de se perquirir as causas da separação e como ocorreu este processo, pois qualquer relacionamento humano pode ser o móvel de uma reparação de dano moral.

A infidelidade é uma circunstância normalmente intolerável para a vida em comum. Mas não caberia o dano moral puro, como alguns pretendem sustentar, a menos que venha acompanhada de violência física ou moral ou de humilhação contínua diante de terceiros ou dos próprios filhos. Nestes casos nos encontraremos no âmbito do ilícito e haverá responsabilização pelo dano moral infringido. ${ }^{235}$ Portanto, não se admite que o conceito jurídico de dano moral deva se configurar a partir das noções de sofrimento, tristeza - porque tais sentimentos estarão presentes em praticamente todos os conflitos que surgem nos relacionamentos conjugais. ${ }^{236}$ Como em todas as demais relações existenciais, onde tiver havido lesão à igualdade, à integridade psicofísica, à liberdade e à solidariedade terá havido dano moral indenizável. ${ }^{237}$

\footnotetext{
${ }^{233}$ Os tribunais têm-se mostrado em prol da ressarcibilidade do prejuízo moral decorrente da ofensa praticada pelo cônjuge contra a honra do seu consorte. Independentemente das outras sanções.

${ }^{234}$ SILVA, Regina Beatriz Tavares da. Débito conjugal. cit., p. 539. O uso normal de um direito, embora possa causar danos morais ou materiais, não configura ato ilícito.

${ }^{235}$ Cf. MORAES, Maria Cecília Bodin. Danos morais e relações de família. In: IV CONGRESSO BRASILEIRO DE DIREITO DE FAMÍLIA - IBDFAM. Afeto, ética, familia e o novo código civil. Belo Horizonte: Del Rey, 2004. p. 399-415.

Assim o relacionamento extraconjugal não configura, por si só, o dano moral. Para que se possa conceder o dano moral é preciso mais que um simples rompimento da relação conjugal, mas que um dos cônjuges tenha, efetivamente, submetido o outro a condições humilhantes, vexatórias e que lhe afronte a dignidade, a honra ou o pudor. Nas palavras de Sônia Maria Teixeira da Silva, "a traição fere os direitos concernentes aos valores próprios do ser humano, que se projetam nos seus sentimentos". A mesma prossegue "a traição resultará em dano moral se levar o nome do traído a situações embaraçosas, vexatórias; se a presença do ofendido provocar zombarias, menosprezo". SILVA, Sônia Maria Teixeira da. Traição e dano moral. Disponível em: <http:// www.direitovirtual.com.br/print/print.php?page=artigos\&id=165>. Acesso em: 29 maio 2006.

${ }^{236} \mathrm{O}$ sofrimento que o rompimento acarreta aos cônjuges é um dano indireto e, portanto, não indenizável.

${ }^{237}$ São exemplos de danos diretos ou imediatos e indenizáveis aqueles decorrentes da transmissão de doença contagiosa ao cônjuge, da sevícia ou lesão corporal, da injúria, da infidelidade etc. Tais danos são morais
} 
Mas que critérios seriam adotados para a avaliação do dano? Como estimar em dinheiro o preço do adultério, por exemplo? Antes de tudo, é preciso reconhecer que o dinheiro não compensa a afeição perdida. Dinheiro e dor não podem ser sopesados por igual, afinal a dor não tem preço. Dessa forma, a reparabilidade não objetiva a vingança do traído, mas sim recompensar o dano imaterial sofrido pela vítima. ${ }^{238}$

Neste contexto, acreditamos que a infidelidade virtual pode gerar responsabilização e indenização, em determinadas circunstâncias excepcionais, quando atinge a integridade psíquica de um dos cônjuges, já que nos aproximamos do princípio da dignidade humana. ${ }^{239}$

Assim, nas palavras de Antonio Jeová Santos, "o cônjuge não participante da orgia informática, pode pleitear indenização por dano moral. Apesar da não existência do adultério stricto sensu, o comportamento de quem se dedica a manter sexo virtual ou de quem procura parceiros ou parceiras para um futuro encontro em três dimensões é agravante ao companheiro que de nada participa dessas aventuras levadas a cabo pela Internet. Será motivo de menoscabo espiritual, deixar o marido ou a mulher de dar atenção real e voltar-se às companhias virtuais". ${ }^{240} \mathrm{O}$ mesmo autor prossegue afirmando que "é de índole dolorosa e acentuada a prática do quase-adultério, a injúria consistente em permanecer em salas de chat destinadas a sexo virtual, causando mortificações ao outro cônjuge. Desde que estas condutas desviantes do parceiro sejam martirizantes e causem angústia e mal-estar espiritual, o dano moral aparece resplandecente, em toda a sua grandeza". ${ }^{241}$

por atingirem os direitos da personalidade do lesado à vida, à integridade física e à honra; e em alguns casos podem ter natureza material. Cf. SANTOS, Regina Beatriz Tavares da Silva Papa dos. Responsabilidade civil dos cônjuges. cit., p. 136.

${ }^{238}$ Nesse sentido, BELINCANTA, Fernando César; LOPES, Fernando Augusto Monati y. A possibilidade da compensação do dano moral na separação conjugal. Disponível em: < http://jus2.uol.com.br/doutrina/texto. asp?id=3743>. Acesso em: 29 ago. 2006.

${ }^{239}$ A dignidade é um atributo do homem, nasce com ele, que tem de viver de forma digna. Ela não pode ser perdida, mesmo quando a própria pessoa pratica ato tido como indigno. A dignidade do homem guarda incomensurável e necessário conteúdo ético. Aviltante é o comportamento de quem atenta contra essa qualidade que deve ser resguardada ao ser humano. Qualquer ato tendente ao menoscabo da dignidade há de merecer repulsa e a devida correção, com a reparação do dano moral na esfera civil, que o ato comprometedor da dignidade sempre acarreta.

${ }^{240}$ SANTOS, Antonio Jeová. Dano moral na Internet. São Paulo: Método, 2001. p. 203.

241 "Se marido e mulher vivem em distância inconciliável, não a distância geográfica medida por quilômetros, mas aquela suficiente para deixar o cônjuge ao abandono quando ambos estão no mesmo lar, mas esquecido porque o outro prefere os chats, a infração ao dever de fidelidade é inelutável; o dano moral, também". Id. Ibid., p. 205. 
Portanto, em relação ao outro, o cônjuge sempre tem como referência que exista fidelidade. E esse direito pode ser exigido, sob pena de ser maculada a honra daquele que se sentir ofendido por adultério ou quase-adultério. É passível de indenizar por dano moral aquele que procura sexo virtual ou companhias na Internet, sem a anuência do outro cônjuge. "É danoso o ato de quem, tendo cônjuge, não se peja em permanecer horas a fio entretido na Internet à cata de sexo virtual ou de alguém que, futuramente, pode encontrar pessoalmente, seja para uma fugaz aventura ou para algo mais duradouro e sério."242

Além disso, na infidelidade virtual, quando o cônjuge adúltero expõe na Internet essa condição, injuriando ou difamando o outro, fica ainda mais claro que caberia a reparação dos danos morais.

Entretanto, no que diz respeito à quantificação do dano moral causado pela divulgação de conteúdo ofensivo na Internet, é preciso atentar que a possibilidade de acesso ao material lesivo por qualquer pessoa, a qualquer tempo, não autoriza concluir que o dano efetivamente causado à vítima seja de enormes proporções. Ou seja, ainda que a informação possa ser acessada por qualquer pessoa, isto não significa que ela tenha sido de fato vista por milhares de usuários. ${ }^{243}$

A infidelidade virtual, portanto, poderá ser argüida como causa para separação judicial litigiosa e, ainda, para a indenização de danos morais.

Tudo isso importa na aproximação entre o Direito e a Moral, desejável especialmente no Direito de Família. ${ }^{244}$ A Moral e o Direito são ordenações inseparáveis. Todas as normas de Direito são, em última análise, normas morais.

${ }^{242}$ SANTOS, Antonio Jeová. Dano moral na Internet. São Paulo: Método, 2001. p. 203-204. “É injurioso o comportamento de marido ou de mulher que permanece horas a fio em salas de bate-papo à busca de companhia de pessoa do sexo oposto. Mesmo diante de costumes liberalizantes, típicos da nossa época, o adultério ou a prática de ato que configure infidelidade conjugal, é visto com repúdio e é execrado pela sociedade. Um dos substratos ônticos do ser humano é o respeito. Pode ser tachado de dissoluto o ato de quem - casado - se predispõe a abandonar o marido ou a mulher, mesmo que dentro do próprio lar, para se dar a embaraçosas ligações na Rede que buscam a simpatia do sexo oposto". Id. Ibid., p. 204. Cabe lembrar que também constitui injúria-grave o comportamento de marido ou mulher que busca companhia de pessoas do mesmo sexo na Internet, já que as uniões homossexuais fora do casamento são consideradas infração ao dever de fidelidade.

${ }^{243}$ Sendo assim, é importante, para a delimitação da extensão do dano, a análise dos registros de acesso e do volume de tráfego de dados do web site, o exame da própria natureza do web site, da forma como ele explora a divulgação de informações e ainda, o período de tempo em que as informações ofensivas permaneceram disponíveis na rede (sendo o dano, na maior parte dos casos, proporcional ao tempo de duração da divulgação do conteúdo lesivo). A prova dessas questões interessa ao demandado, a quem compete demonstrar que o dano causado ao autor não atingiu as proporções por ele alegadas.

${ }^{244}$ Cf. SANTOS, Regina Beatriz Tavares da Silva Papa dos. Responsabilidade civil dos cônjuges. cit., p. 138.

"Quando relacionamos com o termo Direito, a palavra Moral é substantivo feminino, e designa ordenação do comportamento (...) Em tese, poderia essa ordenação ser entendida como a ordenação efetivamente estabelecida pelos usos e costumes; e poderia ser entendida como a ordenação ideal do comportamento humano. (...) A 


\section{Aspectos Processuais}

Como advertimos no início deste artigo, procuraremos agora imprimir um aspecto mais prático à questão da infidelidade virtual, apontando possíveis caminhos para o operador do Direito seguir no desenvolvimento jurídico da questão.

\subsection{Meios de Prova e Provas Ilícitas}

Apesar de não ser tema específico deste artigo, entendemos ser necessário tratar da problemática relacionada à prova da infidelidade virtual.

"Pode-se dizer que a prova é elemento integrador da convicção do juiz com os fatos da causa, daí sua relevância no campo do direito processual." 245 Assim, de nada adiante afirmar sem provar. O bom direito a ser declarado pelo órgão jurisdicional não se compadece com a mera alegação das partes. Por isso a ampla oportunidade para o demandante aportar aos autos toda a prova necessária à comprovação do que alegou. Porém, o direito da parte de deduzir em juízo todas as provas relevantes à sua disposição não é absoluto. Há restrições.

Para realizar a prova da infidelidade virtual, o cônjuge esbarra em inúmeras dificuldades. ${ }^{246}$ Inicialmente, questiona-se a respeito da validade das provas apresentadas, dependendo do meio como foram obtidas. Também é preciso que se averigue quais as provas permitidas e quais aquelas consideradas ilícitas. ${ }^{247}$

ordenação ideal para a atividade livre do ser humano é, obviamente, a ordenação considerada perfeita para essa atividade. (...) A perfeição de um ser não é a perfeição absoluta (...) é a perfeição de um ser em seu estado de concluído, dentro da ordem ou categoria a que esse ser pertence”. TELLES JUNIOR, Goffredo. op. cit., p. 43-44.

${ }^{245}$ AVOLIO, Luiz Francisco Torquato. Provas ilícitas: interceptações telefônicas, ambientais e gravações clandestinas. 3. ed. São Paulo: Revista dos Tribunais, 2003. p. 25.

A prova tem como finalidade prática o convencimento do juiz, que é seu destinatário. Ela serve à formação do convencimento do juiz, sendo sustentáculo de uma decisão judicial.

${ }^{246} \mathrm{Na}$ realidade, a complexidade da prova não é especificidade da infidelidade virtual, mas da infidelidade em geral. O problema da prova da infidelidade surge porque, no mais das vezes, colide com a proteção legal do direito à intimidade. Em grande parte dos casos, os meios utilizados pelo cônjuge para descobrir a infidelidade do seu consorte são insuscetíveis de serem valorados em Tribunal.

${ }^{247}$ A Constituição Brasileira de 1988, ao dispor que "são inadmissíveis, no processo, as provas obtidas por meios ilícitos" (art. 5, inc. LVI), colocou a questão da inadmissibilidade no processo das provas ilícitas em termos aparentemente absolutos. Transferiu-se, assim, à doutrina e à jurisprudência compatibilizar aquelas exigências conflitantes, como o direito à prova-privacidade. Cf. AVOLIO, Luiz Francisco Torquato. op. cit., p. 24.

Segundo Ada Pellegrini Grinover, a prova ilícita enquadra-se no grupo da prova vedada, entendida esta como a prova contrária, em sentido absoluto ou relativo, a uma específica norma legal, ou a um princípio de direito positivo. GRINOVER, Ada Pellegrini. As nulidades no processo penal. 6. ed. São Paulo: Revista dos Tribunais, 2000. p. 11. 
A prova ilícita é prova inidônea. Mais do que isso, prova ilícita é prova imprestável. Não se reveste, por essa explícita razão, de qualquer aptidão jurídicomaterial. ${ }^{248}$ Portanto, a prova deve ser obtida por meios lícitos, que não contrariem a moral e os bons costumes, que esteja dentro dos limites éticos do homem.

A problemática pertinente às provas ilícitas torna-se mais delicada quando se refere ao Direito de Família, no qual repousam as relações familiares, a individualidade de cada membro da família, sua dignidade e intimidade. ${ }^{249}$ Questiona-se também “até que ponto essas provas obtidas unilateralmente têm idoneidade suficiente para serem aceitas no juízo da família?"250

Procederemos a este exame trazendo exemplos de situações fáticas, que melhor exprimem a questão, de forma mais objetiva e, portanto, esclarecedora. Ou seja, é importante caracterizar cada ato, pontualmente, para depois aplicar as mesmas conclusões ao caso específico da infidelidade virtual, de forma a estancar quaisquer dúvidas que possam surgir.

Assim, se um cônjuge abre a correspondência do outro, uma carta que foi deixada embaixo da porta, por exemplo, estaria configurada a violação de correspondência. ${ }^{251}$ Por outro lado, se esta carta, já aberta, fosse deixada ao alcance do outro cônjuge, em cima de uma mesa, e este viesse a lê-la, entendemos que não há violação de correspondência.

O mesmo exemplo pode ser transposto para o caso da infidelidade virtual, com a leitura de e-mails. Assim, se o cônjuge deixa seu computador particular ligado, com o e-mail comprometedor aberto na tela, não se configura violação de correspondência, pois o seu consorte não tomou nenhuma atitude para ter acesso a ele. Da mesma forma, se o

\footnotetext{
${ }^{248}$ Nesse sentido, BARBOSA, José Olindo Gil. As provas ilícitas no processo brasileiro. Disponível em: $<$ http:// jus2.uol.com.br/doutrina/texto.asp?id=8417>. Acesso em: 05 jun. 2006.

${ }^{249}$ Nesse sentido, LAWAND, Jorge José. O direito de família e a produção de provas. Disponível em: $<$ http:// www.boletimjuridico.com.br/doutrina/impressao.asp?id=544>. Acesso em: 29 maio 2006.

${ }^{250}$ Id. Ibid.

Destarte, se em ação civil, o cônjuge junta e-mail ou histórico do bate-papo impresso de correspondência trocada pelo outro cônjuge, onde se revela sua deslealdade, configura a justa causa, portanto não se caracteriza o crime de divulgação de segredo.

251 "Interceptar correspondência significa desvendar seu conteúdo antes que ela alcance o destinatário, o que constitui, ademais, crime de violação de correspondência”. AVOLIO, Luiz Francisco Torquato. Provas ilícitas: interceptações telefônicas, ambientais e gravações clandestinas. 3. ed. São Paulo: Revista dos Tribunais, 2003. p. 215 .

"O segredo, a impedir que certas manifestações de um dos cônjuges sejam conhecidas ou divulgadas pelo outro, também deve ser respeitado no casamento, por maior que seja a intimidade que se instala nessa relação. Não pode o cônjuge, por exemplo, violar a correspondência do consorte". SANTOS, Regina Beatriz Tavares da Silva Papa dos. Responsabilidade civil dos cônjuges. cit., p. 130.
} 
computador é de uso comum dos cônjuges, sendo que ambos tem acesso aos e-mails (não há senha ou a senha foi revelada entre eles), ${ }^{252} \mathrm{em}$ nenhuma hipótese estaria configurada a violação de correspondência pela leitura de um e-mail comprometedor. Por outro lado, se o computador for particular, ou se o e-mail for protegido por senha, e um dos cônjuges o acessa ou obtém a senha sem autorização do outro, essa atitude configura violação de correspondência, e as informações que obtiver não podem ser utilizadas como prova, já que foram adquiridas por meios ilícitos. ${ }^{253}$

Assim, nas palavras de Marilene Silveira Guimarães: "na hipótese de o cônjuge infiel manter a comunicação virtual através de computador de uso familiar, sem uso de senha, a obtenção desta prova através da entrada no correio eletrônico não pode ser considerada invasão de privacidade ou violação ao direito de sigilo, pois o usuário não tomou as devidas cautelas para preservar a sua intimidade. Porém, se o internauta usar senha de acesso e a prova for obtida sem o seu consentimento, ela será considerada ilícita". ${ }^{254}$

Também se questiona se a leitura de uma correspondência jogada no lixo, por um dos cônjuges, seria uma violação. Entendemos que não, pois aquilo que foi jogado fora pode ser visto por qualquer um, não haveria dolo da outra parte se, por acaso, no momento em que fosse descartar o lixo, lesse o conteúdo desse papel. Analogamente, o conteúdo da "lixeira" do computador, desde que este seja de uso comum dos cônjuges, pode ser acessado por qualquer um (os itens excluídos, inclusive e-mails, permanecem por um tempo neste arquivo), portanto se o cônjuge tomar ciência de seu conteúdo comprometedor, não estaria configurada a violação de correspondência.

Assim, a prova pode produzir-se por recurso a documentos eletrônicos, nomeadamente fotos, áudio ou vídeo e documentos escritos, existentes no computador do casal, e como tal suscetíveis de serem consultados e utilizados por qualquer dos cônjuges. Se inocente tiver acesso aos e-mails ou ao MSN do cônjuge infiel, ou mesmo se os indícios estiverem disponíveis na própria Internet, na rede, como no Orkut ou em páginas da Web, não haveria maiores problemas na realização dessa prova, bastando apresentar as cópias dos mesmos em juízo.

\footnotetext{
${ }^{252}$ Senhas são em geral consideradas sigilosas, e utilizar e acessar informação sigilosa pode ser crime, mas quando alguém espontaneamente cede ou informa a senha, aí deixa de haver crime, porque houve consentimento prévio para uso da informação sigilosa.

${ }^{253} \mathrm{Se}$ o computador for particular, ou existir senha para acessar os e-mails do outro cônjuge, e o inocente vier a ter acesso a eles ilicitamente, não poderá utilizá-los como prova, pois estaria configurada a violação de privacidade. Também entre os cônjuges existe o dever de respeito, e violar a correspondência seria uma forma de infração da privacidade.
}

${ }^{254}$ GUIMARÃES, Marilene Silveira. op. cit., p. 453. 
O computador registra as provas da suposta traição, por meio de mensagens recebidas e enviadas, registros de ICQ e MSN ou equivalente. Entendemos que o disposto nos arquivos poderá ser objeto de prova. A cópia do texto do e-mail pode ser um excelente meio de prova para comprovação da conduta desonrosa, pela web, de um dos cônjuges, ensejadora do fim da sociedade conjugal. Portanto, "o e-mail já transmitido e arquivado no disco rígido do computador poderia vir a ser utilizado como prova se entendido como documento e submetido à disciplina da busca e apreensão. O problema é a sua autenticidade, que ensejaria complexa perícia, se questionada pela pessoa contra quem se dirige a prova. Dificuldades técnicas, contudo, não constituem obstáculo para a admissibilidade desse meio de prova". ${ }^{255}$

Assim, questiona-se a validade dessas provas, uma vez que os documentos eletrônicos podem ser facilmente adulterados, tanto em seu conteúdo quanto em sua origem. ${ }^{256} \mathrm{Ou}$ seja, muitas vezes resta prejudicada a prova em face da não-integridade e autenticidade. Os e-mails, mandados ou recebidos, podem ser forjados até pelo cônjuge que se diz enganado. Caberá ao juiz, com o auxílio de um perito, se for o caso, analisar a sua veracidade. ${ }^{257}$

Nas palavras de Regina Beatriz Tavares da Silva, "um e-mail ou uma consulta a uma sala de 'bate-papo'virtual, ambos com o intuito de satisfação do instinto sexual com terceira pessoa, são provas da existência da infidelidade, assim como é a carta enviada pelo correio não eletrônico, ou era aquela remetida por meio do pombo-correio. Não há diferença entre o meio de comunicação, seja ou não eletrônico; ele servirá de prova da infidelidade". 258

Cabe lembrar que esses tipos de provas se tornaram comuns nos casos de separação. Em 90\% das separações, cópias de e-mails e mensagens de Messenger e Orkut são apresentadas para comprovar a infidelidade. ${ }^{259}$

${ }^{255}$ AVOLIO, Luiz Francisco Torquato. Provas ilícitas: interceptações telefônicas, ambientais e gravações clandestinas. 3. ed. São Paulo: Revista dos Tribunais, 2003. p. 215-216.

${ }^{256}$ Por intermédio dos recursos técnicos, é factível a mudança de documentos digitais sem deixar vestígios. Ao visitar um web site ou ler um e-mail, o usuário não tem como assegurar-se de que as informações apresentadas são realmente verdadeiras. Somente através dos provedores de serviços é que é possível conhecer os verdadeiros responsáveis pela transmissão, armazenamento e divulgação de dados e informações.

${ }^{257}$ O Poder Judiciário, ao se deparar com essas situações inusitadas, oriundas da informática, pode aplicar regras válidas para hipóteses semelhantes, utilizando como auxílio pareceres técnicos fornecidos por peritos da área de informática.

${ }^{258}$ SILVA, Regina Beatriz Tavares da. Débito conjugal. cit., p. 533-534.

${ }^{259}$ Fonte: Revista Veja, “Traição Virtual: a nova modalidade de infidelidade é pela internet - e tumultua a vida dos casais"; Edição 1940, ano 39, n. 3 - 25 de janeiro de 2006, Editora Abril. 
Há, também, a possibilidade de se comprovar a infidelidade virtual através de prova testemunhal, caso, por exemplo, uma terceira pessoa ou o próprio cônjuge traído flagre seu consorte nesta situação, ou seja, ele deve ser surpreendido no ato.

Por fim, um outro meio de prova possível, no caso das anteriores restarem infrutíferas, sendo também o mais recomendável, são os dados de conexão, ou registros de números de IP (Internet Protocol), utilizados durante o acesso à Internet, que ficam em poder dos provedores de serviços de Internet. ${ }^{260}$ Como explicado anteriormente, estes registros contêm informações relativas ao uso da rede, tais como datas e horários de login e logout, nome de usuário utilizado, e demais informações técnicas. ${ }^{261}$ Não englobam, portanto, o conteúdo das comunicações, nem as transmissões de dados realizadas pelos usuários, mas apenas os dados vinculados a sua identificação na Internet.

O cônjuge poderia requisitar esses registros ao provedor ${ }^{262}$ e levá-los em juízo, comprovando a existência de um relacionamento, ou pelo menos do contato freqüente entre o seu consorte e uma terceira pessoa, estranha ao lar conjugal. Seria uma espécie de prova indireta, pois não restará comprovado o teor dos e-mails trocados, mas apenas indícios do envolvimento.

Sendo a prova indireta, apenas indícios de que o cônjuge mantinha um relacionamento com outra pessoa, ou outras pessoas, o que não evidencia o conteúdo dos e-mails, há, de certa forma, uma vantagem, pois o cônjuge infiel não pode alegar invasão de sua privacidade. ${ }^{263}$ Cabe ao juiz ouvir as partes e questionar a respeito desses indícios, tirando suas próprias conclusões.

\footnotetext{
${ }^{260}$ Quando um usuário se conecta à Internet, recebe um numero único de identificação na rede, conhecido como IP. O registro dessa conexão é automaticamente efetuado pelo seu provedor de acesso. Portanto, quase tudo o que se faz na Internet gera um registro da atividade realizada, sendo tal procedimento inerente ao próprio funcionamento da rede. Assim, devem os provedores de serviços utilizar meios tecnológicos e equipamentos informáticos que possibilitem a identificação dos dados de conexão dos usuários, para que tais informações sejam disponibilizadas a quem de direito em caso de ato ilícito. É preciso quebrar o sigilo da base de clientes para se identificar o usuário daquele IP.

${ }^{261}$ Dados de conexão se referem à identificação da origem da transação e seu destinatário, horários de início e conclusão da transação, e ao número de telefone ou identificação do ponto de rede utilizado para efetuar a conexão.

${ }^{262} \mathrm{O}$ direito à privacidade não é absoluto, e encontra exceções quando o usuário pratica ato ilícito, hipótese que autoriza o fornecimento, pelo provedor de serviços, de seus dados de conexão a terceiros e as autoridades competentes.

${ }^{263}$ Sobre o assunto, Antonio Jeová Santos menciona que "naqueles casos de foro fechado, como os chats, fórum de discussão, e-mail, etc., não existe nenhuma possibilidade de o provedor monitorar o que ali está sendo levado a cabo. Se o fizer, estará interceptando comunicações e violando sigilo. Estaria o provedor tendo comportamento criminoso e danoso, por conseqüência, para quem teve seu e-mail ou chat violado, quando pretendia permanecer em segredo o que ali foi remetido ou discutido. Afinal, é este mesmo o objetivo destes espaços reservados da Internet. Não permitir a imissão de terceiros, nem a revelação de conteúdo do que está
} 
Além disso, outra vantagem desses registros é que mesmo que o cônjuge apague os e-mails ou suma com o computador, a prova permanece. O maior problema será comprovar quem estava "teclando", quem era o usuário, mas esta prova cabe ao cônjuge culpado. ${ }^{264}$

Assim, como visto, é difícil a prova de um relacionamento virtual, mas nãoimpossível, existindo meios que o cônjuge, legitimamente, pode utilizar para provar a infidelidade virtual do consorte. Podemos afirmar que as provas da infidelidade virtual não diferem muito das convencionais, mas "pouquíssimas vezes haverá possibilidade de obter-se uma prova direta e irrefutável. Por isso, recorre-se a presunções, que devem ser graves e de uma veemência intensíssima". ${ }^{265}$ Além disso, "se, na seqüência dos fatos, a prova não tem vigor necessário para atestar o cometimento da infidelidade, pode caracterizar a injúria grave". ${ }^{266}$

Portanto, também nos relacionamentos virtuais podemos encontrar presunções que fundamentam o pedido de divórcio, ${ }^{267}$ e na ausência de provas, as relações suspeitas envolvendo o cônjuge com terceira pessoa podem constituir injúria grave.

Cabe ressaltar que "no espaço virtual as pessoas pensam que estão protegidas, porém este espaço é muito pouco discreto e garante uma privacidade apenas relativa ao internauta. Mesmo que ele se identifique por apelidos (nicks), a correspondência trocada fica armazenada na memória do computador e no provedor de acesso à rede. Este funciona como uma espécie de banco onde ficam armazenadas todas as comunicações virtuais que poderão ser judicialmente requisitadas ou até mesmo invadidas ilegalmente por técnicos. Mesmo que ele use senha para bloquear o acesso ao correio eletrônico, especialistas (hackers e crackers) têm condições de descobri-la. Podem

sendo discutido. $\mathrm{O}$ assunto tratado haverá de permanecer íntegro, sem que terceiros estranhos tenham algum acesso". SANTOS, Antonio Jeová. Dano moral na Internet. São Paulo: Método, 2001. p. 13.

${ }^{264}$ Os dados de conexão são provas que geram presunção apenas relativa de autoria, pois esses registros apenas identificam o computador de onde foi realizado o ato ilícito, e não, necessariamente, a pessoa que o praticou. Nas palavras de Newton De Lucca: "mesmo com a identificação do terminal, não se resolve a questão, pois este pode ser de outra pessoa que não aquela que efetuou a operação. Uma senha ou um código secreto servem para identificar o usuário junto ao provedor, mas não a própria pessoa que tenha efetuado a operação". DE LUCCA, Newton. Títulos e contratos eletrônicos. In: ; SIMÃO FILHO, Adalberto (Coords.). Direito \& Internet: aspectos jurídicos relevantes Bauru: Edipro, 2001. p. 59.

${ }^{265}$ LIMA, Domingos Sávio Brandão. Adultério. cit., p. 464.

${ }^{266} \mathrm{Na}$ incerteza do adultério, o melhor é tender para a injúria que, na realidade, é o rótulo de todos os motivos preestabelecidos para a decretação da separação.

${ }^{267}$ Sendo axiomático que a prova pode fazer-se por quaisquer meios lícitos, raras vezes é possível fazer prova direta. Assim, em regra a prova acaba se fazendo por presunções, através de fatos que permitem concluir a prática da violação do dever de fidelidade. 
ingressar no provedor e, chegando até o arquivo mestre, copiar a senha." ${ }^{268}$ Assim, ainda não existem meios idôneos para garantir plena segurança às comunicações virtuais. Já existe, inclusive, serviços de investigação na Internet para localizar provas da existência ou não da infidelidade virtual. ${ }^{269}$

Provada a infidelidade conjugal pelo autor, ao réu compete o ônus de conseguir provar a sua inexistência, ou que o autor concorreu para que a mesma fosse praticada, ou ainda que, conhecendo-a, já havia perdoado com ele coabitando.

Por fim, é importante relembrar que quando o fato a ser provado é o dano moral, a repercussão do ato ilícito no âmbito da vítima, não é necessária a prova direta sobre isso. $\mathrm{O}$ autor apenas deve fazer prova sobre os demais elementos da responsabilidade civil, como a existência do fato, o nexo causal, e a culpa ou o dolo. Em matéria de dano moral não é possível produzir uma prova direta sobre o prejuízo padecido.

\subsection{Cautelar de Exibição}

O transcurso do tempo exigido pela tramitação processual pode acarretar ou ensejar, e freqüentemente acarreta ou enseja, variações irremediáveis não-só nas coisas como nas pessoas e relações jurídicas substanciais envolvidas no litígio, que, não-obstados, acabam por inutilizar a solução final do processo, em muitos casos. ${ }^{270}$ É intuitivo, destarte, que a atividade jurisdicional tem de dispor de instrumentos e mecanismos adequados para contornar os efeitos deletérios do tempo sobre o processo. ${ }^{271}$

Nas palavras de Humberto Theodoro Júnior: "consiste a ação cautelar no direito de provocar, o interessado, o órgão judicial a tomar providências que conservem e assegurem os elementos do processo (pessoas, provas e bens), eliminando a ameaça de perigo ou prejuizo iminente e irreparável ao interesse tutelado no processo principal." 272

${ }^{268}$ GUIMARÃES, Marilene Silveira. Adultério virtual, infidelidade virtual. In: II CONGRESSO BRASILEIRO DE DIREITO DE FAMÍLIA - IBDFAM. A família na travessia do milênio. Belo Horizonte: Del Rey, 2000. p. 452.

${ }^{269}$ Disponível em: <http://www.investigadoresteam.com/traicao.htm>. Acesso em: 29 ago. 2006.

${ }^{270}$ Nesse sentido, THEODORO JÚNIOR, Humberto. Curso de direito processual civil: processo de execução e processo cautelar. 26. ed. Rio de Janeiro: Forense, 1999. v. 2, p. 360.

271 "Se os órgãos jurisdicionais não contassem com um meio pronto e eficaz para assegurar a permanência ou conservação do estado das pessoas, coisas e provas, enquanto não atingido o estágio último da prestação jurisdicional, esta correria o risco de cair no vazio, ou de transformar-se em provimento inócuo e inútill". THEODORO JÚNIOR, Humberto. Curso de direito processual civil: processo de execução e processo cautelar. 26. ed. Rio de Janeiro: Forense, 1999. v. 2, p. 360.

${ }^{272}$ Id. Ibid., p. 362. 
Ou seja, a ação cautelar consiste no direito de "assegurar que o processo possa conseguir um resultado útil". 273

Assim, "podemos definir a medida cautelar como a providência concreta tomada pelo órgão judicial para eliminar uma situação de perigo para o direito ou interesse de um litigante, mediante conservação do estado de fato ou de direito que envolve as partes, durante todo o tempo necessário para o desenvolvimento do processo principal." 274 Ela é apenas de "prevenção" ou "garantia", porque quem a obtém, mesmo ganhando a ação cautelar, não consegue, só com ela, a satisfação de seu pretenso direito, que continua na dependência da solução do processo principal. ${ }^{275}$ Portanto, o processo principal busca tutelar o Direito, no mais amplo sentido, cabendo ao processo cautelar a missão de tutelar o processo, de modo a garantir que o seu resultado seja eficaz, útil e operante.

Os requisitos para alcançar-se uma providência de natureza cautelar são, basicamente: um dano potencial, um risco que corre o processo principal de não ser útil ao interesse demonstrado pela parte, em razão do periculum in mora, risco esse que deve ser objetivamente apurável; ${ }^{276}$ e a plausibilidade do direito substancial invocado por quem pretenda segurança, ou seja, o fumus boni iuris. ${ }^{277}$

Portanto, "para a ação cautelar, não é preciso demonstrar-se cabalmente a existência do direito material em risco, mesmo porque esse, freqüentemente, é litigioso e só terá sua comprovação e declaração no processo principal. Para merecer a tutela cautelar, o direito em risco há de revelar-se apenas como o interesse que justifica o 'direito de ação', ou seja, o direito ao processo de mérito". ${ }^{278}$ Também não se pode tutelar

${ }^{273}$ LIEBMAN, Enrico Tullio. Manuale di diritto processuale civile. n. 36, 1968. v. 1; apud THEODORO JÚNIOR, Humberto. Curso de direito processual civil: processo de execução e processo cautelar. 26. ed. Rio de Janeiro: Forense, 1999. p. 362.

${ }^{274}$ THEODORO JÚNIOR, Humberto. Curso de direito processual civil: processo de execução e processo cautelar. cit., p. 362-363.

${ }^{275}$ Cf. Id. Ibid., p. 362.

276 "Para obtenção da tutela cautelar, a parte deverá demonstrar fundado temor de que, enquanto aguarda a tutela definitiva, venham a faltar as circunstâncias de fato favoráveis à própria tutela. E isto pode ocorrer quando haja o risco de perecimento, destruição, desvio, deterioração, ou de qualquer mutação das pessoas, bens ou provas necessários para a perfeita e eficaz atuação do provimento final do processo principal”. Id. Ibid., p. 372.

277 "Se, à primeira vista, conta a parte com a possibilidade de exercer o direito de ação e se o fato narrado, em tese, lhe assegura provimento de mérito favorável, presente se acha o fumus boni iuris, em grau suficiente para autorizar a proteção das medidas preventivas". Id. Ibid., p. 372.

${ }^{278}$ THEODORO JÚNIOR, Humberto. Curso de direito processual civil: processo de execução e processo cautelar. cit., p. 371 . 
qualquer interesse, mas tão-somente aqueles que, pela aparência, se mostram plausíveis de tutela no processo principal.

Dessa forma, uma questão processual de grande relevância, relacionada à prova da infidelidade virtual, é a necessidade de o cônjuge inocente, que tiver profunda convicção da infidelidade de seu consorte, para assegurar a sua prova, ${ }^{279}$ ingressar desde já com uma ação cautelar, concomitantemente à ação de separação judicial litigiosa, ou mesmo anteriormente a esta, como uma medida preparatória.

Em função da falta de regulamentação das atividades dos provedores de serviços de Internet, estes podem descartar-se dos registros a qualquer momento. ${ }^{280}$ Sabese que na prática os registros são conservados por em média seis meses. Assim, deve o cônjuge promover, logo no início, uma ação cautelar de exibição de documentos ${ }^{281}$ contra o provedor, para assegurar a manutenção dessa importante prova. É crucial que o cônjuge tome essa medida de precaução logo que entrar com a ação de separação judicial, ou mesmo antes, como uma ação preparatória, já que essa é sua principal prova, em que se fundamenta o litígio. ${ }^{282}$

Caso se espere o trâmite normal da ação de separação judicial litigiosa, que tem levado muitos anos em alguns casos, provavelmente no momento de se realizar a prova da infidelidade virtual, está já terá se perdido. Portanto, no caso da infidelidade virtual, a tutela antecipada se faz necessária para a produção de provas, que em pouco tempo poderá se perder. De qualquer modo, é preciso existir a aparência do bom direito, além do perigo na demora.

Ou seja, dada a natureza peremptória dos registros dos dados de conexão e cadastrais feitos pelos provedores de serviços, deve-se propor com uma cautelar de exibição, baseado no art. 844, incs. I e II, do Código de Processo Civil, ${ }^{283}$ para assegurar a

\footnotetext{
${ }^{279}$ As medidas cautelares para assegurar provas compreendem a antecipação de coleta de elementos de convicção a serem utilizadas na futura instrução do processo principal. Cf. THEODORO JÚNIOR, Humberto. Curso de direito processual civil: processo de execução e processo cautelar. 26. ed. Rio de Janeiro: Forense, 1999. v. 2, p. 367.

${ }^{280}$ A manutenção de tais registros não pode ser perpétua, dado o enorme volume de dados gerado no curso das atividades no sistema, o que implicaria um alto custo de manutenção.

${ }^{281}$ A ação de exibição compreende a pretensão de exigir a exibição em juízo de documento próprio ou comum, em poder de co-interessado, sócio, condômino, credor ou devedor; ou em poder de terceiro que o tenha em sua guarda, como inventariante, testamenteiro, depositário ou administrador de bens alheios.

${ }^{282}$ A exibição pode ser incidente da fase probatória do processo de cognição ou uma medida cautelar preparatória. Nesse sentido, THEODORO JÚNIOR, Humberto. Curso de direito processual civil: processo de execução e cumprimento de sentença, processo cautelar e tutela de urgência. 39. ed. Rio de Janeiro: Forense, 2006. v. 2, p. 582.

283 “Art. 844. Tem lugar, como procedimento preparatório, a exibição judicial:

I - de coisa móvel em poder de outrem e que o requerente repute sua ou tenha interesse em conhecer;
} 
preservação de tais dados, pois caso perdidos inviabilizam a realização da prova. " $O$ que caracteriza a exibição como medida cautelar é servir para evitar o risco de uma ação mal proposta ou deficientemente instruída, tal como ocorre nas antecipações de prova, de maneira geral. Com ela evita-se a surpresa ou o risco de deparar, no curso do futuro processo, com uma situação de prova impossivel ou inexistente". ${ }^{284}$

Trata-se de medida tipicamente satisfativa de um direito subjetivo material, portanto ela não pode reputar-se instrumental a outro processo. A ação cautelar de exibição só é admitida como preparatória de ação principal, como meio de se adquirirem as provas necessárias à sua instrução, ou incidental à própria ação de separação judicial, no curso do processo, neste caso devendo ser requisitada logo no início, para evitar a perda da prova. $^{285}$

Em ambos a ação será proposta contra um terceiro, no caso o provedor de serviços de Internet, que é chamado a colaborar com a instrução do processo. ${ }^{286} \mathrm{~A}$ princípio essa solução parece adequada, uma vez que é afastado o problema da identidade de partes entre a ação cautelar e a ação principal. ${ }^{287}$

A cautelar de exibição não será movida contra o réu da ação, no caso o cônjuge infiel, para que este apresente cópias dos e-mails, por exemplo, pois ele é escusado da exibição da coisa ou documento caso a sua apresentação possa violar dever de honra. Assim, nos casos "em que o documento ou a coisa provaria o adultério de outrem, ou suas relações sexuais clandestinas com alguma pessoa". ${ }^{288}$ Como dito anteriormente, na

II - de documento próprio ou comum, em poder de co-interessado, sócio, condômino, credor ou devedor; ou em poder de terceiro que o tenha em sua guarda, como inventariante, testamenteiro, depositário ou administrador de bens alheios".

Ela fornece elementos de fato que se destinam a instruir o futuro processo, sem se preocupar com a maior ou menor razão daquele que dela se vale, e sem ter um objetivo a exaurir em si mesma, realiza atividade tipicamente cautelar. Cf. THEODORO JÚNIOR, Humberto. Curso de direito processual civil: processo de execução e cumprimento de sentença, processo cautelar e tutela de urgência. 39. ed. cit., p. 584.

${ }^{284}$ THEODORO JÚNIOR, Humberto. Curso de direito processual civil: processo de execução e cumprimento de sentença, processo cautelar e tutela de urgência. 39. ed. cit., p. 583.

285 "O direito à exibição tende à constituição ou asseguração de prova, ou às vezes ao exercício de um simples direito de conhecer e fiscalizar o objeto em poder de terceiro. Não visa a ação de exibição a privar o demandado da posse de bem exibido, mas apenas a propiciar ao promovente o contato físico direto, visual, sobre a coisa". Id. Ibid., p. 582.

${ }^{286}$ A cautelar de exibição pode ser proposta também contra terceiros, pois o Código atribui a eles o ônus de cooperar para a distribuição da justiça e conseqüentemente para a descoberta da verdade.

${ }^{287}$ Parte da doutrina e jurisprudência entende não ser recomendável a propositura de ação cautelar inominada com o mesmo objetivo, uma vez que as partes no feito principal devem ser as mesmas da ação cautelar, o que não ocorre nestes casos, em que a providência solicitada ao provedor de serviços não guarda relação direta com a ação principal a ser movida pela vítima do ato ilícito.

${ }^{288}$ THEODORO JÚNIOR, Humberto. Curso de direito processual civil: processo de execução e cumprimento de sentença, processo cautelar e tutela de urgência. 39. ed. cit., p 587. 
hipótese por nós apresentada, a cautelar é movida contra o provedor pois é ele quem detém os dados de conexão, que serão utilizados como provas.

Portanto, em princípio, a propositura de ação cautelar de exibição é necessária, objetivando seja o provedor de serviços compelido a exibir em Juízo os dados cadastrais e de conexão de um usuário. Alguns autores discutem a necessidade de que o documento seja próprio ou comum, ${ }^{289}$ mas outros entendem que é admitida a ação exibitória toda vez que o Autor necessitar de documento em posse de terceiro.

Dessa forma, concluímos: "tão premente se apresenta em tema de Direito de Família a solução rápida do litígio, por envolver esse ramo do Direito, em regra, valores sensivveis e de grande significado emocional, às vezes materiais, vinculados à realização de necessidades íntimas do ser humano, que exige no plano processual uma pronta resposta da jurisdição". 290

\section{Conclusão}

Conforme adverte Álvaro Villaça Azevedo: “o Direito de Família é evolutivo, porque à medida que passa o tempo, os homens passam sobre a terra, os costumes mudam, os entendimentos se transformam e as coisas tomam novos coloridos, segundo o prisma enfático de quem observa". ${ }^{291}$

A infidelidade, como se disse, sempre existiu e continuará existindo. A prática é que vai variando ao longo do tempo, sendo que uma das mais recentes formas de infidelidade conjugal é aquela que se estabelece através da Internet. Surge o que podemos chamar, numa espécie de neologismo, de "e-infidelidade". Assim, a infidelidade virtual começa a tomar espaço na doutrina brasileira como uma novidade do Direito de Família. A partir dessa nova realidade cibernética, os ordenamentos jurídicos terão que rediscutir e reformular alguns de seus conceitos.

Sejam favoráveis ou contrários à Internet, ninguém pode ficar indiferente a ela. De uma forma ou de outra, a Internet é muito presente na vida dos cidadãos. Com a sua

\footnotetext{
${ }^{289}$ Nas palavras de Humberto Theodoro Júnior: “documento comum não é, assim, apenas o que pertence indistintamente a ambas as partes, mas também o que se refere a uma situação jurídica que envolva ambas as partes, ou uma das partes e terceiro". THEODORO JÚNIOR, Humberto. Curso de direito processual civil: processo de execução e cumprimento de sentença, processo cautelar e tutela de urgência. 39. ed. Rio de Janeiro: Forense, 2006. v. 2, p 585.

${ }^{290}$ OLIVEIRA, Carlos Alberto Álvaro de. A urgência e o direito de família (as chamadas medidas provisionais do artigo 888 do CPC). In: II CONGRESSO BRASILEIRO DE DIREITO DE FAMÍLIA - IBDFAM. A família na travessia do milênio. Belo Horizonte: Del Rey, 2000. p. 427-437.

${ }^{291}$ AZEVEDO, Álvaro Villaça. Dever de coabitação: inadimplemento. 1976. Tese (Livre-Docência) - Faculdade de Direito, Universidade de São Paulo, São Paulo. p. 296.
} 
popularização aumentaram os problemas jurídicos dela decorrentes, atingindo inclusive os relacionamentos. Evidente que não é a Internet que estraga os relacionamentos, mas ela potencializa o dano. Na prática, vários casais já experimentaram os sabores e dissabores dessas novas relações.

Portanto, não trazer essa discussão, é deixar de fora do universo jurídico essa realidade, que se torna cada dia mais freqüente. Ignorá-la é omitir o cumprimento das funções jurídicas de tentar colocar limites e barrar um gozo cujo excesso pode ser inviabilizador das diversas relações.

Acreditamos ter atingido nosso objetivo inicialmente exposto, porém, este assunto há que ser analisado com muita parcimônia, já que, como visto, ainda há entendimentos conflitantes. Por isso, concluímos que o tema é por demais instigante e carece de maiores estudos. Sendo a infidelidade virtual ainda, uma incógnita, convém aprofundar o debate para se chegar a um julgamento justo dessa nova realidade.

Por fim, podemos dizer que não há um padrão ideal de fidelidade. Está no âmbito subjetivo das pessoas aquilo que elas esperam de seu cônjuge ou companheiro, bem como os atos por eles praticados que tornam insuportável a vida em comum. Entretanto, o problema é evidente: o uso da Internet já se tornou um dos assuntos inevitáveis na vida de um casal. Trata-se de uma realidade nada virtual.

Por isso afirmamos categoricamente que a infidelidade virtual "é uma realidade, e tem efeitos jurídicos".

São Paulo, setembro de 2006.

\section{Referências}

ABREU, José. O divórcio no direito brasileiro. 2. ed. São Paulo: Saraiva, 1992.

ACQUAVIVA, Marcus Cláudio. Dicionário acadêmico de direito. São Paulo: Jurídica Brasileira, 1999.

ANDREUCCI, Ricardo Antunes. Da incriminação do adultério. 1967.

AULETE, Caldas. Dicionário contemporâneo de língua portuguesa. 3. ed. Rio de Janeiro: Delta, 1978. v. 1 e 3.

AVOLIO, Luiz Francisco Torquato. Provas ilícitas. interceptações telefônicas, ambientais e gravações clandestinas. 3. ed. São Paulo: Revista dos Tribunais, 2003.

AZEVEDO, Álvaro Villaça. Estatuto da família de fato. 2. ed. São Paulo: Atlas, 2002. 
. Teoria geral das obrigações. 7. ed. São Paulo: Revista dos Tribunais, 1999.

. Dever de coabitação: inadimplemento. Tese de Livre Docência USP. São Paulo, 1976.

AZEVEDO, Álvaro Villaça; VENOSA, Silvio de Salvo. Código civil anotado e legislação complementar. São Paulo: Atlas, 2003.

BARBOSA, José Olindo Gil. As provas ilícitas no processo brasileiro. Disponível em $<$ http://jus2. uol.com.br/doutrina/texto.asp?id=8417>. Acesso em: 05 jun. 2006.

BELINCANTA, Fernando César; LOPES, Fernando Augusto Monati y. A possibilidade da compensação do dano moral na separação conjugal. Disponível em: <http://jus2.uol.com.br/ doutrina/texto.asp?id=3743>. Acesso em: 29 ago. 2006.

BEVILAQUA, Clóvis. Código civil. 10. ed. Rio de Janeiro: Francisco Alves, 1954. t. II.

BITTAR, Carlos Alberto. Reparação civil por danos morais. São Paulo: Revista dos Tribunais, 1993.

BITTENCOURT, Edgard de Moura. Família. Rio de Janeiro: Alba. 1995.

BRITTO, Gabriel de Lemos. Psychologia do adultério. Rio de Janeiro: Livraria Jacintho, 1933.

BRASIL, Ângela Bittencourt. O adultério na internet. Disponível em: < http://www1.jus.com.br/ doutrina/imprimir.asp?id=1832>, <http://www.advogado.com/internet/zip/adulterio.htm $>$. Acesso em: 17 maio 2005.

BUENO, Francisco da Silveira. Grande dicionário etimológico-prosódico da língua portuguesa. São Paulo: Saraiva, 1963. v. 1 e 4.

CAHALI, Yussef Said. Adultério e desquite. 1972. Tese (Livre-Docência) - Faculdade de Direito, Universidade de São Paulo, São Paulo.

. Divórcio e separação. 10. ed. São Paulo: Revista dos Tribunais, 2002.

. Divórcio e separação. 11. ed. São Paulo: Revista dos Tribunais, 2005.

CARLOMAGNO, Fernando. Aspectos penais e civis da infidelidade virtual. Disponível em: < http:// www.direitonet.com.br/artigos/x/17/88/1788/>. Acesso em: 29 maio 2006.

CARNEIRO, Alaim de Almeida. Adultério. In: SANTOS, J. M. de Carvalho. Repertório Enciclopédico do Direito Brasileiro. Rio de Janeiro: Borsoi, 1947. v. 2. 
COLARES, Marcos. Onde mora a (in)fidelidade? In: NAZARETH, Eliana Riberti; MOTTA, Maria Antonieta Pisano. (Coords.). Direito de família e ciências humanas: caderno de estudos n. 2. São Paulo: Jurídica Brasileira, 1998. p. 183-196.

. O que há de novo no direito de família? In: II CONGRESSO BRASILEIRO DE DIREITO DE FAMÍLIA - IBDFAM. A família na travessia do milênio. Belo Horizonte: Del Rey, 2000. p. 315-323.

COLTRO, Antonio Carlos Mathias; FIGUEIREDO, Sálvio de; MAFRA, Tereza Cristina Monteiro. Comentários ao novo código civil: do direito pessoal. Rio de Janeiro: Forense, 2005. v. 17.

COMTE-SPONVILLE, André. Pequeno tratado das grandes virtudes. São Paulo: Martins Fontes, 1999.

COMTE-SPONVILLE, André. Pequeno tratado das grandes virtudes. Tradução de Eduardo Brandão. Disponível em: <http://br.geocities.com/mcrost04/pequeno_tratado_das_grandes_ virtudes_03.htm>.Acesso em: 17 maio 2005 .

COSTA, Carlos Celso Orcesi da. Tratado do casamento e do divórcio, constituição, invalidade, dissolução. São Paulo: Saraiva, 1987. v. 2.

COSTA, Gley P. A cena conjugal. Porto Alegre: Artmed, 2000.

CRISPINO, Nicolau Eládio Bassalo. Responsabilidade civil dos conviventes. In: II CONGRESSO BRASILEIRO DE DIREITO DE FAMÍLIA - IBDFAM. A família na travessia do milênio. Belo Horizonte: Del Rey, 2000. p. 105-120.

DAOUN, Alexandre Jean. O adultério virtual. Disponível em: <http://jus2.uol.com.br/doutrina/ texto.asp?id=2564>. Acesso em: 29 maio 2006.

DELMANTO, Magalhães. Comentários ao código penal. Rio de Janeiro: Forense, 1944. v. 9.

DE LUCCA, Newton. Títulos e contratos eletrônicos. In: DE LUCCA, Newton; SIMÃO FILHO, Adalberto. (Coords.). Direito \& Internet: aspectos jurídicos relevantes. Bauru: Edipro, 2001.

DIAS, Maria Berenice. O dever de fidelidade. Disponível em: <http://www.mundojuridico.adv. br/html/artigos/documentos/texto224.htm ou <http:/editorial.locaweb.com.br/Seu Direito/Artigos/ o_dever_de_fidelidade.htm>. Acesso em: 16 maio 2005.

. Era uma vez... . In: IV CONGRESSO BRASILEIRO DE DIREITO DE FAMÍLIA IBDFAM. Afeto, ética, família e o novo código civil. Belo Horizonte: Del Rey, 2004. p. 13-16.

DINIZ, Maria Helena. Código civil anotado. 3. ed. São Paulo: Saraiva, 1997. 
. Curso de direito civil brasileiro: direito de família. 17. ed. São Paulo: Saraiva, 2002. v. 7.

. Curso de direito civil brasileiro. São Paulo: Saraiva, 1993. v. 7.

. Dicionário jurídico. São Paulo: Saraiva, 1998. v. 1 e 2.

DONZELE, Patrícia Fortes Lopes. Prova ilícita. Disponível em: <http://www.direitonet.com.br/ $\operatorname{artigos} / \mathrm{x} / 14 / 95 / 1495 />$. Acesso em: 05 jun. 2006.

FACHIN, Luiz Edson; RUZYK, Carlos Eduardo Pianovski. Código civil comentado: direito de família - casamento. São Paulo: Atlas, 2003. v. 15.

FARIA, Bento de. Código penal brasileiro. 2. ed. Rio de Janeiro: Record, 1959.v. 6.

FARIAS, Cristiano Chaves de. Redesenhando os contornos da dissolução do casamento (Casar e permanecer casado: eis a questão). In: IV CONGRESSO BRASILEIRO DE DIREITO DE FAMÍLIA - IBDFAM. Afeto, ética, família e o novo código civil. Belo Horizonte: Del Rey, 2004. p. 105-126.

FERRAZ JUNIOR, Tercio Sampaio. Introdução ao estudo do direito: técnica, decisão, dominação. 3. ed. São Paulo: Atlas, 2001.

FERREIRA, Aurélio Buarque de Holanda. Novo dicionário da língua portuguesa. 2. ed., 13. impr. Rio de Janeiro: Nova Fronteira, 1986.

FIUZA, César Augusto de Castro. Mudança de paradigmas: do tradicional ao contemporâneo. In: IV CONGRESSO BRASILEIRO DE DIREITO DE FAMÍLIA - IBDFAM. Afeto, ética, família e o novo código civil. Belo Horizonte: Del Rey, 2004. p. 27-38.

FRAGA, Antonio Celso Galdino. Crimes de informática: a ameaça virtual na era da informação digital. In: INTERNET: o direito na era virtual. 2. ed. Rio de Janeiro: Forense, 2001.

FRAGOSO, Heleno Cláudio. Lições de direito penal. 3. ed. Rio de Janeiro: Forense, 1981. v. 3.

FREIRE, Laudelino. Grande e novíssimo dicionário da língua portuguesa. 3. ed. Rio de Janeiro: Livraria José Olympio, 1957. v. 1.

FUNK \& WAGNALLS. Britannica World Language Dictionary. Chicago, New York, 1963. v. 1, parte 1 .

GARCIA, Carolina Ribeiro. O dever de fidelidade no casamento e na união estável e suas possíveis conseqüências. Disponível em: <http://www1.jus.com.br/doutrina/imprimir.asp?id=5222>. Acesso em: 16 maio 2005.

GOMES, Orlando. Direito de família. 12. ed. Rio de Janeiro: Forense, 2000. 
GONÇALVES, Carlos Roberto. Sinopses jurídicas: direito de família. 10. ed. São Paulo: Saraiva, 2005. v. 2.

GRINOVER, Ada Pellegrini. As nulidades no processo penal. 6. ed. São Paulo: Revista dos Tribunais, 2000.

GROENINGA, Giselle Câmara. Direito e psicanálise: um novo horizonte epistemológico. In: IV CONGRESSO BRASILEIRO DE DIREITO DE FAMÍLIA - IBDFAM. Afeto, ética, família e o novo código civil. Belo Horizonte: Del Rey, 2004. p. 249-263.

GUIMARÃES, Marilene Silveira. Adultério virtual, infidelidade virtual. In: II CONGRESSO BRASILEIRO DE DIREITO DE FAMÍLIA - IBDFAM. A família na travessia do milênio. Belo Horizonte: Del Rey, 2000. p. 439-454.

HOUAISS, Antonio. Dicionário Houaiss da língua portuguesa. 1. ed. Rio de Janeiro: Objetiva, 2001.

HUNGRIA, Nelson; LACERDA, Romão Cortês de; FRAGOSO, Heleno C. Comentários ao código penal. 5. ed. Rio de Janeiro: Forense, 1981. v. 8.

KELSEN, Hans. Teoria pura do direito. São Paulo: Martins Fontes, 2000.

KOSOVSKI, Éster. O crime de adultério. Rio de Janeiro: Mauad, 1997.

LAWAND, Jorge José. $O$ direito de família e a produção de provas. Disponível em: $<$ http://www. boletimjuridico.com.br/doutrina/impressao.asp?id=544>. Acesso em: 29 maio 2006.

LEVENHAGEM, Antonio José de Souza. Do casamento ao divórcio. 11. ed. São Paulo: Atlas, 1999.

LEONARDI, Marcel. Responsabilidade civil dos provedores de serviços de internet. São Paulo: Juarez de Oliveira, 2005.

LIMA, Domingos Sávio Brandão. Adultério, a mais infamante causa de divórcio. São Paulo: L. Oren, 1976.

. Adultério. In: FRANÇA, Rubens Limongi (Coord.). Enciclopédia Saraiva do Direito. São Paulo: Saraiva, 1977. v. 4, p. 448-470.

MADALENO, Rolf. Direito de família: aspectos polêmicos. Porto Alegre: Livraria do Advogado, 1998. 
. A infidelidade e o mito causal da separação. Disponível em: $<$ http://editorial.locaweb.com. br/SeuDireito/Artigos/a_infidelidade_eo_mito_causal.htm>. Acesso em: 17 maio 2005.

MIRABETE, Julio Fabbrini. Manual de direito penal. 14. ed. São Paulo: Atlas, 2000. v. 3.

MIRANDA, Francisco Cavalcanti Pontes de. Tratado de direito privado. Rio de Janeiro: Borsoi, 1955. v. 8 .

MONTEIRO, Washington de Barros. Curso de direito civil. 34. ed. São Paulo: Saraiva, 1997. v. 2.

MORAES, Maria Celina Bodin. Danos morais e relações de família. In: IV CONGRESSO BRASILEIRO DE DIREITO DE FAMÍLIA - IBDFAM. Afeto, ética, família e o novo código civil. Belo Horizonte: Del Rey, 2004. p. 399-415.

MOTTA, Maria Antonieta Pisano. Além dos fatos e dos relatos: uma visão psicanalítica do direito de família. In: II CONGRESSO BRASILEIRO DE DIREITO DE FAMÍLIA - IBDFAM. A família na travessia do milênio. Belo Horizonte: Del Rey, 2000. p. 39-52.

MURRAY, James A. H.; BRADLEY, Henry. The Oxford English Dictionary, Oxford, v. I, 1933.

NORONHA, Magalhães de. Direito penal. 15. ed. São Paulo: Saraiva, 1978. v. 3.

OLIVEIRA, Carlos Alberto Alvaro de. A urgência e o direito de família (as chamadas medidas provisionais do artigo 888 do CPC). In: II CONGRESSO BRASILEIRO DE DIREITO DE FAMÍLIA - IBDFAM. A família na travessia do milênio. Belo Horizonte: Del Rey, 2000. p. 427-437.

OLIVEIRA, Euclides Benedito de. Efeitos materiais da separação judicial e do divórcio. In: II CONGRESSO BRASILEIRO DE DIREITO DE FAMÍLIA - IBDFAM. A família na travessia do milênio. Belo Horizonte: Del Rey, 2000.p. 71-92.

PARERAS, Luis G. Internet y derecho. Barcelona: Masson, 1998.

PELUSO, Antonio Cezar. A culpa na separação e no divórcio: contribuição para uma revisão legislativa. In: NAZARETH, Eliana Riberti; MOTTA, Maria Antonieta Pisano (Coords.). Direito de família e ciências humanas: Caderno de Estudos. São Paulo: Jurídica Brasileira, 1998. n. 2, p. 41-58.

PENTEADO, Jacques de Camargo. A família e a justiça penal. In: II CONGRESSO BRASILEIRO DE DIREITO DE FAMÍLIA - IBDFAM. A família na travessia do milênio. Belo Horizonte: Del Rey, 2000. p. 353-363.

PEREIRA, Caio Mário da Silva. Instituições de direito civil: direito de família. 14. ed. Rio de Janeiro: Forense, 2004. v. 5. 
PEREIRA, Rodrigo da Cunha. Adultério virtual. Disponível em: $<$ http://www.boletimjuridico.com. br/doutrina/impressao.asp?id=154>. Acesso em: 29 maio 2006.

PEREIRA, Rodrigo da Cunha. A culpa no desenlace conjugal. n: NAZARETH, Eliana Riberti; MOTTA, Maria Antonieta Pisano (Coords.). Direito de família e ciências humanas: Caderno de Estudos. São Paulo: Jurídica Brasileira, 1998. n. 3, p. 133-153.

PEREIRA NETO, Miguel. Os documentos eletrônicos utilizados como meio de prova para a constituição de titulo executivo extrajudicial e judicial. In: Internet: o direito na era virtual. 2. ed. Rio de Janeiro: Forense, 2001.

PINTO, Fernando Brandão Ferreira. Causas do divórcio. Coimbra: Livraria Almedina, 1980.

PINTO, Lino Eduardo Araújo. Infidelidade conjugal e a traição ao alcance de todos. Disponível em: <http://www.ciglioniconsultoria.com.br/mostraartigo.asp?id=11>. Acesso em: 17 maio 2005.

PITTMAN, Frank. Mentiras privadas. Porto Alegre: Artes Médicas, 1994.

REVISTA VEJA. Traição virtual: a nova modalidade de infidelidade é pela internet - e tumultua a vida dos casais. ed. 1.940, ano 39, n. 3. São Paulo: Abril, 2006.

RIBEIRO, Renato Janine. A família na travessia do milênio. In: II CONGRESSO BRASILEIRO DE DIREITO DE FAMÍLIA - IBDFAM. A família na travessia do milênio. Belo Horizonte: Del Rey, 2000. p. 15-24.

RIZZARDO, Arnaldo. Direito de família. 2. ed. Rio de Janeiro: Forense, 2004.

. Separação e Divórcio. In: Direito de família contemporâneo. Belo Horizonte: Del Rey, 1997.

RODRIGUES, Silvio. Comentários ao código civil: do direito de família. São Paulo: Saraiva, 2003. v. 17.

. Direito civil: direito de família. 28. ed. São Paulo: Saraiva, 2004. v. 6.

SALVAT. Diccionario Enciclopédico Salvat. 2. ed., Tomo I. Barcelona: Salvat,1945.

SANTOS, Antonio Jeová. Dano moral na internet. São Paulo: Método, 2001.

SANTOS, Regina Beatriz Tavares da Silva Papa dos. Reparação civil na separação e no divórcio. São Paulo: Saraiva, 2001. 
. Responsabilidade civil dos cônjuges. In: II CONGRESSO BRASILEIRO DE DIREITO DE FAMÍLIA - IBDFAM. A família na travessia do milênio. Belo Horizonte: Del Rey, 2000. p. 121-140.

SCHOUERI, Luís Eduardo. Internet: o direito na era virtual. 2. ed. Rio de Janeiro: Forense, 2001.

SILVA, Denis Cortiz da. Do adultério virtual. Disponível em: <http://jus2.uol.com.br/doutrina/ texto.asp?id=6973>. Acesso em: 29 maio 2006.

SILVA, Hugo Lança. O direito de família e a internet: infidelidade virtual: mito ou realidade com efeitos jurídicos. Lisboa: Verbo Jurídico, 2005.

SILVA, Regina Beatriz Tavares da. A culpa nas relações de família. In: DELGADO, Mário Luiz; ALVES, Jones Figueiredo (Coords.). Questões controvertidas no direito de família e das sucessões. São Paulo: Método, 2005. (Série Grandes Temas de Direito Privado). p. 67-103.

. Débito Conjugal. In: IV CONGRESSO BRASILEIRO DE DIREITO DE FAMÍLIA IBDFAM. Afeto, ética, família e o novo código civil. Belo Horizonte: Del Rey, 2004. p. 531-541. . Novo código civil comentado. São Paulo: Saraiva, 2002.

SILVA, Regina Beatriz Tavares da. Recusa ao sexo pode gerar indenização. Disponível em: <http:// www1.folha.uol.com.br/folha/brasil/ult96u27922.shtml>. Acesso em: 17 maio 2005.

SILVA, Sônia Maria Teixeira da. Traição e dano moral. Disponível em: <http://www.direitovirtual. com.br/print/print.php?page=artigos\&id=165>. Acesso em: 29 maio 2006.

SOARES, Orlando. Direito de família. Rio de Janeiro: Forense, 2004.

TELLES JUNIOR, Goffredo. Palavras do amigo: aos estudantes de direito. São Paulo: Juarez de Oliveira, 2003.

TEPEDINO, Gustavo. O Papel da Culpa na Separação e no Divórcio. In: I CONGRESSO BRASILEIRO DE DIREITO DE FAMÍLIA - IBDFAM. Repensando o direito de família. Belo Horizonte: Del Rey, 1999. p. 191-206.

THEODORO JÚNIOR, Humberto. Curso de direito processual civil: processo de execução e cumprimento de sentença, processo cautelar e tutela de urgência. 39. ed. Rio de Janeiro: Forense, 2006. v. 2.

. Curso de direito processual civil: processo de execução e processo cautelar. 26. ed. Rio de Janeiro: Forense, 1999. v. 2. 
. Processo cautelar. 11. ed. São Paulo: Universitária de Direito, 1989.

VENOSA, Sílvio de Salvo. Direito civil: direito de família. 3. ed. São Paulo: Atlas, 2003. v. 6.

VIEIRA, Tereza. Adultério virtual e infidelidade conjugal na internet. Disponível em: $<$ http://www. unitoledo.br/intertemas>. Acesso em: 29 maio 2006.

WALD, Arnoldo. O novo direito de família. 14. ed. São Paulo: Saraiva, 2002.

ZINGARELLI, Nicola. Il nuovo Zingarelli: vocabolario della língua italiana. 11. ed. Bologna: Zanichelli. 1990. 